ISSN 2616-9983

МІНІСТЕРСТВО ЮСТИЦІЇ УКРАЇНИ АКАДЕМІЯ ДЕРЖАВНОЇ ПЕНІТЕНЦАРНОЇ СЛУЖБИ

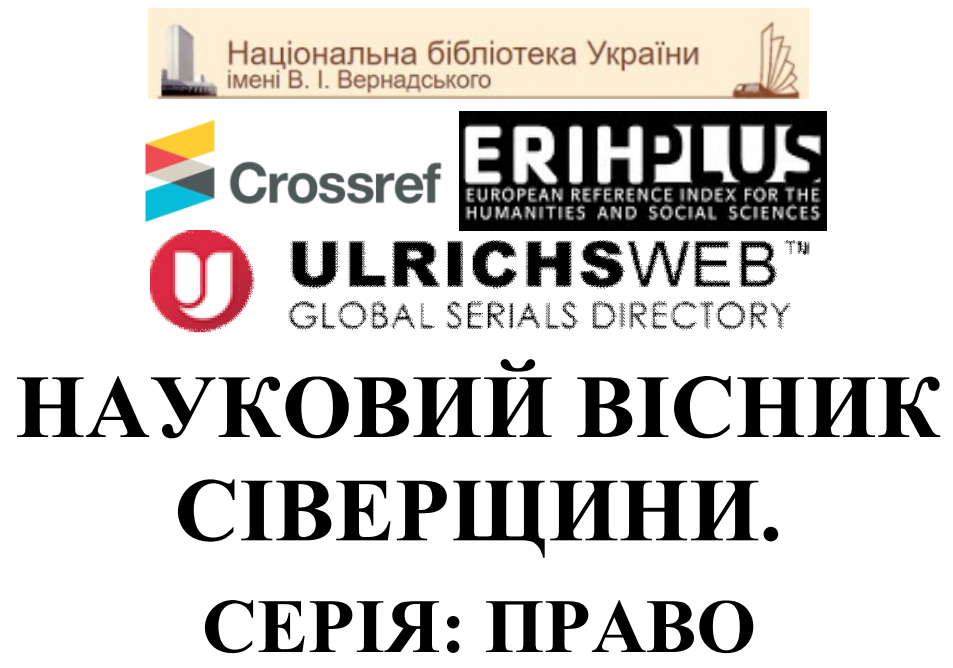

НАУКОВИЙ ЖУРНАЛ

№ 2 (10)

Чернігів 2020 
УДК $34(051)(477)$

$\mathrm{H} 34$

DOI 10.32755/sjlaw.2020.02

Рекомендовано до друку вченою радою Академії Державної пенітенціарної служби (протокол № 15 від 01 грудня 2020 р.).

Науковий вісник Сіверщини. Серія: Право: науковий журнал / Академія

H34 Державної пенітенціарної служби. Чернігів: Академія ДПтС, 2020. № 2 (10). $104 \mathrm{c}$.

У цьому номері журналу «Науковий вісник Сіверщини. Серія: Право» вміщено статті, присвячені загальним проблемам теорії та історії держави і права, філософії права; питанням конституційного та міжнародного права; проблемам цивільного, господарського, соціального та трудового права; актуальним питанням адміністративного, фінансового та інформаційного права; кримінального права, кримінології, кримінально-виконавчого права; теорії і практиці кримінально-процесуальної діяльності та криміналістики, оперативно-розшуковій діяльності. Видання буде корисним для науковців, аспірантів, магістрантів та студентів закладів вищої освіти.

УДК 34(051)(477)

ГОЛОВА РЕДАКЦІЙНО-ВИДАВНИЧОЇ РАДИ:

Тогочинський О.М., д-р пед. наук, проф., ректор Академії Державної пенітенціарної служби, заслужений працівник освіти України.

ГОЛОВНИЙ РЕДАКТОР: Ніщимна С.О., Д-р юрид. наук, проф.

ЗАСТУПНИКИ ГОЛОВНОГО РЕДАКТОРА: Пузирьов М.С., д-р юрид. наук;

Олійник О.І., канд. юрид. наук, доцент.

РЕДАКЦІЙНА КОЛЕГІЯ:

Aндріяшко М.B., канд. юрид. наук, доцент, доцент кафедри загальноправових дисциплін та державного управління, Барановичський державний університет (м. Барановичи, Республіка Білорусь);

Карелін В.В., д-р юрид. наук;

Коломієць Н.В., д-р юрид. наук, доцент,

Коропатник I.M., д-р юрид. наук;

олефір Л.І., канд. юрид. наук;

Партенадзе О.А., д-р права, проф., керівник департаменту права та публічного управління, факультет юридичних та соціальних наук, Батумський державний університет імені Шота Руставелі (м. Батумі, Республіка Грузія);

Скаков А.Б., д-р юрид. наук, проф., професор кафедри кримінально-правових дисциплін, Євразійський національний університет імені Л.М. Гумільова (м. Нур-Султан, Республіка Казахстан);

Солнцева X.B., канд. юрид. наук, доцент;

Taziєв C.P., д-р юрид. наук, заслужений юрист України;

Чумак В.B., д-р юрид. наук, доцент;

Шевчук О.М., канд. юрид. наук;

Шумна Л.П., д-р юрид. наук, доцент.

ВІДПОВІДАЛЬНИЙ СЕКРЕТАР: Сикал М.М., канд. юрид. наук.

Заснований у 2017 році. Свідоцтво про державну реєстрацію: КВ № 22779-12669Р від 14.06.2017
(C) Академія Державної пенітенціарної служби, 2020 
ISSN 2616-9983

\section{MINISTRY OF JUSTICE OF UKRAINE}

ACADEMY OF THE STATE PENITENTIARY

SERVICE

\section{SCIENTIFIC HERALD OF SIVERSHCHYNA. SERIES: LAW}

SCIENTIFIC JOURNAL

№ 2 (10)

Chernihiv 2020 
UDC 34(051)(477)

DOI 10.32755/sjlaw.2020.02

Recommended for printing by Academic Council of Academy of the State Penitentiary Service (Protocol № 15 on December 01, 2020).

Scientific Herald of Sivershchyna. Series: Law: Scientific Journal / Academy of the State Penitentiary Service. Chernihiv: Academy of the SPS, 2020. № 2 (10). $104 \mathrm{p}$.

In this issue of the journal "Scientific Herald of Sivershchyna. Series: Law" the articles, dedicated to general problems of State and Law Theory and History, Philosophy of Law; issues of Constitutional and International Law; the problems of Civil, Business, Social and Industrial Law; current issues of Administrative, Financial and Informational Law; Criminal Law, Criminology, Criminal and Executive Law; theory and practice of Criminalistics and activities of criminal procedure, law enforcement intelligence-gathering activities. The issue will be useful for scientists, postgraduates, masters and the students of higher educational establishments.

UDC 34(051)(477)

\section{PRESIDENT OF EDITORIAL AND PUBLISHING COUNCIL:}

Tohochynskyi O.M., Doctor of Sciences (Pedagogy), Professor, Rector of the Academy of the State Penitentiary Service, Honored Worker of Education of Ukraine.

EDITOR-IN-CHIEF: Nishchymna S.O., Doctor of Sciences (Law), Professor.

DEPUTY EDITOR-IN-CHIEF: Puzyrov M.S., Doctor of Sciences (Law);

Oliinyk O.I., Ph.D. in Law, Associate Professor.

EDITORIAL BOARD:

Andriiashko M.V., PhD in Law, Associate Professor, Associate Professor of the Department of General Legal Disciplines and Public Administration, Baranovichi State University (Baranovichi, Republic of Belarus)

Karelin $\boldsymbol{V} . \boldsymbol{V}$., Doctor of Sciences (Law);

Kolomiets N.V., Doctor of Sciences (Law); Associate Professor;

Koropatnyk I.M., Doctor of Sciences (Law);

Olefir L. I., Ph.D. in Law;

Partenadze O.A., Doctor of Sciences (Law), Professor, Head of the Department of Law and Public Administration, Faculty of Law and Social Sciences, Batumi Shota Rustaveli State University (Batumi, Republic of Georgia);

Skakov A.B, Doctor of Sciences (Law), Professor, Professor of the Department of Criminal Law Disciplines, L.N. Gumilyov Eurasian national university (Nur-Sultan, Republic of Kazakhstan)

Solntseva Kh.V., Ph.D. in Law, Associate Professor;

Tagiev S.R., Doctor of Sciences (Law), Honored Lawyer of Ukraine;

Chumak V.V., Doctor of Sciences (Law), Associate Professor;

Shevchuk O.M., Ph.D. in Law;

Shumna L.P., Doctor of Sciences (Law), Associate Professor.

RESPONSIBLE SECRETARY OF EDITORIAL BOARD: Sykal M.M., Ph.D. in Law.

Founded in 2017. Certificate of state registration:

Series KV № 22779-12669R dated 14.06.2017
(C) Academy of the State

Penitentiary Service, 2020 


\section{MICT}

\section{ЗАГАЛЬНІ ПРОБЛЕМИ ТЕОРІЇ ТА ІСТОРІЇ ДЕРЖАВИ І ПРАВА, ФІЛОСОФІЯ ПРАВА. КОНСТИТУЦІЙНЕ ТА МІЖНАРОДНЕ ПРАВО}

Коба О. В., Коба М. М. Формування правової культури курсантів Національної гвардії України у процесі професійної підготовки 7

Любич $\boldsymbol{C}$. В. Моделі державної служби в європейській спільноті

\section{ПРОБЛЕМИ ЦИВІЛЬНОГО, ГОСПОДАРСЬКОГО, СОЦІАЛЬНОГО ТА ТРУДОВОГО ПРАВА}

Нішцмна С. О., Зливко С. В., Сикал М. М. Споживчі товариства як організаційно-правова форма юридичної особи 28

Шамрук Н. Б., Кульок Д. М. Щодо особистих немайнових та майнових прав і обов'язків батьків та дітей у законодавстві України.

\section{АКТУАЛЬНІ ПИТАННЯ АДМІНІСТРАТИВНОГО, ФІНАНСОВОГО ТА ІНФОРМАЦІЙНОГО ПРАВА}

Ребкало М. М., Шумна Л. П., Олійник В. С. Форми підвищення кваліфікації персоналу Державної кримінально-виконавчої служби України: переваги та недоліки

Ткаченко О. Г., Разумейко Н. С. Поняття та характерні риси конфлікту інтересів під час проходження державної служби в Україні.

\section{КРИМІНАЛЬНЕ ПРАВО, КРИМІНОЛОГІЯ, КРИМННАЛЬНО-ВИКОНАВЧЕ ПРАВО}

Афанасенко А. С., Кондратов Д. Ю., Боднар І. В. Перекриття каналів надходження до засуджених заборонених предметів як протидія пенітенціарній злочинності

Самофалов Л. П., Самофалов О. Л. Проблеми правового регулювання боротьби з тероризмом та запобігання терористичним актам.

\section{ТЕОРІЯ І ПРАКТИКА КРИМІНАЛЬНО-ПРОЦЕСУАЛЬНОӤ ДІЯЛЬНОСТІ ТА КРИМННАЛІСТИКИ. ОПЕРАТИВНО-РОЗШУКОВА ДІЯЛЬНІСТЬ}

Леоненко О. А., Ссипенко О. Г., Рахільчук І. В. Сучасні правові та організаційні засади розвитку судової експертизи під час розслідування злочинів. 


\section{CONTENT}

\section{GENERAL PROBLEMS OF THEORY AND HISTORY \\ OF STATE AND LAW, PHILOSOPHY OF LAW. CONSTITUTIONAL AND INTERNATIONAL LAW}

Koba $\boldsymbol{O}$., Koba M. Formation of legal culture of cadets of the National guard of Ukraine in professional training process ...

Liubych $S$. Public service models in european community

PROBLEMS OF CIVIL, ECONOMIC, SOCIAL AND LABOUR LAW

Nishchymna S., Zlyvko S., Sykal M. Consumer partnerships as organizational and legal form of a juridical entity.....

Shamruk N., Kuliok D. On personal non-property and property rights and responsibilities of parents and children in legislation of Ukraine.

\section{TOPICAL ISSUES OF ADMINISTRATIVE, FINANCIAL AND INFORMATION LAW}

Rebkalo M., Shumna L., Oliinyk V. Forms of personnel advanced development of criminal and executive service of Ukraine: advantages and disadvantages

Tkachenko O., Razumeiko $N$. Concepts and characteristics of conflict of interest during civil service in Ukraine

\section{CRIMINAL LAW, CRIMINOLOGY, CRIMINAL} AND EXECUTIVE LAW

Afanasenko A., Kondratov D., Bodnar I. Blocking channels of incoming prohibited items to convicts, as a counteraction of penitentionary crime .75

Samofalov L., Samofalov O. Problems of legal regulation of combatinig terrorism and prevention of terrorist acts.

THEORY AND PRACTICE OF CRIMINAL PROCEDURAL ACTIVITY AND CRIMINALISTS. LAW ENFORCEMENT INTELLIGENCE-GATHERING ACTIVITIES

Leonenko O., Yesypenko O., Rakhilchuk I. Modern legal and organizational principles for the development of judicial examination in crime investigation .93

\section{Congratulations}




\section{ЗАГАЛЬНІ ПРОБЛЕМИ ТЕОРІЇ ТА ІСТОРІї ДЕРЖАВИ І ПРАВА, ФІЛОСОФІЯ ПРАВА. КОНСТИТУЦЙНЕ ТА МІЖНАРОДНЕ ПРАВО}

УДК 340.12

DOI 10.32755/sjlaw.2020.02.007

Коба О. В., кандидат педагогічних наук, заступник начальника кафедри службово-бойового застосування підрозділів Національної гвардії України, Київський факультет Національної академії Національної гвардії України, м. Київ, Україна ORCID: 0000-0002-4311-6957;

Коба М. М.,

ад'юнкт, старший викладач кафедри правового забезпечення службово-бойової діяльності, Київський факультет Національної академії Національної гвардії України, м. Київ, Україна

ORCID: 0000-0001-9407-2838

\section{ФОРМУВАННЯ ПРАВОВОЇ КУЛЬТУРИ КУРСАНТІВ НАЦОНАЛЬНОЇ ГВАРДІЇ УКРАЇНИ У ПРОЦЕСІ ПРОФЕСІЙНОЇ ПІДГОТОВКИ}

Стаття присвячена аналізу історії та сучасного стану дослідження теоретико-правовою наукою правової культури, обгрунтуванню необхідності застосування культурологічних принщипів у прочесі правового виховання та професійної підготовки курсантів Національної гвардї України. Виокремлено складові правової культури курсантів Національної гвардії України та рівні, яких досягає курсант у міру оволодіння юридичними знаннями, вміннями та навичками, а також професійно важливими якостями. Визначено найбільш перспективні напрями майбутніх досліджень.

Ключові слова: правова культура, курсанти Начіональної гвардії України, освіта, професійне навчання.

Постановка проблеми. Перетворення, що відбуваються в українському суспільстві протягом останнього часу в усіх сферах суспільного життя - соціальній, економічній, правовій спрямовані на зміцнення та розбудову демократичної, соціальної та правової держави. Водночас відбуваються зміни стосовно 
реалізації прав і свобод людини, створюються необхідні умови для творчого розвитку особи, забезпечення їі гідності і добробуту [1].

Конституція України проголошує пріоритетність правових основ життя, що визначені в ії положеннях, нормах, принципах та підкріплюються демократичними засадами і суспільною практикою. На нинішньому етапі державного будівництва великого значення набуває проблема правового виховання населення, адже в більшості громадян рівень правової свідомості та правової культури має бути значно вищим [2].

Поряд 3 цим накопичений історичний досвід свідчить, що слабка увага до зазначених проблем може негативно відбитися навіть на становищі правового поля та законодавчій базі. Адже без глибокого розуміння соціальної ролі права, суті та змісту правових норм, значення правових відносин неможливе свідоме сприйняття і виконання населенням, державними службовцями вимог правових приписів.

Підвищення морально-гуманістичного потенціалу права, його значення як нормативного вираження соціальної справедливості, міри свободи особистості має сприяти посиленню правового впливу на поведінку шляхом формування уявлень про правомірну і протиправну поведінку, закріплення умов і критеріїв, що характеризують такі уявлення [1].

Аналіз останніх досліджень і публікацій. Проблема сутності правової культури неодноразово перебувала в центрі уваги фахівців у галузі права та інших суспільних наук. Зокрема, іiі досліджували такі вчені, як В. Д. Бабкін, В. В. Головченко, О. В. Дамаскін, В. К. Забігайло, В. Р. Зюбін, М. І. Козюбра, М. Рабінович, В. Т. Томін, О. В. Шмоткін та ін. Усі дослідники 3'ясовували завдання, мету, зміст, принципи, функції, засоби, форми, методи, ефективність правової культури та критерії іiі виміру. Проте, незважаючи на різносторонні дослідження правової культури, остаточного вирішення зазначена проблема поки що не знайшла. Тому спробуємо викласти свої міркування щодо цього.

Кардинальні зміни в дослідженнях проблем правової культури відбуваються на початку 90-х років, коли Україна прого- 
лосила себе незалежною державою. У сучасний період проблеми правової культури населення знайшли висвітлення в працях В. В. Головченка, Г. І. Неліп, М. І. Неліпа, К. М. Левківського, Є. I. Федика та ін., у підручниках 3 теорії держави і права В. О. Котюка, М. М. Марченка, О. Ф. Скакун та ін. Дослідженню різних аспектів правової культури присвячені також праці педагогів М. Д. Касьяненка, Л. С. Нечипоренка, Я. В. Подоляк, В. Г. Паснюк та ін. 3 філософського погляду правову культуру розглядали В. С. Каптарь, В. А. Чефранов, М. Й. Штангерт та ін. Окремі науковці С. I. Камишанченко, В. І. Лозова, I. Ф. Прокопенко розглядають правову культуру як складник економічного, I. Ф. Харламов - морального виховання.

Автори підкреслюють, що нині існують значні резерви для правової підготовки особистості, набуття нею нових правових знань, правових переконань, навичок, умінь, а відповідно підвищення рівня іiї правової свідомості і правової культури, законослухняності, правомірної поведінки та соціально-правової активності. Звертається увага на необхідність дослідження процесу правової культури окремих категорій населення, а саме курсантів Національної гвардії України.

Саме тому вивчення процесів становлення правомірної поведінки майбутніх офіцерів Національної гвардії України, іiі сутності, мотивів зв'язку з правовим регулюванням суспільних відносин, закономірностями соціалізації особистості, іiі практичної діяльності є суттєвою особливістю розвитку юридичної науки в сучасних умовах. Вона повинна все більше ставати наукою про соціальну поведінку людини в правовій сфері суспільства.

Проблема вдосконалення наявного нині рівня правової культури суспільства та його окремих категорій є досить актуальною, що потребує наукового опрацювання його загальнотеоретичних засад.

Метою статті $\epsilon$ уточнення сутності поняття правової культури, аналіз особливостей формування правової культури курсантів Національної гвардії України у процесі їх професійної підготовки.

Виклад основного матеріалу. Правова культура передбачає, з одного боку, необхідність володіння обов'язковим обся- 
гом правової інформації, а з іншого - відповідальне ставлення до неї та готовність і вміння здійснювати правове виховання в процесі професійного та особистого спілкування всіх військовослужбовців Національної гвардії України. Механізм правового регулювання складається із системи засобів, кожен з яких має своє призначення для регулювання суспільних відносин [3, с. 24-25].

Освітній процес у закладах вищої освіти проєктується 3 урахуванням культурних функцій освіти. Культурологічний зміст освіти є джерелом становлення особистості майбутнього фахівця, а озброєння правовими знаннями і вироблення відповідної правової поведінки $є$, таким чином, невідкладним завданням усієї системи освіти і виховання. Із залученням індивіда до системи правового навчання і виховання, що покликана озброїти його необхідними правовими знаннями й соціальними нормами, усвідомленні операції дій перетворюються на внутрішні засоби засвоєння значень. Відкриваються широкі можливості для оволодіння узагальненими значеннями (всезагальними ідеями), тобто поняттями. Таким чином, над чуттєвим рівнем свідомості надбудовується всезагальний рівень [4].

Поняття «правова культура» увійшло в науку на початку XX століття. Узагальнюючий аналіз визначень, представлених О. В. Аграновською, В. І. Камінською, М. К. Подберезьким, О. Ф. Скакун, І. Ф. Фарбером та іншими, дозволяє визначити правову культуру, як глибоке знання джерел права, правильне розуміння завдань правового регулювання, позитивне ставлення до права та його застосування в повсякденному житті. На зв'язок між правовою культурою особи та його ставленням до виконання своїх професійних і громадянських обов'язків звертали увагу Х. С. Гуцеріев, I. М. Кейзеров, А. Ф. Нікітін, А. П. Семітко та ін.

Поділяємо думку М. К. Подберезького, який найбільш чітко розкриває поняття правової культури фахівця та представляє його, як порівняно стійке структурне поєднання інтелектуально-вольових і морально-психологічних, інтегрованих між собою, складових, які, злагоджено і гармонійно взаємодіючи, ви- 
являються як у концептуальній, професійній діяльності, так і в особистому житті [5].

Під правовою культурою курсанта Національної гвардії України розуміємо інтегративну особистісну якість, що характеризується ціннісним ставленням до права, усвідомленим застосуванням правових знань у професійній діяльності, що грунтується на інтелектуальних, моральних, рефлексивних та комунікативних якостях особистості.

Слід зазначити, що основу формування правової культури курсантів Національної гвардії України становлять дисципліни, що вивчаються в процесі навчання в закладах вищої освіти, такі як: теорія держави та права, історія держави та права, конституційне право України та зарубіжних країн, юридична деонтологія, права людини та громадянина, соціогуманітарні основи військово-професійної діяльності, комунікативний аспект діяльності військового командира, правова робота у військових формуваннях тощо. Також важливу роль у процесі формування правової культури майбутніх офіцерів відіграє світоглядне виховання, яке здійснюють військові командири шляхом досконалих, орієнтованих на загальнолюдські цінності, знань, умінь та навичок у межах їх світоглядної компетентності.

В основі правового виховання курсантів Національної гвардії України бачимо культурологічні принципи, тобто такі, які завжди передбачають вияв зусиль розумового, емоційночуттєвого характеру. Логіка аналізу процесу формування правової культури особистості курсанта Національної гвардії України потребує розгляду його через професійну діяльність. На наш погляд, правова підготовка в закладах вищої освіти є не окремою частиною цілеспрямованого, спеціального, організованого впливу на курсантів, а інтегрованою складовою частиною всього навчально-виховного процесу, який за своєю суттю має глибоке культурологічне походження.

Взявши за основу праці В. О. Безбородого, М. К Подберезького, О. Ф. Скакун, можна виокремити такі складові правової культури особистості курсантів Національної гвардії України:

- правосвідомість і правове мислення;

- правомірна поведінка; 
- результати правомірної поведінки і правового мислення [5].

У процесі правової підготовки курсантів Національної гвардії України, спираючись на праці С. І. Федик, доцільно виділити рівні, яких досягає курсант в міру оволодіння юридичними знаннями, вміннями та навичками, а також професійно важливими якостями:

1. Правове знання - представляється, як запам'ятовування i відтворення інформації, що містить термінологію, факти, класифікації, методологію, теорії, закони і принципи.

2. Розуміння - розглядається, як правові знання курсантів, які дозволяють їм вступати в професійні контакти і користуватися наявною інформацією.

3. Застосування - визначає вміння курсантів самостійно застосовувати правила, методи, закони і принципи правових норм.

4. Аналіз - представляється, як уміння розбивати правову інформацію на фоні основної діяльності на частини і розуміти взаємозв'язок між ними.

5. Синтез - позначає вміння майбутнього офіцера об'єднувати правову інформацію, комбінувати її елементи, щоб отримати та ухвалити правильне рішення.

6. Оцінка - дозволяє майбутньому офіцеру і виробляти судження про конкретні результати прийнятих ним рішень та здійснених дій [6, с. 266-269].

Правова культура курсантів Національної гвардії України (загальна та спеціально-професійна) сприяє виробленню культурного стилю правомірної поведінки, який формується залежно від [1]:

- ступеня засвоєння і вияву цінностей правової культури;

- специфіки професійної діяльності майбутніх офіцерів Національної гвардії України;

- індивідуальної неповторності творчості кожної особистості.

Визначивши й уточнивши загальні поняття правової культури особистості, як соціального феномена та складовою моделі особистості, вважаємо, що правова культура майбутніх офіцерів Національної гвардії України може бути представлена, як компонент тезауруса професійного інтелекту фахівця, що міс- 
тить юридичні знання вміння та навички, а також професійно важливі якості, дозволяють ухвалювати і реалізовувати рішення в очікуваних умовах та екстремальних ситуаціях.

На основі узагальнення наукових досліджень виділимо основні компоненти правової культури курсантів Національної гвардії України: когнітивний, діяльнісний та особистіснорефлексивний [7, с. 13-20].

У когнітивному компоненті представлені знання щодо аспектів права, які відображені в правосвідомості майбутніх офіцерів Національної гвардії України, а також професійне правове мислення, що містить системність, швидкість, логічність, аналітичність.

Діяльнісний компонент представлений навичками і вміннями ухвалення правових рішень на тлі основної діяльності в умовах інформаційного та психологічного перевантаження, дефіциту часу. Вказаний компонент також містить навички та вміння організації правової діяльності майбутніх офіцерів Національної гвардії України, їх етики та культури спілкування, проведення ділових переговорів.

Особистісно-рефлексивний компонент дозволяє розвинути в майбутніх офіцерів професійно важливі якості: особистісні, емоційно-вольові, психофізіологічні. Особливу увагу приділено формуванню мотивації, емоційної стійкості та самоконтролю (рефлексіi).

Рефлексія розглядається нами як основне професійне вміння в структурі правової культури курсантів Національної гвардії України під час здійснення правозастосовної діяльності. Вона регулює включення механізмів самооцінки, самоаналізу, самоврядування правозастосовним процесом, які допомагають майбутнім офіцерам адекватно осмислити й оцінити цей процес.

Грунтуючись на дослідженнях у сфері культурологічного підходу [3], доцільно виділити такі функції правової культури курсантів Національної гвардії України, як:

Пізнавальна функція - спрямована на поглиблення правових знань, навичок і вмінь майбутнього офіцера, розвиток його правосвідомості та правового мислення. 
Адаптивна функиія - виражається в соціально-правовій активності особистості майбутнього офіцера та його пристосуванні до умов середовища (правова соціалізація особистості).

Регулятивна функиія правової культури дозволяє майбутнім офіцерам Національної гвардії України співвідносити громадські та особисті інтереси, реалізуючи їх у рамках правового закону.

Комунікативна функиія забезпечує спілкування курсантів Національної гвардії України в середовищі цього виду військового формування.

Висновки. У нашому розумінні формування правової культури курсантів Національної гвардії України має бути побудовано так, щоб здобуті в процесі здобуття вищої освіти правові знання, вміння та навички, а також професійно важливі якості ставали об'єктом ціннісної орієнтації особистості майбутніх офіцерів цього військового формування. Найбільш перспективними напрямами майбутніх досліджень цієї проблематики $\epsilon$ розроблення комплексу заходів щодо підвищення рівня правової культури майбутніх офіцерів Національної гвардії України, а також зміцнення їх морально-етичних принципів як явища, яке має бути віднесеним до категорії найважливіших напрямів діяльності вищої школи.

\section{Список використаних джерел}

1. Легуша С. М. Сутність, функції і механізм правового виховання курсантів вищих навчальних закладів МВС України: автореф. дис. ... канд. юрид. наук. Київ, 2002. 17 с.

2. Конституція України: станом на 1 верес. 2016 р.: відповідає офіц. тексту. Харків: Право, 2016. 82 с.

3. Голосніченко І. П. Правосвідомість і правова культура у розбудові Української держави. Право України. 2005. №4. С. 24-25.

4. Костенко О. М. Що є право? Про основи «натуралістичної» юриспруденції у світлі соціального натуралізму. Соціальна мережа науковців. URL: https://www.science-community.org/ru/node/1390.

5. Подберезський М. К. Правова культура майбутнього вчителя. Харків: Основа, 1997. 220 с.

6. Федик Є. І. Правова культура та ії різновиди (загальнотеоретична характеристика). Право та культура: теорія і практика: матеріали міжнар. наук.-практ. конф. / за ред. Ю. Шемчушенка, В. Кампо, 
М. Поплавського (м. Київ, 15-16 травня 1997 р.). Київ: Леся, 1997. C. $266-269$.

7. Омельчук I. А. Особливості оціночного компонента правосвідомості молоді. Вісник Хмельницького інституту регіонального управління та права. Хмельницький, 2003. № 2 (6). С. 13-20.

Koba O., Koba M.

\section{FORMATION OF LEGAL CULTURE OF CADETS OF THE NATIONAL GUARD OF UKRAINE IN PROFESSIONAL TRAINING PROCESS}

The article reveals the main provisions of the legal culture of cadets of the National Guard of Ukraine in the process of professional training, in the context of defining its essence, functions and mechanism. The content of legal culture is analyzed considering the fact that the changes take place in the system of vocational education, public relations, and personal consciousness.

The concept of the legal culture of cadets of the National Guard of Ukraine, we understand as the integrative personal quality, characterized by a valued attitude to law, conscious application of legal knowledge in professional activities based on intellectual, moral, reflective and communicative qualities of an individual.

Peculiarities of professional activity of military personnel of the National Guard of Ukraine strengthen the requirements to the legal culture of future officers, who must be able to determine their worldview priorities and to be responsible for their behavior.

The formation of the legal culture of future officers directly depends on the level and quality of their professional training in higher educational institution. An important role in the formation of the legal culture of future officers of the National Guard of Ukraine is played by worldview education, carried out by military commanders through perfect, focused on universal values, knowledge, skills and abilities within their worldview competence.

The professional training of cadets of the National Guard of Ukraine in a higher educational institution should be based on the norms of morality, ethics, religion, corporate norms and traditions, which also form the legal basis of their professional activity.

The presence of a high level of legal culture of the future officers of the National Guard of Ukraine after graduating from higher educational institution is a mandatory condition for the quality performance of their professional responsibilities.

Considering the current needs for training military personnel in the structure of the National Guard of Ukraine as high-level professionals, with the appropriate level of legal awareness and legal professional culture, it is necessary to clarify the concept, essence, content, functions and forms of legal education of cadets of the National Guard of Ukraine as the basics of their future professional activity.

Key words: legal culture, cadets of the National Guard of Ukraine, education, vocational training. 


\section{References}

1. Lehusha, S. M. (2002), The essence, functions and mechanism of legal education of cadets of higher educational institutions of the Ministry of Internal Affairs of Ukraine: avtoref. dys. ... kand. yur. nauk, Kyiv.

2. Constitution of Ukraine: dated September 1, 2016: correspond to the official website (2016), Pravo, Kharkiv.

3. Holosnichenko, I. P. (2005), "Legal awareness and legal culture in the development of the Ukrainian state", Law of Ukraine, № 4, pp. 24-25.

4. Kostenko, O. M. (2010), "What is Law? On the foundations of "naturalistic" jurisprudence in the light of social naturalism", available at: www.science-community.org/ru/node/1390 (accessed 22 June 2020).

5. Podberezkyi, M. K. (1997), Legal culture of the future teacher, Osnova, Kharkiv.

6. Fedik, E. I. (1997), "Legal culture and its varieties (general theoretical characteristics)", Law and culture: theory and practice: materials of International scientific and practical conference, in Shemchushenko, Yu., Kampo, V., Poplavskyi, M. (Ed.), Kyiv, pp. 266269.

7. Omelchuk, I. A. (2003), "Features of the evaluative component of youth legal awareness", Bulletin of the Khmelnytsky University of Management and Law, № 2 (6), pp. 13-20. 
УДК 35.08

DOI 10.32755/sjlaw.2020.02.017

Любич С. В., аспірант 2 курсу Академії Державної пенітенціарної служби, м. Чернігів, Україна ORCID: 0000-0002-4636-1042

\section{МОДЕЛІ ДЕРЖАВНОЇ СЛУЖБИ В ЄВРОПЕЙСЬКІЙ СПІЛЬНОТІ}

У статті систематизовано досвід використання моделей організаиіі публічної служби в європейській спільноті. На основі викладеного матеріалу проводиться аналіз найбільш поширених моделей публічної служби в Європі. Окреслено основні характеристики та значення для представлених країн, на основі досвіду деяких європейських країн розкрито загальні тендениії розвитку представлених моделей публічної служби.

Досліджено можливість використання досвіду організаиії моделей державної служби в краӥнах з пошуком оптимальної моделі організаиї управління в тому числі України.

Ключові слова: моделі державної служби; публічна служба; європейська спільнота; модель нової публічної служби.

Постановка проблеми. Результати системних перетворень моделей публічної служби, що їх зазнали за останні роки країни європейської спільноти, свідчать, що модернізовані системи публічної служби в умовах глобалізації не завжди набувають рис, притаманних моделі, взятій за взірець, а інколи приводять до появи нових, модифікованих, гібридних форм їх змішаній організації [1, с. 107].

Незважаючи на постійні спроби модернізації державної служби, пошук оптимальної моделі, європейською спільнотою вироблений історично-конструктивний пласт ефективного вирішення організації публічної служби. Основні характеристики організації публічної служби знаходять своє відображення у відповідній моделі, дефініція моделі організації держслужби систематизована множина умов і характеристик публічної служби, що розкриває іiі організаційно-функціональні особливості. На сьогодні в європейській спільноті реалізується ціла низка різних моделей публічної служби, що у свою чергу, дає можливість їх систематизувати та дослідити. Узагальнення та аналіз моделей сприятиме пошуку для України такої моделі, яка від- 
повідатиме потенціалу держави, цілям іï розвитку, кращим європейським практикам [2, с. 141].

Аналіз останніх досліджень і публікацій. На сьогодні вченими та дослідниками вивчено й систематизовано такі особливості, як сутність, основні принципи, характерні та відмінні риси моделей публічної служби - Л. Прокопенко, О. Оболенський, Н. Липовська, Ю. Ковбасюк, С. Дубенко, Х. Дейнега, М. Багмет та інші; серед зарубіжних дослідників - Д. Боссарт, Ж. Зіллер, А. Клесс, Ж. Пено.

Проте, незважаючи на велику кількість напрацювань 3 цієї проблематики, варто зауважити, що на часі залишається аналіз та систематизація як класичних моделей публічної служби, так i «змішаних», постмодерністських, адже саме визначення моделі держслужби та ії характеристик лежить в основі творення нової публічної служби України як невід’ємної складової європейської спільноти.

Мета статті - описати, систематизувати та узагальнити моделі публічної служби, розкрити характерні ознаки класичних, змішаних та нових моделей державної служби, які представлені в країнах європейської спільноти.

Виклад основного матеріалу. В усіх сучасних державах європейської спільноти застосовується одна 3 трьох класичних моделей публічної служби - кар'єрна, посадова та змішана, остання поєднує в собі елементи кар'єрної та посадової моделей. Більшість країн Європейського Союзу і власне Європейський Союз побудували свою публічну службу за принципом кар'єрної моделі. Це передусім Франція, Німеччина, Данія та Іспанія.

Посадова модель діє в Швеції, Нідерландах, змішана модель отримала поширення в Італії. Серед нових членів СС існують як прибічники кар'єрної моделі (Болгарія, Кіпр, Румунія, Словаччина, Словенія), так і змішаної (Латвія, Литва, Польща, Мальта, Угорщина, Чехія), в Естонії запроваджена посадова модель.

Зауважимо, на практиці жодна 3 країн європейської спільноти сьогодні на має тієї чи іншої моделі публічної служби в чистому вигляді. У кожній 3 домінуючих моделей присутні елементи іншої. Так, у Франції існують категорії посад держ- 
службовців центральних органів влади та органів місцевого самоврядування, які наймаються за принципами посадової публічної служби - за контрактом, або за угодою (члени кабінету міністрів, директор кабінету міністрів, генеральний директор у мерії та ін.). У Нідерландах та Швеції окремі категорії службовців, як працівники дипломатичного корпусу та поліція, наймаються $з$ принципами кадрової служби. Але існування певної категорії посад, які не відповідають загальноприйнятим нормам, не $є$ підставою для класифікації тієї чи іншої публічної служби, як змішаної, оскільки існування цих посад є законодавчо оформленим винятком 3 правил, а не нормою [3, с. 77].

Кар'єрна модель базується на принципі специфічності публічної адміністрації, що зумовлює наявність персоналу, наділеного особливими можливостями, який присвячує все своє професійне життя службі в державному органі. Службовець, який отримав підготовку, необхідну для найму на роботу, та пройшов конкурс, або успішно склав державний іспит, піднімаючись ієрархічною структурою посад відповідно до наявного механізму просування по службі, реалізує свій кар'єрний потенціал. Кар'єрна модель передбачає встановлення ієрархічного порядку для посад таким чином, щоб державний службовець, прийнятий на певний посадовий рівень, міг за визначений термін перебування на тій чи іншій посаді пройти послідовну низку рівнів, аж до найвищого. Внаслідок того, що набір залежить від різних рівнів освіти, в кожній системі посад існують горизонтальні поділи, які відповідають цим рівням, та вертикальні, які враховують різноманітність професій у державній адміністрації.

Таким чином, найбільш характерними рисами кар'єрної моделі публічної служби є такі: наявність спеціальних статутних вимог щодо освіти, необхідної для найму та кар'єри; обмеження визнання професійного досвіду роботи в приватному сектоpi; призначення службовця тільки на найнижчі посади визначеного кар'єрного рівня та просування по службі за вислугою років; наявність законодавчо визначеної системи оплати праці та спеціальної пенсійної системи; робота впродовж життя; чітко визначений принцип субординації; статутно, або нормативно 
закріплений кодекс поведінки публічних службовців, їх прав та обов'язків [3, с. 79].

Посадова модель публічної служби повністю організовується виходячи з короткострокових потреб у персоналі. Набір проводиться на конкретну посаду, а не до номенклатурної групи, професії чи будь-якої іншої групи, яка дає можливість бути призначеним на певну кількість посад. Робота на державний орган прирівнюється до праці за будь-якою іншою професією. Службовець не повинен реалізовувати свій професійний потенціал лише в рамках публічної служби, він може вільно переміщатися між приватним і державним секторами. Але це не означає, що він не має можливості зробити кар'єру в системі посадової служби. Приклад Нідерландів показує, що кар'єра і служба за наймом не виключають одна одної. Там службовець може зробити кар'єру, заміщуючи різні послідовні посади. Головну відмінність між двома системами можна стисло висловити у формулі, за якою в «найманій системі просування державного службовця є проблемою індивіда, тоді як у кадровій системі воно є справою адміністрації» [3, с. 83].

Таким чином, характерними елементами посадової моделі публічної служби є трудові відносини на основі контракту, призначення на всі можливі посади без попередньої цільової підготовки, визнання професійного досвіду, набутому в приватному секторі, відсутність законодавчо встановленої системи кар'єрного зростання та спеціальної пенсійної системи. Зважаючи на ці характеристики, здавалося б, що за посадової моделі публічної служби існування спеціального статуту для публічних службовців $є$ неможливим. Однак, як свідчить досвід Нідерландів, наявність статуту публічних службовців не відносить автоматично інститут публічної служби певної країни до кадрової моделі [3, с. 84].

Публічна служба більшості країн складалася протягом тривалого історичного розвитку, при цьому кожне суспільство, зважаючи на соціальні характеристики, національну філософію, менталітет та ідеологію, вірування і традиції, виробляє власне розуміння функцій держави. Водночас, незважаючи на різноманіття держав, простежуються деякі подібні риси систем публічної служби, що дає можливість обгрунтовувати їхні теоретичні 
моделі. Можемо вважати, що державна служба кожної окремої країни лише тяжіє до якоїсь однієї моделі i, як правило, поєднує в собі окремі елементи інших моделей державної служби. Сучасні тенденції реформування публічної служби свідчать про зближення, взаємозбагачення та взаємопроникнення різних моделей державної служби.

На становлення моделі публічної служби впливає низка факторів, як-то:

- особливості історичного розвитку держави;

- специфіка правової системи (англосаксонська, для якої характерна відсутність уніфікованої системи законодавства 3 питань державної служби та наявність великої кількості розрізнених нормативних правових актів, або романо-германська правова система, в якій основними регуляторами державної служби є конституція і комплексні закони);

- форма держави (форма державного устрою, форма державного правління, політичний режим).

Один із підходів виділяє декілька регіональних моделей публічної служби: континентальну та англосаксонську. Континентальна модель державної служби базується на кар'єрному зростанні, основним принципом якої $\epsilon$ «присвячення себе службі держави». Публічні службовці вступають на службу на весь період своєї професійної кар'єри, під час якої вони поступово просуваються по службі. Така система тривалого або (чи) довічного найму службовців притаманна країнам Західної та Центральної Європи.

Англосаксонська модель відповідає посадовій системі державної служби зі строковим контрактним наймом службовців, які наймаються відповідно до освітнього і професійного рівня. У них відсутні гарантії кар'єрного зростання, притаманні континентальній моделі. До такої моделі тяжіють, зокрема Велика Британія. Слід вказати, що сучасні тенденції в еволюції державного управління породжують системи, в яких поєднуються елементи обох моделей. Більшість дослідників стверджують, що це повною мірою стосується і системи державної служби в Україні [4, с. 42].

Прихильники ще одного підходу, аналізуючи організаційноправову структуру державної служби та іï адміністративно-пра- 
вову регламентацію, пропонують таку типологію: романо-германська модель (кар'єрна) - характеризується тенденцією до кодифікації норм, прагненням до простоти і точності. Державну службу романо-германських країн можна віднести до (кар'єрного типу), що характеризується детальною розробкою нормативно-правових актів, докладною регламентацією повсякденної діяльності чиновників, функціонуванням державної служби за принципом ієрархічності, вірнопідданості державі. Ця модель реалізується в таких країнах, як Франція та Німеччина. Основна iii риса - орієнтація на «закритість» кар'єри і нематеріальні пільги і гарантії на державній службі (соціальний захист державних службовців, стабільність статусу). Вступ на державну службу відбувається на основі конкурсного іспиту за принципом рівності всіх кандидатів. Певним недоліком такої моделі $є$ відсутність можливості міжвідомчої мобільності чиновників, що стало однією з найбільш гострих проблем кар'єрних моделей.

Для корпоративної моделі вступ на державну службу є результатом жорсткого конкурсного відбору за принципом «правильна людина на вакансію». Особливістю цієї моделі є контрактна система трудових відносин 3 державними службовцями. При вступі на службу практично немає таких понять, як «ліміт штатної чисельності» і «реєстр посад». Перший керівник державного органу сам має право вирішувати, скільки потрібно працівників для досягнення поставленої мети.

Характерними особливостями «корпоративної моделі» можна вважати:

- повну орієнтацію на ринок праці;

- відмова від чіткого визначення штатної чисельності держслужбовців;

- впровадження принципів корпоративного управління [4, c. 44].

Виділяють зв'язок організації публічної служби 3 державним устроєм, який дозволяє виділити державну службу у федеративних та унітарних державах. На підставі класифікації двох видів державної служби можна виділити кілька основних моделей державної служби, що існують у сучасних зарубіжних країнах: централізована і децентралізована. 
Централізована модель державної служби відзначається жорсткою організаційною структурою управління та урядовим органом із широкими повноваженнями, що передбачає наявність єдиної системи та форми оплати праці для всіх державних органів, а також координацію організації праці і кадрового забезпечення.

Децентралізована модель державної служби характерна розосередженістю організаційної структури державної служби, повною відсутністю чи суттєвим звуженням повноважень спеціального уповноваженого органу, делегуванням широких кадрових повноважень усім міністерствам, відомствам та іншим державним органам.

Вітчизняні науковці зазначають відносні переваги і недоліки кожної моделі. Зокрема, для централізованої моделі перевагою $є$ системність і послідовність в ухваленні державних рішень; недоліками - консерватизм, відірваність широких повноважень центрального органу від відповідальності за фактично виконану роботу на місцях. Перевагами децентралізованої моделі $є$ гнучкість, динамічність у прийнятті рішень, чіткий зв'язок між повноваженнями керівників державних органів у частині кадрового забезпечення та відповідальністю за результатами роботи державних службовців; недоліками - відсутність системності в організації і розвитку державної служби, високий рівень конфліктності [5, с. 18-19].

Західні дослідники комбінують критерії типологізації моделей державної служби і називають: централізовану закриту модель, реалізовану в унітарній державі (Франція); децентралізовану закриту модель, реалізовану в федеративній державі (Німеччина).

Традиційна модель державної служби, для якої характерна «служба, орієнтована на владу». Характеризується безправ'ям службовця перед політичною владою; відсутністю якої б то не було корпоративності, внутрішньої автономії, гарантій кар'єри; чиновник виступає як особистий виконавець правителів і держави. Цю модель характеризує повне злиття державної служби з політикою. 
Модернізаційна модель державної служби, в основі якої лежить «служба, орієнтована на суспільство». Характеризується правовою та соціальною захищеністю державних службовців, їх автономною від політичної влади організацією, розвиненістю корпоративного духу; незалежність від політики поєднується 3 підпорядкованістю уряду демократичним контролем.

Транзиторна модель публічної служби, відмітною ознакою якої є «служба, орієнтована на саму себе». Характеризується політико-правовою безконтрольністю чиновника, який вийшов 3-під нагляду авторитарної держави, але ще не контролюється сильним громадянським суспільством і демократичною державою; вищі посадові особи діють у своїх особистих інтересах в управлінні домінують формалізм і чиновницький ритуал [6, с. 15].

Модель нової публічної служби (New Public Service) - бере початок 3 1980-х рр., як наслідок теоретичного осмислення практичного використання концепції «Нового державного менеджменту» (New public management), яка зокрема, була впроваджена у Великій Британії. Публічна служба в межах цієї моделі призначена для надання послуг суспільству на принципах, що застосовуються в приватному секторі, а іiі функціональною особливістю стає те, що вона більшою мірою координує діяльність надавачів послуг, а не регулює іiі. У центрі уваги публічних службовців перебувають потреби та інтереси суспільства. На сьогодні модель нової публічної служби в різних модифікаціях та різною мірою представлена практично в усіх країнах європейської спільноти.

Окремі елементи запроваджені в Україні: дозвільні офіси, адміністративні центри, громадські ради, громадські експертизи, громадські слухання, профілі професійної компетентності посадовців та ін.

Постмодерністська модель публічної служби, або як іï скорочено називають Post - NPS (NPS - New Public Service), формується в 90-х pp. XX ст., коли фокус уваги переводиться з головних елементів раціонально-бюрократичної системи на публічних службовців, як людей, їх індивідуальні свободи та гуманістичні чинники, що суттєво визначає ефективність публічного управління. Основні категорії, які розкривають сутність 
цієї моделі: суспільні та особистісні цінності, гуманізм, організаційні цінності розвитку, організаційний клімат, відкритість організаційних систем, мережі. Прихильники цієї моделі вважають, що в сучасному глобалізованому середовищі публічне управління має грунтуватися на щирому і відкритому діалозі між усіма сторонами, в тому числі громадян 3 публічними службовцями [2, с. 144-145].

Змішана модель публічної служби характеризується існуванням усередині кадрової системи певного переліку посад зі своїм специфічним режимом організації кар'єри та доступу до публічної служби. Наприклад, у Великій Британії існує порядок призначення на деякі посади без організації конкурсу. Цей випадок законодавчо закріплено в постановах уряду про державну адміністрацію, які передбачають, що від необхідності отримувати класифікаційні сертифікати звільняються посади, на які призначення проводяться безпосередньо вищою владою Британії. Здебільшого це посади вищих держслужбовців центральних органів влади. 3 відставкою члена уряду ці чиновники також ідуть у відставку.

Змішаний характер системи виявляється також у контрактних відносинах між службовцем і державним, або муніципальним органом, який його наймає. У цьому випадку службовці не мають статусу державного службовця, але в більшості випадків, потрапляють під юрисдикцію публічного права [3, с. 84].

Висновки. Отже, систематизацію та узагальнення основних моделей державної служби в цьому дослідженні можна вважати умовною, але деякою мірою практично значущою для країн 3 пошуком оптимальної моделі організації публічної служби. Окреслений підхід до вивчення проблеми пошуку оптимальної моделі державної служби підсилює роль «нових моделей організації публічної служби», тим самим відкриває здатність їх інтегруватися в окреслені моделі теорії публічної служби як самостійного інституту.

Врахування європейського досвіду стає головним питанням під час вибору оптимальної моделі організації державної служби. Серед наявних класифікацій досліджено «класичні», іншими словами, традиційні моделі (кар'єрна, посадова), змішані моделі (інтегрують у собі елементи різних моделей); моделі з урахуван- 
ням регіональних особливостей (континентальна, англосаксонська, романо-германська); моделі публічної служби у зв'язку 3 державним устроєм (централізована та децентралізована); «нові моделі публічної служби» (модернізаційна, транзиторна, модель нової публічної служби, постмодерністська модель).

Таким чином, представлена характеристика моделей державної служби носить теоретичний характер, але тим самим окреслює певні характерні лінії, принципи та функціональні особливості моделей, які використовуються публічною службою в європейській спільноті.

\section{Список використаних джерел}

1. Линдюк О. А. Свропейський досвід модернізації державної служби та перспективи його застосування в Україні. Теоретичні та прикладні питання державотворення. 2016. Вип. 19. С. 104-116.

2. Хорошенюк О. В. Моделі організації публічної служби: порівняльний аналіз та пропозиції для України. Державне управління: теорія та практика. 2014. № 1. С. 140-150.

3. Прокопенко Л. Публічна служба в країнах ЄС. Публічне адміністрування: теорія і практика. Дніпропетровськ: ДРІДУ НАДУ, 2009. Вип. 1. С. 76-86.

4. Мамчур Г. В. Види і моделі державної служби. Вісник Київського національного університету імені Тараса Шевченка. 2014. Вип. 1. С. 41-45.

5. Неліпа Д. В. Організаційно-правові засади державної служби в Україні: навч. посіб. для студ. вищ. навч. закл. Наu. ун-m ім. Tараса Шевченка. Київ: Центр навчальної літератури, 2012. 367 с.

6. Комаровский В. С. Государственная служба и средства массовой информации (курс лекций). Воронеж: Издательство Воронежского Государственного Университета, 2003. 114 с.

\section{Liubych S. PUBLIC SERVICE MODELS IN EUROPEAN COMMUNITY}

The article presents the experience of using models of public service organization in the European community. The analysis of the most widespread models of public service in Europe is carried out on the basis of the presented material. The general tendencies of the presented models development of public service are also revealed. The possibility of using the experience of organizing models of public service in countries with the search for the optimal model of organization of government, including Ukraine is examined. The article presents the key characteristics of the public service organization, which are reflected in the corresponding model - a systematized set of conditions and characteristics of the public service, which reveals its organizational and functional features. The article 
clarifies and summarizes the presented models of public service, outlines the characteristics of classical, mixed and new models of civil service. The classic models of public service - career, job and mixed are described in detail. Special attention is given to «new models of public service» (modernization, transitory, model of new public service, postmodern model). In practice none of the countries of the European Community today has one or another model of public service in its purest form. The article analyses of each separate model of public service, and it is concluded that elements of public service of the listed countries only gravitate to any one model and, as a rule, combine elements of others. Current trends in public service reform indicate the convergence, mutual enrichment and interpenetration of different models of civil service in the European environment. Particular emphasis is put on the influence of a number of factors, such as (the peculiarity of the historical development of the state, the specifics of the legal system, the form of government, political regime), and so on. The author shows that there are a number of closely studied models of public service: the modernization model, which is based on "society-oriented service»; a transient model of public service, the hallmark of which is "self-centred service»; models of the new public service; postmodern model of public service or as it is abbreviated as Post - MPS. It should be noted that there is a widespread influence of a mixed model of public service, which is characterized by the existence within the personnel system of a certain list of positions with its own specific regime of career organization and access to public service.

Key words: public service models; public service; European community; new public service model.

\section{References}

1. Bossart, D. (2004), Civil service in the countries - candidates for accession to the EU: new trends and the impact of the integration process / translated by Shalenko, O., Millennium, Kyiv.

2. Ziller, J. (1996), "Political - administrative systems of the EU", Comparative analysis / translated by Khovkhuna, V., Osnova, Kyiv.

3. Komarovskyi, V. S. (2003), Civil Service and the media (Course of lectures), Izdatelstvo Voronezhskogo Gosudarstvennogo Universiteta, Voronezh.

4. Lindiuk, O. A. (2016), "European experience of civil service modernization and prospects for its application in Ukraine", Theoretical and applied issues of state formation, Issue 19, pp. 104-116.

5. Mamchur, G. V. (2014), "Types and models of public service", Bulletin of Taras Shevchenko National University, Issue. 1, pp. 41-45.

6. Nelipa, D. V. (2012), Organizational - legal principles of civil service in Ukraine: manual, Kiev National Taras Shevchenko University, Centre of Educational Literature, Kyiv. 


\section{ПРОБЛЕМИ ЦИВІЛЬНОГО, ГОСПОДАРСЬКОГО, СОЦАЛЬНОГО ТА ТРУДОВОГО ПРАВА}

УДК 347.1

DOI 10.32755/sjlaw.2020.02.028

Нішимна С. O., доктор юридичних наук, професор, завідувач кафедри адміністративного, цивільного та господарського права і процесу, Академія Державної пенітенціарної служби, м. Чернігів, Україна ORCID: 0000-0001-7424-7688;

Зливко С. В., доктор юридичних наук, професор кафедри адміністративного, цивільного та господарського права і процесу, Академія Державної пенітенціарної служби, м. Чернігів, Україна ORCID: 0000-0003-2732-3144;

Сикал М. М., кандидат юридичних наук, доцент кафедри адміністративного, цивільного та господарського права і процесу, Академія Державної пенітенціарної служби, м. Чернігів, Україна ORCID: 0000-0003-0334-4047

\section{СПОЖИВЧІ ТОВАРИСТВА ЯК ОРГАНІЗАЦІЙНО- ПРАВОВА ФОРМА ЮРИДИЧНОЇ ОСОБИ}

У статті визначено статус споживчого товариства як однієї з організачійно-правових форм юридичних осіб, щзо $\epsilon$ й однією з організаційноправових форм активізачії участі громадян у господарюванні та задоволенні ї власних потреб.

Проаналізовано норми Цивільного та Господарського кодексів України, Законів Украӥни «Про кооперацію» та «Про споживчу кооперацію», відповідно до яких споживчим товариством визнається самостійна, демократична організачія громадян, які на основі добровільності членства і взаємодопомоги за місием прожсиання або роботи об'єднуються для спільного господарювання з метою поліпшення свого економічного і сочіального стану.

Ключові слова: кооператив, споживче товариство, ознаки споживчих товариств.

Постановка проблеми. 3 прийняття 28 червня 1996 року Конституції України в нашій державі на законодавчому рівні відбулося закріплення положення, відповідно до якого суспільне життя в Україні грунтується на засадах економічної багато- 
манітності (стаття 15) [1], що стало правовою основою для діяльності різних організаційно-правових форм юридичних осіб.

За сучасних умов особливо зростає роль споживчих товариств, які покликані забезпечувати економічний та соціальний добробут громадян. Із встановленням у нашій державі демократичного режиму відбувається реформування законодавства, що регулює діяльність юридичних осіб. Тому постає завдання дослідження та вдосконалення поняття та правового статусу споживчих товариств, усунення упередженості щодо них з боку громадян, яка була спричинена соціалістичним режимом.

Аналіз останніх досліджень і публікацій. Вивчення цієї проблеми прослідковується насамперед у працях таких учених, як М. В Аліман, С. Г. Бабенко, Т. Г. Васильців, В. І. Вахитов,

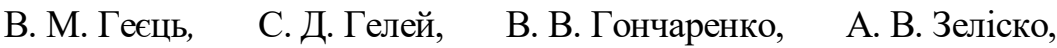
В. В. Зіновчук, А. В. Меркулов, Н. Г. Міценко, Ю. М. Меншикова, Н. В. Мокєрова, О. О. Нестуля, Г. П. Скляр, В. І. Тереховська, Ю. В. Тимченко та інші.

Метою статті $\epsilon$ визначення проблем правового статусу споживчих товариств та їх місця у системі юридичних осіб.

Виклад основного матеріалу. Закон України «Про споживчу кооперацію» у ч. 1 статті 5 встановлює, що первинною ланкою споживчої кооперації є споживче товариство - самостійна, демократична організація громадян, які на основі добровільності членства і взаємодопомоги за місцем проживання або роботи об'єднуються для спільного господарювання 3 метою поліпшення свого економічного і соціального стану [2]. Виходячи 3 викладеної норми Закону можна виділити такі ознаки споживчого товариства:

- це організація (самостійна та демократична);

- добровільними членами такої організації можуть бути громадяни, які об’єднуються за місцем роботи чи проживання;

- об'єднання громадян здійснюється для спільного господарювання $з$ метою поліпшення свого економічного та соціального стану.

Перелічені в понятті ознаки не можуть бути спеціальними ознаками споживчих товариств, які дають підстави для виділення їх як окремого виду юридичної особи. 
По-перше, така ознака, як самостійність організації, характерна для будь-якої юридичної особи, оскільки остання є самостійним суб'єктом правовідносин, а щодо ознаки «демократичності організації», то, навряд чи критерій демократичності та недемократичності можна застосовувати до правової характеристики юридичної особи.

По-друге, відповідно до статті 100 Цивільного кодексу України право участі в товаристві є особистим немайновим правом, а звідси участь у будь-якій юридичні особі - це право фізичної особи, а отже, і членство у товариствах $є$ завжди добровільним [3].

По-третє, вказівка на можливість здійснення господарської діяльності у споживчому товаристві є помилковою, оскільки члени товариства «спільно не господарюють», тому що цю діяльність здійснює безпосередньо юридична особа. Такий висновок можна зробити, враховуючи частину 2 статті 55 Господарського кодексу України, відповідно до якої господарську діяльність здійснюють суб’ єкти господарювання (юридичні особи, їх відокремлені підрозділи, фізичні особи, зареєстровані як підприємці) [4].

По-четверте, поліпшення економічного і соціального стану учасників може бути метою будь-якого підприємницького товариства, яка досягається шляхом отримання прибутку та його розподілу між учасниками [4].

Отже, розглянуті ознаки споживчого товариства, визначені статтею 5 Закону України «Про споживчу кооперацію», не дають змоги виділити ті ознаки, які властиві лише для споживчих товариств.

Закон України «Про кооперацію» відносить споживчі товариства до видів кооперативу та визначає їх у статті 2 як кооператив, який утворюється шляхом об'єднання фізичних та/або юридичних осіб для організації торговельного обслуговування, заготівель сільськогосподарської продукції, сировини, виробництва продукції та надання інших послуг з метою задоволення споживчих потреб його членів [5].

Таке визначення споживчого товариства містить ознаки, відмінні від тих, що передбачені Законом України «Про спожи- 
вчу кооперацію». Закон «Про кооперацію» надає право бути членами споживчих кооперативів (товариств) не тільки фізичним особам, але і юридичним особам; характеризує споживчі (товариства) кооперативи через перелік видів діяльності, які може здійснювати товариство (торговельне обслуговування, заготівля сільськогосподарської продукції, сировини, виробництво продукції та надання послуг іншим особам). Але такими видами діяльності можуть займатися не тільки споживчі товариства, але й інші юридичні особи. Дещо по-іншому у Законі «Про кооперацію» сформульована мета споживчого товариства (кооперативу), якою відповідно до Закону України «Про кооперацію» $є$ задоволення споживчих потреб його членів, хоча вона дещо й збігається $з$ метою споживчого товариства, що визначена у Законі «Про споживчу кооперацію» як поліпшення економічного та соціального стану членів товариства. Відсутність специфічних ознак споживчого товариства (кооперативу) в понятті, яке міститься в Законі України «Про кооперацію», дає підставу для висновку, що цей нормативно-правовий акт лише виділяє такий вид кооперативів, як споживчі товариства, не встановлюючи їх спеціальних ознак, які дають підставу виділяти їх в окрему організаційно-правову форму.

Визначення споживчого товариства закріплене також Господарським кодексом України [4] у статті 111, де споживче товариство це - самоврядна організація громадян, які на основі добровільності членства, майнової участі та взаємодопомоги об’єднуються для спільної господарської діяльності з метою колективного організованого забезпечення своїх економічних $\mathrm{i}$ соціальних інтересів. Кожний член споживчого товариства має свою частку в його майні. Як видно, поняття споживчого товариства визначається через поняття «самоврядна організація».

Що стосується терміна «самоврядна», то він має значення, яке тотожне поняттю «самоуправління». «Самоврядна» означає та, яка самостійно вирішує питання внутрішнього управління [6, с. 128]. Термін самоврядна організація застосовується в багатьох законодавчих актах у різних значеннях. Тому така ознака, як самоврядність споживчих товариств, є родовою, та не може слугувати відмінною ознакою споживчих товариств від 
інших юридичних осіб. Не є спеціальною ознакою й добровільність членства. Викликає критику виділення в дефініції споживчого товариства такої неправової ознаки, як «взаємодопомога» під час здійснення господарської діяльності, оскільки це $\epsilon$ поняття суто соціальне і не може бути покладене в основу визначення правого поняття тієї чи іншої юридичної особи. Інакше формулюється мета споживчого товариства - колективне організоване забезпечення своїх економічних і соціальних інтересів. «Колективне організоване» забезпечення мети діяльності не може закріплюватись як ознака споживчого товариства, адже виконання мети товариства здійснює не колектив, а юридична особа, що $є$ учасником цивільно-правових відносин. Забезпечення ж економічних і соціальних інтересів може бути метою не лише споживчих товариств, а й будь-яких інших підприємницьких товариств, зокрема господарських товариств.

Отже, вищенаведені нормативно-правові акти дають різні ознаки споживчих товариств, і визначити, які ж саме з перелічених ознак $є$ правильними, важко. Можна лише сказати, аналізуючи ці нормативно-правові акти, що передбачені чинним законодавством ознаки споживчих товариств не носять цивільноправовий характер. Така ситуація стала наслідком того, що принципи правового регулювання системи споживчих товариств, сформовані за часів існування СРСР, нині майже не змінилися. Усі визначення споживчих товариств, закріплені в чинних нормативно-правових актах, дано через ті їх ознаки, що були характерними для системи споживчої кооперації в СРСР, i які абсолютно не відповідають сучасним фактичним умовам функціонування споживчих товариств як учасників цивільноправових відносин. Саме тому виникає необхідність розроблення нової правової моделі споживчих товариств, конструкція якої буде враховувати сучасні тенденції розвитку законодавства європейських країн.

У зв’язку з цим можна сформувати перелік цивільно-правових ознак споживчих кооперативних товариств, які відрізнятимуть їх від будь-яких інших товариств, а саме: непідприємницький правовий статус споживчого товариства; сукупність майнових прав членів товариства; об'єкти права власності чле- 
нів товариства; відповідальність членів товариства за зобов'язаннями споживчого товариства. Ці ознаки дають змогу виділити споживчі товариства в окрему організаційно-правову форми непідприємницьких товариств.

Цивільний кодекс України у статті 86 поділяє юридичні особи залежно від порядку їх створення на юридичні особи приватного права та публічного права. Юридичні особи приватного права створюються за ініціативою приватних осіб (як фізичних, так і юридичних) та поділяються статтею 83 Цивільного кодексу України на підприємницькі та непідприємницькі товариства. Саме до останніх цей кодифікований акт відносить споживчі товариства (стаття 86 Цивільного кодексу України). Як вид непідприємницького товариства споживче товариство відповідно до положень Цивільного кодексу України не має на меті одержання прибутку для його наступного розподілу між учасниками.

Нормативно-правові акти, які покликані врегульовувати особливості правового статусу споживчих товариств як виду непідприємницьких товариств, тобто Закон України «Про кооперацію» та Закон України «Про споживчу кооперацію», не враховують положення Цивільного кодексу України щодо розподілу товариств на підприємницькі та непідприємницькі, а в деяких статтях навіть суперечать йому. Зокрема, Закон України «Про кооперацію» надає право учасникам усіх кооперативів незалежно від їх виду отримувати частину прибутку, одержаного в результаті діяльності товариств, хоча стаття 23 цього Закону встановлює: виробничі кооперативи провадять господарську діяльність 3 метою одержання прибутку. Інші кооперативи надають послуги своїм членам, не маючи на меті одержання прибутку [7, с. 134].

Закон України «Про споживчу кооперацію» у статті 6 зазначає, що член споживчого товариства має право одержувати частину прибутку, що розподіляється за результатами господарської діяльності між членами споживчого товариства відповідно до їх пайового внеску. Проте споживчі товариства відповідно до норм Цивільного кодексу України не повинні розподіляти отриманий прибуток між учасниками. Невідповідність норм нашого законодавства приводить до неоднозначнос- 
ті щодо визначення характеру діяльності споживчих товариств, тоді як тлумачення неприбуткового характеру споживчих товариств є надзвичайно важливим, оскільки забезпечує збереження унікального виду кооперативного утворення, яке має на меті підвищити життєвий рівень громадян та забезпечити реальну демократичність нашого суспільства.

В основу розподілу товариств на підприємницькі та на непідприємницькі закладена мета отримання прибутку та можливість розподілу цього прибутку між учасниками товариства. Але на практиці доволі важко визначити, коли отримання прибутку є основною метою, а коли засобом досягнення основної мети. Тому розмежувати ці види товариств можна за можливістю вільного розподілу прибутку між учасниками товариства.

Стаття 86 Цивільного кодексу України надає можливість непідприємницьким товариствам здійснювати підприємницьку діяльність і отримувати прибуток у передбачених законом випадках, проте аналіз статті 85 Цивільного кодексу України свідчить, вони не можуть вільно розподіляти прибуток між своїми учасниками.

Стаття 86 Цивільного кодексу України вказує, що споживчі товариства належать саме до непідприємницьких товариств, обгрунтуванням чого $є$ те, що споживче товариство здійснює некомерційну господарську діяльність, а не підприємницьку. Відповідно до статті 42 Господарського кодексу України підприємництво - це самостійна, ініціативна, систематична, на власний ризик господарська діяльність, що здійснюється суб'єктами господарювання (підприємцями) з метою досягнення економічних і соціальних результатів та одержання прибутку. Метою ж споживчого товариства є збільшення доходів для поліпшення добробуту своїх членів, зменшення їх видатків на споживання, що відображає собою неприбуткову природу діяльності цих кооперативних утворень.

Споживче товариство має особливий статус. Воно є неприбутковою організацією, що створена для взаємної допомоги членів-клієнтів. Проте отримання доходу, частина якого фактично є прибутком, не може бути класифікаційною ознакою, що визначає належність цієї організації до прибуткових організа- 
цій. Він зауважує, що лише кінцева мета організації визначає, чи $є$ вона орієнтованою на отримання прибутку, чи має зовсім інші наміри, а прибуток $є$ лише засобом здійснення цих намірів.

Інший теоретик О. Чаянов стверджував: «Кооператив буде надзвичайно корисним, якщо він навіть не буде приносити жодного чистого прибутку як підприємство, але зате збільшить доходи своїх членів. І навпаки, кооператив буде шкідливим, якщо, наприклад, він дає 10 тисяч прибутку, але завдяки його невмілому веденню селяни недоодержать 40 тисяч свого трудового доходу. Успіх кооперації вимірюється зростанням доходів іiі членів, а не прибутками самого кооперативу, є дохід його членів і більше нічого» [7, с. 135].

Проте, як зауважує В.І. Семчик, «неприбутковість» термін не тотожний терміну «безприбутковість» [8]. А відсутність у споживчого товариства будь-якого прибутку від здійснення ним некомерційної господарської діяльності призведе до того, що таке товариство не витримає конкуренції з суб'єктами підприємницької діяльності.

Кучеренко I. М., характеризуючи таку організаційно-правову форму товариств, як непідприємницькі кооперативи, до яких відносяться і споживчі товариства, виділяє такі істотні ознаки такої організаційно-правової форми: члени таких кооперативних товариств $є$ власниками паю в пайовому фонді і несуть повну відповідальність за зобов'язаннями кооперативу. Наведені ознаки є саме тими цивільно-правовими характеристиками, що відображають особливості правового статусу непідприємницьких кооперативів загалом [9, с. 52].

Виділяючи таку організаційно-правову форму, як споживче товариство, треба визначити ті ознаки, що є характерні тільки для споживчих товариств. До істотних ознак організаційно-правової форми юридичних осіб приватного права вчені відносять: об'єкти права власності учасників юридичної особи або майнові права засновників юридичної особи; ступінь відповідальності учасників за зобов'язаннями юридичної особи.

Ознакою, що визначає організаційно-правову форму споживчих кооперативних товариств, є об'єкти права власності їх членів. Ця ознака Законом України «Про споживчу кооперацію» 
визначена неналежним чином, адже відповідно до пункту 1 статті 9 Закону об'єктом права власності членів споживчого товариства є частка в його майні. Таке визначення об'єктів права власності слід оцінити критично з огляду на те, що суб'єктом права власності виступають не члени товариства, а безпосередньо споживче товариство. Все майно, внесене пайовиками, належить тільки споживчому товариству. Тому об'єктом права власності членів споживчого товариства $є$ пай. Стаття 2 Закону України «Про кооперацію» визначає пай як майновий поворотний внесок члена кооперативу у створення та розвиток кооперативу, який здійснюється шляхом передачі кооперативу майна, в тому числі грошей, майнових прав, а також земельної ділянки [5].

Згідно $з$ положеннями Програми завершення розмежування i закріплення власності в споживчій кооперації України (Укоопспілки) від 19 грудня 2000 року власник паю має право розпоряджатися ним (продавати, дарувати передавати у спадщину) [10].

Однією з ознак споживчого кооперативного товариства, що носить цивілістичний характер, є відповідальність його членів.

Частина 3 статті 6 Закону України «Про споживчу кооперацію» встановлює, що члени товариства несуть відповідальність за зобов'язаннями споживчого товариства в межах пайового внеску членів товариства. Стаття 27 Закону України «Про кооперацію» встановлює відповідальність членів кооперативу за його зобов'язаннями в межах внесеного ними паю, якщо інше не передбачено статутом кооперативу чи законом.

Висновки. Розглянуті цивілістичні ознаки споживчих кооперативних товариств, а саме: непідприємницький правовий статус; пай як об'єкт права власності; майнові права членів споживчого товариства на пай; відповідальність членів споживчого товариства в межах вартості паю, визначають їх як окрему організаційно-правову форму непідприємницьких кооперативних товариств.

Тому можна запропонувати таке визначення споживчого кооперативного товариства як непідприємницького кооперативного товариства, члени якого мають право власності на пай, розмір якого визначається як сукупність пайових та додаткових 
внесків, несуть відповідальність у межах вартості паю та мають право отримувати прибуток у межах, встановлених законом.

\section{Список використаних джерел}

1. Конституція України: прийнята на п’ятій сесії Верховної Ради України 28.06.1996 p. URL: http://zakon4.rada.gov.ua/laws/show/254к/96-вp (дата звернення: 28.10.2020).

2. Про споживчу кооперацію: Закон України від 10.04.1992 р. № 2265. URL: http://zakon3.rada.gov.ua/laws/show/236/96-вр (дата звернення: 28.10.2020).

3. Цивільний кодекс України від 16.01.2003 р. № 435-IV. URL: http://zakon4.rada.gov.ua/laws/show/435-15 вата звнення: 28.10.2020).

4. Господарський кодекс України від 16.01.2003 p. № 436-IV. URL: http://zakon3.rada.gov.ua/laws/show/436-15 (дата звернення: 28.10.2020).

5. Про кооперацію: Закон України від 10.07.2003 p. № 1087. URL: http://zakon3.rada.gov.ua/laws/show/236/96-вp (дата звернення: 28.10.2020).

6. Апотій В. В., Міщук І. Організація торгівлі. Київ, 2005. 150 с.

7. Зеліско А. В. Споживчі товариства як вид непідприємницьких товариств. Часопис Хмельницького університету управління та права «Університетські наукові записки». 2005. № 4 (16). С. 132-136.

8. Кооперативне право: підручник для кооперат., сільськогосп., економ., юрид. вищ. навч. закладів і фак. / за ред. чл.-кор. НАН України В.І. Семчика. Київ, 1998. 366 с.

9. Кучеренко I. М. Місце споживчих товариств у системі непідприємницьких кооперативів. Часопис Хмельницького університету управління та права «Університетські наукові записки». 2005. № 3. С. 52-59.

10. Програма завершення розмежування і закріплення власності в споживчій кооперації України (Укоопспілки): затверджено постановою XVIII (позачергового) з’їзду споживчої кооперації України 19.12.2000 р. зі змінами і доповн., затверд. IV зборами Ради Укоопспілки XIX скликання 24.01.2007 р. Нормативні акти Укоопспілки: у 2 т. Т. 1. Київ: Комп'ютерпрес, 2008. С. 209-283.

Nishchymna S., Zlyvko S., Sykal M.

\section{CONSUMER PARTNERSHIPS AS ORGANIZATIONAL AND} LEGAL FORM OF A JURIDICAL ENTITY

The status of a consumer partnership as one of organizational and legal forms of juridical entities, that is also one of organizational and legal forms of citizens' 
more active participation in state-management and their personal needs satisfaction is determined in the article.

The norms of the Civil Code and the State Code of Ukraine, the Law of Ukraine "On Cooperation" and the "On Consumer Cooperation" are analyzed. According to the mentioned documents an independent, democratic citizens' organization who unite in order to conduct common management for the sake of improving their economic and social status on the basis of voluntary partnership and mutual support are considered to be a consumer partnership.

The above mentioned regulatory legal acts provide for different features of consumer partnerships. The features of consumer partnerships provided by current legislation are not civil and legal in their nature. Such a situation has become a legacy of the fact that the principles of legal regulation of the system of consumer partnerships, formed in the USSR, has not almost been changed yet. The very fact is that there is a need to develop a new legal model of consumer partnerships, which structure will take into account modern tendencies of the development of European legislation.

It's possible to formulate a list of civil and legal features of consumer cooperative partnerships that will distinguish them among any other partnerships. Namely they are: non-entrepreneurial legal status of consumer partnership; sufficiency of the main rights of the members of a partnership; subjects of property right of the members of a partnership; responsibility of the members of a partnership for obligations of a consumer partnership. All these features allow us to distinguish consumer partnerships as a separate organizational and legal form of non-entrepreneurial partnerships.

The following definition of a consumer cooperative partnership can be proposed: it is a non-entrepreneurial cooperative partnership which members have a right for a concern. The size of this concern is determined as a set of unit and additional contributions. The members are liable within the value of the unit and are entitled to profit within the limits determined by law.

Key words: cooperative, consumer partnership, features of consumer partnerships.

\section{References}

1. Constitution of Ukraine (1996), Law of Ukraine, Verkhovna Rada of Ukraine, Kyiv, available at: http://zakon4.rada.gov.ua/laws/show/ 254к/96-вр (accessed: 28.10.2020).

2. Ukraine (1992), On Consumer Cooperation: Verkhovna Rada of Ukraine, Kyiv, available at: http://zakon3.rada.gov.ua/laws/show/236/96вp (accessed: 28.10.2020).

3. Ukraine (2003), Civil Code of Ukraine: Law of Ukraine, Verkhovna Rada of Ukraine, Kyiv, available at: http://zakon4.rada.gov.ua/laws/ show/435-15 (accessed: 28.10.2020). 
4. Ukraine (2003), Economic Code of Ukraine: Law of Ukraine, Verkhovna Rada of Ukraine, Kyiv, available at: http://zakon3.rada.gov.ua/laws/show/436-15 (accessed: 28.10.2020).

5. Ukraine (2003), On Cooperation: Law of Ukraine, Verkhovna Rada of Ukraine, Kyiv, available at: http://zakon3.rada.gov.ua/laws/show/ 236/96-вр (accessed: 28.10.20209).

6. Apotii, V. and Mishchuk, I. (2005), Trade Organization, Kyiv.

7. Zelisko, A. V. (2005), "Consumer partnerships as a kind of a nonentrepreneurial partnerships", Journal of Khmelnytskyi University of Management and Law "University Scientific Notes", No 4 (16), pp. 132-136.

8. Semchyk, V. I. (1998), Cooperative Law. Textbook for cooperatives, agricultural, economics, law higher educational establishments and faculties, Kyiv.

9. Kucherenko, I. M. (2005), "Place of consumer partnerships in the system of non-entrepreneurial cooperatives", Journal of Khmelnytskyi University of Management and Law "University Scientific Notes", No 3, pp. 52-59.

10. Ukraine (2000), "The program of completing demarcation and consolidation of property in consumer cooperation of Ukraine (UOOO)", Legislative acts of UOOO, In 2 volumes, Kyiv, Vol. 1, pp. 209-283. 
УДК 347.63

DOI 10.32755/sjlaw.2020.02.040

Шамрук Н. Б., кандидат юридичних наук, заступник начальника кафедри адміністративного, цивільного та господарського права і процесу, Академія Державної пенітенціарної служби, м. Чернігів, Україна ORCID: 0000-0001-9308-3754;

Кульок Д. М., слухач магістратури Академії Державної пенітенціарної служби,

м. Чернігів, Україна

ORCID: 0000-0003-2470-2122

\section{ЩОДО ОСОБИСТИХ НЕМАЙНОВИХ ТА МАЙНОВИХ ПРАВ І ОБОВ'ЯЗКІВ БАТЬКІВ ТА ДІТЕЙ У ЗАКОНОДАВСТВІ УКРАЇНИ}

У статті надана загальна характеристика поняття особистих немайнових та майнових прав і обов'язків батьків та дітей у сучасних умовах в Украӥні. Зазначено, щуо законодавство надає поняття майновим та немайновим правам та обов'язкам батьків та дітей у державі та, відповідно, врегульовує ичим самим вищевказані взаємини між ними. У висновках зазначено, щу необхідно поглиблювати вивчення цих понять для подальшого їх удосконалення $і$ трунтовних тлумачень, при цуьому враховуючи всі зміни до законодавства, судову практику, думку науковців та зміни, щуо стосуються суспільного життя.

Ключові слова: батьки, діти, особисті немайнові права, особисті немайнові обов 'язки, особисті майнові права, особисті майнові обов'язки.

Постановка проблеми. Особисті немайнові та майнові права і обов'язки батьків та дітей посідають важливе місце у сукупності всіх відносин, що виникають у сім'ї. Спочатку вони отримали закріплення в традиціях, національних звичаях, нормах моралі, релігійних канонах, згодом стали предметом регулювання та охорони норм законодавства, зокрема сімейного та цивільного. Ці відносини завжди привертали до себе увагу науковців, та в юридичній науці питанню батьківських правовідносин останнім часом не достатньо приділялося належної уваги. Але на сьогодні дослідження їх не втрачає своєї актуальності, що пояснюється постійною зміною відносин у сучасному суспільстві, появою нових способів і форм спілкування, які впливають на захист і реалізацію особистих немайнових та майнових прав і обов'язків батьків та дітей, а тому існує гостра потреба розглянути вищезазначене питання. 
Аналіз останніх досліджень і публікацій. Правовідносинам, що формуються між батьками та дітьми, були присвячені окремі праці М. В. Антокольської, Ю. Ф. Беспалова, Є. М. Білогорської, В. І. Бошко, Я. Р. Веберса, Є. М. Ворожейкіна, В. С. Гопанчука, В. І. Даніліна, І. В. Жилінкової, Р. П. Мананкової, Г. К. Матвеева, В.Ф. Маслова, Я. М. Шевченко та інших.

Метою статті $\epsilon$ загальна характеристика правовідносин батьків та дітей: визначення поняття, аналіз видів та особливостей особистих немайнових та майнових прав і обов'язків батьків та дітей у сучасних умовах в Україні.

Виклад основного матеріалу. Особистим немайновим правам і обов'язкам батьків та дітей приділяється окрема глава Сiмейного кодексу України (далі - СК України) [1]. Так, у ст. 141 СК України визначено принцип рівності прав та обов'язків батьків щодо дитини, який закріплює рівність прав і обов'язків мати та батька щодо дитини незалежно від того, чи перебували вони у шлюбі між собою, а розірвання шлюбу між батьками та проживання їх окремо від дитини не впливає на обсяг їхніх прав та не звільняє їх від виконання обов'язків стосовно дитини. Взаємини батьків і дітей мають грунтуватися на повазі до прав дитини та іiі людської гідності, а тому батьківські права не можуть здійснюватися всупереч інтересам дитини [2, с. 51].

Аналізуючи Главу 13 СК України «Особисті немайнові права і обов'язки батьків та дітей», можна виділити такі основні особисті немайнові батьківські права: 1) право на визначення дитині прізвища, імені, по батькові; 2) право на зміну прізвища та по батькові малолітньої дитини; 3) право на виховання дитини; 4) право на спілкування 3 дитиною; 5) право на представництво і захист прав та інтересів дитини; 6)право на визначення місця проживання малолітньої дитини; 7) право на відібрання малолітньої дитини від інших осіб; 8) право на піклування та турботу про себе зі сторони повнолітніх дітей. Крім того, варто додати до цього переліку й особисте право батьків давати згоду на усиновлення своєї дитини іншою особою, яке закріплено в ст. 217 СК України.

Особисті немайнові права дитини також можуть бути піддані певному групуванню (класифікаціi). Аналіз Глави 13 СК 
України, яка закріплює особисті немайнові права й обов'язки батьків і дітей, дозволяє виділити такі особисті немайнові права дитини, як: 1) право на визначення прізвища, імені, по батькові; 2) право на зміну прізвища та по батькові; 3) право на належне батьківське виховання; 4) право на захист своїх прав та інтересів; 5) право на спілкування з батьками; 6) право на визначення місця проживання; 7) право висловити свою думку і бути вислуханою з питань, що стосуються іiї особисто, та питань сім’ї.

Отже, під особистими немайновими правами батьків законодавець розуміє суб'єктивні права матері та батька, що надають можливість їх носіям мати і здійснювати немайнові права у пріоритетному порядку перед іншими учасниками сімейних правовідносин, під особистими немайновими правами дитини визначає суб'єктивні особисті права, об'єктом яких є нематеріальні блага, які виникають із народження й припиняються 3 досягненням повної дієздатності, спрямовані на нормальний розвиток і соціалізацію дитини, мають високий ступінь публічного інтересу, що полягає в здійсненні контролю за діями батьків або осіб, що їх замінюють.

Аналізуючи обов'язки батьків, варто наголосити, що, ст. 143 СК України зобов'язує батьків забрати дитину з пологового будинку або іншого закладу охорони здоров'я. Саме цей обов'язок батьків забрати дитину з пологового будинку є необхідною передумовою для здійснення ними всіх інших особистих немайнових прав щодо дитини. Проте ст. 143 СК України чітко визначає юридичні підстави, що можуть звільнити батьків від виконання цього обов'язку. Ними є, по-перше, наявність у дитини істотних вад фізичного й (або) психічного розвитку, по-друге, наявність інших обставин, які мають істотне значення [1].

Іншим немайновим обов'язком батьків стосовно дітей є реєстрація народження дитини в органі Державної реєстрації актів цивільного стану (ст. 144 СК України). В разі коли батьки чи один із них не досягли 18-річного віку, народження дитини реєструється у звичайному порядку. Також варто підкреслити, що реєстрація народження здійснюється з одночасним присвоєнням імені по батькові та прізвища дитині [3, с. 70]. 
Особливий теоретичний і практичний інтерес становить аналіз особистих немайнових обов'язків батьків щодо виховання дітей. Так, згідно зі ст. 150 СК України, саме батьки зобов'язані надавати дитині належне батьківське виховання. Стаття 12 Закону України «Про охорону дитинства» та ст. 150 СК України наголошують, що виховання в сім’ї є першоосновою розвитку особистості дитини. На кожного із батьків покладається однакова відповідальність за виховання, навчання та розвиток дитини. Батьки (особи, які їх замінюють) зобов’язані виховувати дитину, піклуватися про іiі здоров'я, фізичний, духовний i моральний розвиток, навчання, створювати належні умови для розвитку їі природних здібностей, поважати гідність дитини, готувати їі до самостійного життя та праці. Натомість, варто підкреслити, що обов'язок повнолітніх дочки/сина піклуватися про своїх непрацездатних батьків закріплено в ст. 51 Конституції України. Така конституційна норма отримує своє продовження і в нормах сімейного законодавства, зокрема, ст. 172 СК України закріплює обов'язок дочки/сина піклуватися про батьків, виявляти турботу та надавати їм допомогу [1]. Слід зазначити, що виконання обов'язку піклуватися про батьків і надавати їм допомогу не завжди пов'язане із грошовими витратами, адже допомога може надаватися матері, батькові у вигляді виконання певної хатньої роботи, роботи на присадибній ділянці, прибудинковій території тощо.

Майнові права батьків і дітей - це права матері, батька, дитини, які виникають стосовно винятково майнових благ. Стаття 173 СК України зазначає, що батьки і діти, зокрема, ті, які спільно проживають, можуть бути самостійними власниками майна. В разі спору між батьками та малолітніми, неповнолітніми дітьми, які проживають разом, щодо належності їм майна вважається, що воно $є$ власністю батьків, якщо інше не буде встановлено судом. Згідно з ч. 1 ст. 177 СК України батьки управляють майном, належним малолітній дитині, без спеціального на те повноваження [1]. Отже, узагальнюючи вищевикладене, можна виділити такі види майнових прав батьків: право батьків на надання їм допомоги з боку дітей і повнолітніх дітей, право власності батьків на майно, право батьків на управління майном малолітньої дитини. 
Щодо майнових прав дітей необхідно також зазначити, що поняття «майнові права дітей» вживається законодавцем у назві Закону України від 12.01.2012 № 4314-VI «Про внесення змін до деяких законодавчих актів України щодо посилення захисту майнових прав дітей» [4], проте законодавець чомусь не надає майновим правам дітей чіткого тлумачення, а за змістом закону можна дійти висновку, що під майновими правами дітей розуміється як право власності дитини на майно (в тому числі на нерухоме майно), так і право користування ним.

Аналіз правових актів надає підстави виділити такі майнові права дитини, закріплені СК України: 1) право власності дитини на майно; 2) право дитини на користування майном батьків для забезпечення виховання та розвитку; 3) право дитини на утримання від батьків.

Обов'язок батьків утримувати дітей передбачений ст. 51 Конституції України та СК України. Згідно зі ст. 180 СК України батьки зобов'язані утримувати дитину до досягнення нею повноліття [1]. Так, відповідно до законодавства України, батьки зобов'язані: 1) утримувати своїх повнолітніх непрацездатних дочку, сина, які потребують матеріальної допомоги, якщо вони можуть таку матеріальну допомогу надавати; 2) утримувати повнолітніх дочку, сина до досягнення ними двадцяти трьох років, які продовжують навчання і у зв'язку з цим потребують матеріальної допомоги за умови, що батьки можуть надавати матеріальну допомогу [1].

Отже, законодавець чітко встановив, що батьки повинні утримувати своїх неповнолітніх дітей і непрацездатних повнолітніх дітей, які потребують матеріальної допомоги, не залежно від того, чи перебувають вони у шлюбі чи ні (у випадку народження дитини під час фактичних шлюбних відносин), чи визнаний шлюб недійсним, чи позбавлені вони батьківських прав, чи дитина від них відібрана тимчасово без позбавлення батьківських прав. Способи виконання батьками обов'язку утримувати дитину визначаються за домовленість між ними, або за рішенням суду.

Такий обов'язок виникає лише за наявності сукупності таких юридичних фактів: 1) кровне споріднення (незалежно від добровільного чи судового встановлення батьківства) чи наяв- 
ність родинних відносин (усиновлення) між батьками та дитиною; 2) непрацездатність повнолітньої особи і у зв'язку з цим брак власних коштів для задоволення своїх потреб; 3) потреба повнолітньої дитини у матеріальній допомозі; 4) можливість батьків надавати таку матеріальну допомогу [5, с. 13].

Іншим випадком, коли батьки зобов'язані утримувати своїх повнолітніх дітей, є продовження дитиною навчання. Так, згідно 3 роз'ясненнями, викладеними в п. 20 постанови Пленуму Верховного Суду України від 15 травня 2006 року № 3, обов’язок батьків утримувати повнолітніх дітей, які продовжують навчання, виникає за наявності сукупності таких юридичних фактів: 1) кровне споріднення (незалежно від добровільного чи судового встановлення батьківства) чи наявність родинних відносин (усиновлення) між батьками та дитиною; 2) продовження навчання повнолітньою дитиною; 3) потреба дитини в матеріальній допомозі; 4) можливість батьків надавати повнолітній дитині матеріальну допомогу [6].

Обов'язок батьків надавати матеріальну допомогу триває лише до досягнення дитиною 23 років і не може бути продовжений, а право на утримання припиняється у разі припинення навчання. Якщо навчання було припинене і знову відновлене, повнолітній може знову вимагати від батьків утримувати його протягом терміну продовження навчання [5, с. 14].

Таким чином, майнові обов'язки батьків можна визначити як сукупність передбачених законом юридичних обов'язків, які виникають у батьків, з моменту народження до досягнення нею повноліття, а також можуть продовжуватись у разі продовження нею навчання за умови можливості надання батьками такої допомоги.

3 іншого боку, розкриваючи майнові обов'язки дітей слід зазначити наступне. Утримання непрацездатних батьків може виражатися як у наданні матеріальної допомоги, так і виконанні дій, спрямованих на забезпечення їх життєво необхідних потреб. В Україні надання батькам матеріальної допомоги з боку повнолітніх дочок та синів здійснюється в добровільному, договірному чи в примусовому (судовому) порядку. Вибір дітей щодо обрання способу утримання своїх батьків у більшості ви- 
падків характеризуються альтернативністю і, здебільшого, здійснюється без примусу, з їх власної ініціативи [7, с. 8].

Обов'язок повнолітніх дітей утримувати своїх батьків виникає на підставі складу юридичних фактів: а) наявність сімейних відносин; б) досягнення дочкою/сином повноліття; в) непрацездатність або немічність батьків; г) потреба батьків у матеріальній допомозі.

Таким чином, майнові обов'язки дітей - це обов'язки, які виникають у повнолітніх дітей та пов'язані з надання матеріального утримання батькам, які є непрацездатними, інвалідами, чи тяжкохворими та потребують матеріальної допомоги.

Висновки. Враховуючи вищевикладене, можна дійти висновків про те, що законодавство України надає поняття майновим і немайновим правам та обов'язкам батьків і дітей у державі та, відповідно, врегульовує цим самим вищевказані відносини між ними. Так, законодавством визначено, що особисті немайнові права батьків - це суб'єктивні права матері, батька дитини, що надають можливість їх носіям мати та здійснювати немайнові права у пріоритетному порядку перед іншими учасниками сімейних правовідносин. Тобто в підтексті цього поняття ми вбачаємо всі моральні якості людини як батьків. Проте на практиці, через суспільну думку, є дуже довготривалим і клопітким процесом збір доказів про можливе недотримання цих прав та, порівняно, малий відсоток звернення суб'єктів зазначених правовідносин до органів влади щодо їх врегулювання. В свою чергу, немайнові обов'язки батьків - це визначені нормами сімейного законодавства сукупність юридичних обов'язків, які покладаються на батьків 3 моменту народження дитини та спрямовані на забезпечення прав та інтересів дитини. В цьому випадку законодавець чітко врегулював і зазначив, що саме входить до немайнових обов'язків батьків перед своїми дітьми та виклав це у розділі Сімейного кодексу України.

Особисті немайнові права дитини - це суб'єктивні права, що належать дитині з моменту народження або до досягнення нею повноліття, об’єктом яких є особисті блага. Деякі із вказаних законодавством прав можуть бути змінені суб'єктами пра- 
вовідносин по досягненню повноліття (наприклад, зміна ім'я, прізвища, по батькові, місця проживання).

Немайнові обов'язки дітей - це юридичні обов'язки, передбачені нормами сімейного права, які полягають у наданні дитиною, дочкою та сином піклування про батька та матір, якщо вони є непрацездатними, немічними або внаслідок свого похилого віку, тяжкої хвороби або каліцтва не можуть самостійно забезпечувати умови свого життя, потребують стороннього догляду, допомоги.

Майнові права батьків та дітей - це права матері, батька, дитини, які виникають стосовно майнових благ. Майнові обов'язки батьків - це сукупність передбачених законом юридичних обов'язків, які виникають у батьків, з моменту народження до досягнення нею повноліття, а також можуть продовжуватись у разі непрацездатності повнолітньої дитини чи продовження нею навчання за умови можливості надання батьками такої допомоги. Майнові обов'язки дітей - це обов'язки, які виникають у повнолітніх дітей та пов'язані з наданням матеріального утримання батькам, які є непрацездатними, інвалідами, чи тяжко хворими та потребують матеріальної допомоги.

Ці поняття розкривають усі можливості батьків та дітей, які їм надає законодавець для вирішення спірних питань, та врегульовують правовідносини між ними. Проте вважаємо, що необхідно більш поглиблювати вивчення цих понять для подальшого їх удосконалення і детальнішого надання визначення, при цьому враховуючи всі зміни до законодавства, судову практику, думку науковців та зміни, що стосуються суспільного життя.

\section{Список використаних джерел}

1. Сімейний кодекс України: Закон України від 10.01.2002 № 2947-III. Відомості Верховної Ради Украӥни від 31.05.2002, № 21. Ст. 135.

2. Темникова Н. А. Реализация и защита личных неимущественных прав ребенка в семейном праве России: дис. ... кандидата юрид. наук: 12.00.03. Омск, 2006. 197 с.

3. Дутко А. О. Сімейно-правовий статус батьків, які не досягли повноліття. Юридичний науковий електронний журнал. 2019. № 1. C. $68-71$. 
4. Про внесення змін до деяких законодавчих актів України щодо посилення захисту майнових прав дітей: Закон України від 12 січня 2012 р. № 4314-VI. Відомості Верховної Ради України. 2012. № 40. Ст. 475.

5. Кацюба К. В., Конюхова М. В. Виконання юридичного обов'язку батьків піклуватися про своїх повнолітніх дітей. Підприємниитво, господарство і право. 2019. № 6. С. 12-18.

6. Про застосування судами окремих норм Сімейного кодексу України при розгляді справ щодо батьківства, материнства та стягнення аліментів: постанова Пленуму Верховного Суду України. URL: https://zakon.rada.gov.ua/laws/show/v0003700-06. (дата звернення: 01.09.2020).

7. Лук'янчук О. І. Обов'язок дітей утримувати батьків за сімейним законодавством України: автореф. дис. ... канд. юрид. наук: 12.00.03. Нац. акад. внутр. справ. Київ, 2019. 18 с.

Shamruk N., Kuliok D.

\section{ON PERSONAL NON-PROPERTY AND PROPERTY RIGHTS AND RESPONSIBILITIES OF PARENTS AND CHILDREN IN LEGISLATION OF UKRAINE}

The article presents a general description of the concept of personal nonproperty and property rights and responsibilities of parents and children in latest conditions in Ukraine. The legislation is noted to provide the concept of property and non-property rights and responsibilities of parents and children in the state and, accordingly, to regulate such relations between them.

Under the personal non-property rights of parents the legislator understands the subjective rights of mother and father, enabling their holders to have and exercise non-property rights as a priority over other participants in family relations, the personal non-property rights of the child defines subjective personal rights, the object of which is intangible benefits that arise from birth and cease to reach full capacity, aimed at the normal development and socialization of the child, have a high degree of public interest, which is to control the actions of parents or persons replacing them.

Special attention in the article is paid to the property responsibilities of parents and children. It is established that the property responsibilities of parents are a set of statutory legal obligations that arise for parents from birth to adulthood, and may continue in the event of incapacity of an adult child or continued education, provided that parents can provide such assistance, and accordingly the property responsibilities of children - are the obligations that arise in adult children and related to the provision of material support to parents who are unable to work, disabled, or seriously ill and in need of financial assistance.

In our opinion, these concepts reveal almost all the opportunities provided by parents and children, which are provided by the legislator to resolve disputes and 
regulate the legal relationship between them. However, we believe that it is necessary to deepen the study of these concepts to further improve them and provide a more detailed definition, while considering all changes in legislation, case law, the opinion of scholars and changes in public life.

Key words: parents, children, personal non-property rights, personal nonproperty responsibilities, personal property rights, personal property responsibilities.

\section{References}

1. Ukraine (2002), Family Code of Ukraine: Law of Ukraine dated January 10, 2002 №2947-III: The Verkhovna Rada of Ukraine dated 31.05.2002, № 21, Art. 135.

2. Temnikova, N. (2006), Realization and protection of personal nonproperty rights of the child in family law of Russia: autoref. dis ... cand. yurid. nauk: 12.00.03. Omsk.

3. Dutko, A. (2019), "Family law status of parents who have not reached the age of majority", Legal scientific electronic journal, № 1, pp. $68-71$.

4. Ukraine (2012), On amendments to some legislative acts of Ukraine to strengthen the protection of property rights of children: Law of Ukraine dated January 12, 2012 № 4314-VI: The Verkhovna Rada of Ukraine, № 40 , p. 475 .

5. Katsyuba, K. and Konyukhova, M. (2019), "Fulfillment of the legal obligation of parents to take care of their adult children", Entrepreneurship, economy and law, № 6, pp. 12-18.

6. On application by courts of certain norms of the Family Code of Ukraine when considering cases concerning paternity, maternity and recovery of alimony: Resolution of the Plenum of the Supreme Court of Ukraine, available at: https://zakon.rada.gov.ua/laws/show/v0003700-06.

7. Lukyanchuk, O. (2019), Obligation of children to support parents under the family legislation of Ukraine: autoref. dis .... cand. yurid. nauk: 12.00.03, National Academy of Internal Affairs, Kyiv. 


\section{АКТУАЛЬНІ ПИТАННЯ \\ АДМІНІСТРАТИВНОГО, ФІНАНСОВОГО \\ ТА ІНФОРМАЦІЙНОГО ПРАВА}

УДК 34.02

DOI 10.32755/sjlaw.2020.02.050

Ребкало М. М., кандидат наук $з$ державного управління, доцент кафедри теорії та історії держави і права, конституційного права,

Академія Державної пенітенціарної служби, м. Чернігів, Україна 0000-0002-9633-5811;

Шумна Л. П., доктор юридичних наук, доцент, завідувач кафедри теорії та історії держави і права, конституційного права, Академія Державної пенітенціарної служби, м. Чернігів, Україна 0000-0002-7708-296X;

Олійник В. С., кандидат юридичних наук, доцент кафедри теорії та історії держави і права, конституційного права, Академія Державної пенітенціарної служби, м. Чернігів, Україна 0000-0001-5546-9613

\section{ФОРМИ ПІДВИЩЕННЯ КВАЛІФІКАЦІЇ ПЕРСОНАЛУ ДЕРЖАВНОЇ КРИМІНАЛЬНО-ВИКОНАВЧОЇ СЛУЖБИ УКРАЇНИ: ПЕРЕВАГИ ТА НЕДОЛІКИ}

Стаття присвячена формам організачії прочесу підвищення кваліфікаџії персоналу Державної кримінально-виконавчої служби. Проаналізовано переваги та недоліки як зовнішньої, так і внутрішньої форм підвищення кваліфікації. Сформульовано висновки стосовно позитивності наслідків поєднання у чинному прочесі підвищення кваліфікації пенітенціарного персоналу зовнішньої та внутрішньої форм.

Ключові слова: Державна кримінально-виконавча служба Украӥни; пенітенціарний персонал; система підвищення кваліфікації персоналу; зовнішні форми підвищення кваліфікації; внутрішні форми підвищення кваліфікацї; переваги та недоліки підвищення кваліфікації персоналу.

Постановка проблеми. Зміни, що відбуваються у сфері виконання покарань, роблять актуальним завдання зі створення умов для безперервного розвитку здібностей кожного співробіт- 
ника і тому висувають нові вимоги до чинної системи професійної підготовки, складовою частиною якої є підвищення кваліфікації. Такий підхід істотно сприяє розвитку професіоналізму персоналу, інтеграція якого у процес проходження служби i, як показує практика, суттєво підвищує ефективність виконання службових обов'язків. Й тому невипадково, що протягом останнього десятиріччя проблеми організації та вдосконалення процесу підвищення кваліфікації постійно знаходяться у полі зору науковців та практичних працівників.

Аналіз останніх досліджень і публікацій. Учені, які здійснюють наукову розробку системи підвищення кваліфікації державних службовців мілітаризованого та цивільного призначення, досліджують усі сторони цієї діяльності. Так, на думку Т. Кагановської, система підготовки, перепідготовки й підвищення кваліфікації державних службовців повинна розглядатися як єдина, цілісна підсистема в системі кадрового забезпечення державного управління, від стану і рівня якої залежить ефективність і раціональність державного управління [1, с. 149].

Бутко М. одним з елементів удосконалення кадрового потенціалу в органах виконавчої влади та місцевого самоврядування вбачає в тому, щоб навчити вказану категорію осіб ефективно використовувати свої особистісні професійні резерви для задоволення потреби кожного в перепідготовці та підвищенні кваліфікації, а також створити систему етапного підвищення кваліфікації, максимально враховувати нові завдання у сфері державної служби [2, с. 43].

Чайка Л. вказує на необхідність цільового підходу під час роботи з різними категоріями державних службовців, залучення до викладання на курсах підвищення кваліфікації керівних кадрів регіональних органів, забезпечення інформаційної спрямованості змісту навчання, впровадження в цей процес різноманітних форм та ін. [3, с. 70].

Кісіль 3. вважає, що професійна підготовка персоналу органів внутрішніх справ є нормативно врегульований, організований, безперервний і цілеспрямований процес опанування спеціальними знаннями, вміннями й навичками, необхідними для успішного виконання покладених на осіб рядового та началь- 
ницького складу оперативно-службових завдань, функцій та обов'язків, а також реалізації наданих їм прав [4, с. 204].

Дука О., аналізуючи проблеми юридичної освіти персоналу кримінально-виконавчої служби, стверджує, що головним завданням цього процесу є здійснення переходу до особистісноорієнтованого навчання, спрямованого на оволодіння сучасною системою знань, умінь та навичок, способів творчої діяльності, ціннісних орієнтирів, необхідних для виконання поставлених державою завдань виправлення і ресоціалізації засуджених, підготовка їх до адаптації в умовах соціального життя після звільнення [5, с. 83].

Отже, викладені вище погляди стосовно змісту та особливостей системи підвищення кваліфікації та іiі значення для вдосконалення професіоналізму державних службовців, які проходять службу в різних державних органах, заслуговують на увагу. Але служба в органах виконання покарань $є$ особливим видом державної служби, якій притаманні специфічні завдання, і тому деталізація деяких аспектів підвищення професіоналізму персоналу в умовах приведення останнього до міжнародних пенітенціарних стандартів набуває певної актуальності.

Метою статті $є$ дослідження переваг та недоліків, чинних у сфері виконання покарань форм підвищення кваліфікації, як необхідної складової вдосконалення професійного рівня пенітенціарного персоналу.

Виклад основного матеріалу. Професійна підготовка фахівців орієнтована на особистісний розвиток і творчу самореалізацію кожного громадянина України, формування поколінь, які навчаються впродовж життя, розвивають цінності громадянського суспільства, сприяють консолідації української нації та іiї інтеграції в європейський та світовий простір [6, с. 12]. Упродовж цього професійна підготовка персоналу, який працює у сфері виконання покарань, має забезпечити отримання та вдосконалення останнім професійних знань, спеціальних умінь i навичок, необхідних для успішного виконання службових обов'язків. Такий підхід спонукав свого часу керівництво Державної кримінально-виконавчої служби України виступити 3 ініціативою нормативного затвердження механізму навчання та 
підвищення кваліфікації персоналу. Так, у ст. 17 Закону України «Про Державну кримінально-виконавчу службу України» зазначено, що підготовка, перепідготовка, підвищення кваліфікації персоналу Державної кримінально-виконавчої служби України проводяться відповідно до законодавства про освіту. 3 цією метою Державна кримінально-виконавча служба України може створювати відповідні навчальні заклади, а також організовувати підготовку фахівців в інших навчальних закладах на договірній основі [7].

У Положенні про організацію професійної підготовки осіб рядового і начальницького складу Державної кримінальновиконавчої служби України, яке затверджене наказом Міністерства юстиції України (далі - Положення), визначено зміст підвищення кваліфікації як процес набуття особами рядового і начальницького складу додаткових знань та навичок щодо виконання завдань та обов'язків у межах спеціальності. Відповідно до зазначеного Положення підвищення кваліфікації проходять особи рядового і начальницького складу, які мають професійно-технічну або вищу освіту. Підвищення кваліфікації проводиться у вищих навчальних закладах кримінальновиконавчої служби, вищих навчальних закладах та закладах післядипломної освіти, підпорядкованих іншим центральним органам виконавчої влади, місцевим органам влади, не рідше ніж один раз у п'ять років [8].

Отже, чинна система підвищення кваліфікації пенітенціарного персоналу побудована на основі вимог кримінальновиконавчого законодавства та регламентована за своїм змістом.

Викладена у Положенні структура підвищення кваліфікації персоналу дозволяє зробити висновок про те, що цей освітянський процес реалізується у двох формах:

- по-перше, в навчальних закладах центральних органів виконавчої влади та місцевих органів виконавчої влади (зовнішня форма);

- по-друге, в навчальних закладах Державної кримінальновиконавчої служби (внутрішня форма).

Зовнішня форма підвищення кваліфікації працівників здійснюється в закладах центральних органах виконавчої влади, а 
також у спеціалізованих інститутах (центрах) підвищення кваліфікації, що функціонують у регіонах. Так, тільки у м. Чернігові діє Інститут післядипломної педагогічної освіти імені К. Д. Ушинського. У складі цього закладу створено факультет підвищення кваліфікації та обласний центр практичної психології й соціальної роботи. Факультет підвищення кваліфікації забезпечує й реалізує освітні програми підвищення кваліфікації педагогічних працівників 3 метою збагачення їх професійних знань, подолання розриву між раніше отриманою ними фаховою підготовкою й новими вимогами до освіти держави й конкретного регіону. Пріоритетними напрямами Обласного центру практичної психології та соціальної роботи визначено: підвищення ефективності управління психологічною службою, покращення методичного забезпечення діяльності працівників психологічної служби, підготовка і підвищення кваліфікації працівників психологічної служби й інше. Ще одним суб'єктом у сфері підвищення кваліфікації є Чернігівський центр перепідготовки та підвищення кваліфікації працівників органів державної влади, органів місцевого самоврядування, керівників державних підприємств, установ і організацій. До його компетенції входить надання послуг 3 післядипломної освіти державним службовцям, посадовим особам місцевого самоврядування, працівникам підприємств, установ, організацій науково-методичної, інформаційної і консультаційної допомоги. В зазначених вище закладах мають можливість підвищувати кваліфікацію викладацький склад Академії Державної пенітенціарної служби, соціальні педагоги і психологи установ виконання покарань та пробації та деякі категорії державних службовців, які працюють в установах та закладах кримінально-виконавчої служби.

Системи підвищення кваліфікації в регіональних інститутах (центрах) реалізується через різні моделі. $Є$ моделі, які забезпечують єдність змісту освітнього процесу та адекватних йому навчальних технологій. В інших моделях пропонується введення варіативного підходу, де розробляється певна сторона професії, яка потребує вдосконалення. Цінність останньої моделі полягає в тому, що вона забезпечує розвиток професійної компетентності з урахуванням наявного рівня індивідуальної підго- 
товки особи. Тому варіативний підхід дає можливість застосування ступеневої системи безперервного підвищення кваліфікації, яка позитивно впливає на результати навчання. Інститути (центри) підвищення кваліфікації використовують також модель, яка побудована на основі діагностики. Сутність останньої полягає в тому, що в навчанні слухачів самоаналізу, узагальнення передового досвіду використовується спеціальне діагностування $з$ подальшим моніторингом набутих знань. Практика показує, що ця модель ефективна в умовах постійно мінливих навчальних планів, програм, навчальної літератури.

Удосконалюються й форми організації процесу підвищення кваліфікації. Крім консультативної допомоги, отримання методичних рекомендацій, проведення різних видів занять (лекцій, семінарів, практичних занять), використовуються й такі, як: аналіз конкретних практичних ситуацій, участь у дискусіях i ділових іграх, розроблення проєкту вдосконалення особистої професійної майстерності та ін. Крім того, активно застосовуються діагностика вихідного рівня підготовленості працівників, експертні оцінки, розроблення методик визначення ефективності занять та ін.

Зовнішня форма підвищення кваліфікації передбачає організацію навчального процесу на базі телекомунікаційних та інформаційних технологій, засобів Internet (дистанційне навчання). Дистанційні форми навчання мають над очними формами певні переваги, наприклад економічного, комерційного, ергономічного, інформаційного та комунікаційного характеру. Основна ідея такого навчання полягає в тому, щоб на основі активної пізнавальної та творчої діяльності слухачів сприяти розвитку комунікативних якостей, а також здатності до саморефлексії.

Отже, навчання пенітенціарного персоналу в регіональних інститутах і центрах підвищення кваліфікації, які перебувають у підпорядкуванні центральних органів виконавчої влади та органів місцевого самоврядування, дає можливість не тільки вдосконалити свій рівень знань, але й опанувати позитивним досвідом, який напрацьовано в різних сферах професійної діяльності.

Викладене вище дозволяє сформулювати такі переваги зовнішньої форми навчання: 
- гарантована можливість підвищити кваліфікацію персоналу з більшості професій, які застосовуються у кримінальновиконавчій діяльності;

- процес навчання побудований на основі апробованих практикою програм та навчальних планів;

- спроможність отримання консультативної, методичної та організаційної допомоги за обраним напрямом підвищення кваліфікації;

- можливість отримання навичок у реалізації інформаційних технологій, які застосовуються в різних професійних сферах.

Але, на нашу думку, зовнішній формі підвищення професіоналізму притаманні певні недоліки. Серед них слід виділити:

- особливості професійної діяльності персоналу органів, установ та закладів виконання покарань та пробації не завжди можуть бути враховані в повному обсязі;

- регіональні інститути і центри, як правило, орієнтовані на роботу з працівниками не мілітаризованих професій, що зменшує бажання осіб рядового та начальницького складу Державної кримінально-виконавчої служби отримати в них необхідні освітянські послуги;

- застосування рецептурного підходу в реалізації навчального процесу, при якому слухачі забезпечуються готовими сценаріями навчальних заходів або алгоритмами аналізу професійної діяльності.

Таким чином, наслідком вищевказаних недоліків стає той факт, що така система не завжди повно забезпечує потребу 3 удосконалення рівня знань та умінь, які необхідні для службової діяльності в органах установах та закладах виконання покарань.

Внутрішні форми підвищення професіоналізму співробітників - це форми роботи, які здійснюються безпосередньо в навчальних закладах Державної кримінально-виконавчої служби України. Останнім часом вони набувають усе більшого значення, оскільки можуть значною мірою задовольнити потреби кримінально-виконавчої служби із вдосконалення кадрового складу. Упродовж цього головним завданням підвищення кваліфікації $є$ розвиток професіоналізму персоналу, формування 
здатності до визначення власних професійних можливостей, зміна ставлення до службової діяльності.

Форми організації навчально-методичної роботи на курсах підвищення кваліфікації змінюються й оновлюються залежно від багатьох факторів, таких як:

- стану реалізації державної політики у сфері виконання покарання;

- рівня професійної культури персоналу;

- морально-психологічного клімату в колективах персоналу Державної кримінально-виконавчої служби;

- конкретної ситуації, яка виникає під час виконання службових завдань та ін.

Головним елементом чинної системи підвищення кваліфікації в органах, установах та закладах виконання покарань $\epsilon$ спонукання кожного слухача до усвідомлення власних потреб у зростанні своєї професійної компетентності та прагнення до вдосконалення професійної ерудиції.

Загалом у Державній кримінально-виконавчій службі України склалася стала структура органів, які забезпечують професійну підготовку осіб рядового та начальницького складу. Умовно їх можна поділити на такі дві групи:

- перша - це органи які здійснюють управління професійною підготовкою персоналу;

- друга - органи, що безпосередньо забезпечують. професійну підготовку рядового та начальницького складу.

До першої групи слід віднести структурні підрозділи Міністерства юстиції, які здійснюють управління персоналом Державної кримінально-виконавчої служби. Такі підрозділи забезпечують визначення стратегії розвитку професійної підготовки осіб рядового і начальницького складу, здійснюють контроль за дотриманням вимог нормативно-правових актів $з$ питань професійної підготовки, організують інспектування процесу організації професійної підготовки осіб рядового і начальницького складу на регіональному рівні [8].

Кадрові підрозділи регіональних органів управління Державної кримінально-виконавчої служби теж вирішують певні завдання щодо управління процесом підвищення кваліфікації. 
Серед них слід виділити: визначення потреб у професійній підготовці, перепідготовці, підвищенні кваліфікації осіб рядового і начальницького складу підрозділів, які знаходяться в їх підпорядкуванні; здійснення контролю щодо визначення рівня організації професійної підготовки та підвищення кваліфікації осіб рядового і начальницького складу; прогноз обсягів та ведення обліку професійної підготовки осіб рядового і начальницького складу за видами ії проведення та ін. [8].

До другої групи суб'єктів, що здійснюють підвищення кваліфікації, належать навчальні заклади Державної кримінальновиконавчої служби України.

Так у складі Академії Державної пенітенціарної служби утворено факультет підвищення кваліфікації персоналу ДКВС України. Зазначений структурний підрозділ Академії здійснює навчальну, методичну, наукову, організаційну та виховну роботу зі слухачами, що прибули для підвищення своєї кваліфікації 3 установ виконання покарань та слідчих ізоляторів Державної кримінально-виконавчої служби України. Освітянський процес на цьому факультеті здійснюється із врахуванням прогресивних методів, новітніх методик, сучасних інформаційних та інноваційних технологій навчання і спрямований на формування у слухачів готовності до активної службової діяльності, відповідальності за поручену справу, патріотизму та гуманізму.

Наступним суб'єктом освітянської діяльності серед працівників, які проходять підвищення кваліфікації, є Білоцерківський центр підвищення кваліфікації персоналу Державної кримінально-виконавчої служби України. Сьогодні цей навчальний заклад здійснює як первинну професійну підготовку персоналу, так і забезпечує підвищення кваліфікації персоналу установ виконання покарань та працівників пробації.

Дніпровський центр підвищення кваліфікації персоналу ДКВС України на теперішній час забезпечує навчання та підвищення кваліфікації за 24 категоріями професій, які використовуються в органах, установах та закладах Державної кримінально-виконавчої служби України.

Хмельницький центр підвищення кваліфікації персоналу ДКВС України забезпечує первинну професійну підготовку мо- 
лодших інспекторів-кінологів відділів режиму і охорони слідчих ізоляторів та відділів охорони установ виконання покарань Державної кримінально-виконавчої служби України.

Викладене вище дає можливість звернути увагу на переваги підвищення професіоналізму персоналу, які реалізуються в навчальних закладах кримінально-виконавчої служби. Головними 3 них є:

- розширення та вдосконалення професійних знань, формування вмінь і навичок у реалізації кримінально-виконавчих процесів здійснюється під керівництвом фахівців, які мають досвід практичного застосування кримінально-виконавчого законодавства;

- вдосконалення індивідуальної професійної майстерності забезпечується на основі новаторських пенітенціарних досягнень і спрямоване на виявлення, узагальнення та впровадження передового професійного досвіду;

- стимулювання прагнення кожного до підвищення свого професійного та культурного рівня та службової активності;

- вдосконалення методів і стилю взаємодії з громадськими та волонтерськими організаціями.

Така форма підвищення професійної майстерності має і такі недоліки:

- підвищенню кваліфікації підлягають, як правило, професії юридичного спрямування;

- частіше всього персонал проходить підвищення кваліфікації з відривом від виконання своїх службових обов'язків, тобто не повною мірою використовується дистанційне навчання;

- для підвищення кваліфікації залучаються особи рядового та начальницького складу, а цивільний персонал поки що недостатньо охоплюється цим процесом.

Отже, внутрішня форма підвищення кваліфікації, яка реалізується навчальними закладами Державної кримінальновиконавчої служби України, сприяє ефективному вирішенню завдання розвитку професіоналізму осіб рядового та начальницького складу, але має й певні недоліки, подолання яких має 
стати одним із завдань у процесі створення ефективної системи підвищення кваліфікації.

Висновки. Дослідження системи підвищення кваліфікації персоналу дозволяє констатувати наступне:

- по-перше, використання та дієвий процес підвищення кваліфікації зовнішньої та внутрішньої форм дає можливість удосконалити професійні знання та навички на основі сучасних наукових досягнень та передового досвіду їх застосування, що широко впроваджуються як у сфері виконання покарань, так і в інших галузях професійної діяльності суспільства;

- по-друге, згадані форми підвищення кваліфікації дозволяють удосконалити професійний рівень представників більшості професій, які є у сфері виконання покарань;

- по-третє, поєднання зовнішньої та внутрішньої форм істотно розширяє можливості впровадження в навчальний процес ефективних методик викладання, які реалізуються в навчальних закладах сфери виконання покарань та інших регіональних суб' єктах, що здійснюють підвищення кваліфікації.

Наведені у статті висновки не є безумовними, оскільки процес підвищення кваліфікації під дією як внутрішньосистемних, так і зовнішніх факторів буде підлягати певним змінам і тому вимагатиме постійного наукового розроблення та вдосконалення.

\section{Список використаних джерел}

1. Кагановська Т. С. Неперервна професійна освіта кадрів як один з етапів проходження державної служби в Україні. Науковий вісник Міжнародного гуманітарного університету. Сер.: Юриспруденція. 2013. № 6-1, том 1. С. 149-152.

2. Бутко М. П. Регіональні аспекти формування сучасного кадрового потенціалу в органах виконавчої влади та місцевого самоврядування. Свроатлантикінформ. 2005. № 5. С. 42-43.

3. Чайка Л. В. Проблеми підвищення кваліфікації міських голів. Вісник Національної академії державного управління. 2010. № 3. C. $70-77$.

4. Кісіль 3. Р. Стратегія реформування проходження державної служби в ОВС України. Науковий вісник Львівського державного університету внутрішніх справ. 2015. № 1. С. 201-210. 
5. Дука О. А. Вимоги до персоналу Державної кримінальновиконавчої служби України: професійний та морально-етичний аспекти. Юридична психологія та педагогіка. 2014. Вип. 1 (14). С. 79-91.

6. Ничкало Н. Г. Неперервна професійна освіта як філософська та педагогічна категорія. Неперервна професійна освіта: теорія $і$ практика. 2001. Вип. 1. С. 9-22.

7. Закон України про Державну кримінально-виконавчу службу України. Офіиійний вісник Украӥни. 2005. № 29. Ст. 1697.

8. Про затвердження Положення про організацію професійної підготовки осіб рядового і начальницького складу Державної кримінально-виконавчої служби України: наказ Міністерства юстиції України від 08.09.2015 р. № 1675/5. Офіиійний вісник України. 2015. № 76. Ст. 2546.

\section{Rebkalo M., Shumna L., Oliinyk V. FORMS OF PERSONNEL ADVANCED DEVELOPMENT OF CRIMINAL AND EXECUTIVE SERVICE OF UKRAINE: ADVANTAGES AND DISADVANTAGES}

Improving the professional skills of penitentiary personnel is a multifaceted process of obtaining additional knowledge to perform tasks and responsibilities within their professional activities. The article analyzes the main forms of personnel advanced training. The first is carried out in educational institutions of central executive bodies, local executive bodies (external form), and the second - in educational institutions of the State Penitentiary Service of Ukraine (internal form).

When clarifying the content of the external form, attention is paid to the model of its implementation. The first model is a holistic system of advanced training, which ensures the unity of the educational process and adequate educational technologies. The second is a variational model, which means working on a certain side of the profession that needs to be improved. The third model - involves using special diagnostics with subsequent monitoring of acquired knowledge. The article details the advantages and disadvantages of the external form of advanced training.

The internal form of advanced training provides the participation of educational institutions of the State Penitentiary Service in this process. The structure of bodies that provide advanced training within the State Penitentiary Service is revealed. Among its advantages is the possibility of involving experienced specialists of the penitentiary service in the training process, introduction of effective innovative technologies and motivation of service activity. The disadvantages of this form of education are also analyzed.

The article states the combination of external and internal forms helps to increase the level of professional knowledge and skills based on best practices used in various spheres of professional activity of society and allows to maximize the professions in bodies and penitentiary institutions.

Key words: State Criminal and Executive Service of Ukraine; penitentiary personnel; personnel advanced training system; external forms of advanced 
training; internal forms of advanced training; advantages and disadvantages of personnel advanced training.

\section{References}

1. Kahanovska, T. E. (2013), "Life long professional education as one of the stages of civil service in Ukraine", Scientific Bulletin of the International Humanities University, series: Jurisprudence, № 6-1, Vol 1, pp. 149-152.

2. Butko, M. P. (2005), "Regional aspects of formation of modern personnel potential in executive bodies and local self-government", EuroAtlanticinform, № 5, pp. 42-43.

3. Chaika, Л. V. (2010), "Problems of professional development of mayors", Bulletin of the National Academy of Public Administration, № 3, pp. 70-77.

4. Kisil, Z. R. (2015), "Strategy for reforming the civil service in the police of Ukraine", Scientific Bulletin of Lviv State University of Internal Affairs, №1, pp. 201-210.

5. Duka, O. A. (2014), "Requirements for the personnel of the State Penitentiary Service of Ukraine: professional and moral and ethical aspects", Legal Psychology and Pedagogy, Vol. 1 (14), pp.79-91.

6. Nichkalo, N. G. (2001), "Life long professional education as a philosophical and pedagogical category", Life long professional education: theory and practice, Vol. 1, pp. 9-22.

7. Ukraine (2005), On the State Penitentiary Service of Ukraine: Law of Ukraine, Verkhovna Rada of Ukraine, Kyiv.

8. Ukraine (2015), On the Statement of the Situation on the Organization of Advanced Training of Persons of Ordinary and Chief Structure of the State Criminal and Executive Service of Ukraine: Order, Ministry of Justice of Ukraine, Kyiv. 
УДК 342.9

DOI 10.32755/sjlaw.2020.02.063

Ткаченко О. Г., кандидат юридичних наук, заступник начальника кафедри тактико-спеціальної підготовки, Академія Державної пенітенціарної служби, м. Чернігів, Україна ORCID: 0000-0002-5640-0906;

Разумейко Н. С., кандидат педагогічних наук, начальник кафедри педагогіки та гуманітарних дисциплін,

Академія Державної пенітенціарної служби, м. Чернігів, Україна

ORCID: 0000-0003-0801-3490

\section{ПОНЯТТЯ ТА ХАРАКТЕРНІ РИСИ КОНФЛІКТУ ІНТЕРЕСІВ ПІД ЧАС ПРОХОДЖЕННЯ ДЕРЖАВНОЇ СЛУЖБИ В УКРАЇНI}

У статті проаналізовано поняття та характерні риси конфлікту інтересів, його вплив на систему державного управління; досліджено конфлікт інтересів на державній службі як різновид посадових зловживань. Розглянуто низку нормативних актів, які утворюють нормативно-правовий механізм врегулювання конфлікту інтересів на державній службі. Визначено недоліки наявного поняття конфлікту інтересів та вказано на шляхи усунення ичих недоліків.

Ключові слова: державна служба, конфлікт інтересів, врегулювання, корупція, антикорупційний механізм, посадова особа.

Постановка проблеми. Станом на сьогодні ні в кого не викликає сумнівів твердження про те, що особливо відповідальне місце в розбудові та функціонуванні України відведене державним службовцям, які, опираючись на конституційне закріплення їх прав та обов'язків, зобов'язані представляти державу, виконувати ії завдання та функції.

Оскільки державні службовці є реалізаторами державноуправлінської політики, а також уповноваженими особами, які ухвалюють відповідальні рішення щодо державного управління, вони є спеціальними суб'єктами, що мають змогу впливати не лише на поведінку окремого громадянина, групи суспільства, а й держави в цілому. Таким чином кожен державний службовець може створити деяку монополію у зв'язку з винятковою можливістю ухвалення рішення, що законодавчо віднесено до його компетенції як єдиний представник держави, що в свою 
чергу, може призвести до загрози використання ним свого службового становища у власних інтересах, зловживаючи наданою йому владою та наділеними повноваженнями 3 метою отримання неправомірної вигоди та корупції.

Серед великої кількості корупційних підстав важливе місце посідає конфлікт інтересів, що обгрунтовано обумовлене проблематичним історичним минулим, що відбувалось на території України, коли в громадян на підсвідомому рівні закріпилось правило вирішення проблем за допомогою так званих «своїх» людей, коли розподіл посад здійснювався за принципом «родинних зв'язків», а ухвалення важливих рішень відбувалось на користь інтересів окремих осіб. Усе це негативно впливало на ефективну діяльність державних службовців, підривало авторитет державного управління, знищувало довіру громадян до держави в цілому, а отже, є дуже актуальним питанням у сучасних умовах втілення в життя антикорупційної політики, побудови громадського суспільства та наближення України до європейських норм та стандартів.

Аналіз останніх досліджень і публікацій. На сьогодні питання поняття та характерні риси конфлікту інтересів під час проходження державної служби в Україні обговорюється досить активно, є предметом численних наукових досліджень та публікацій представників різних галузей науки. Фундаментальною та основоположною базою дослідження вказаної проблематики $є$ праці вітчизняних учених-юристів, які стосуються правового регулювання окремих аспектів діяльності, спрямованих на запобігання та врегулювання конфлікту інтересів в Україні, таких як: В. Александров, С. Алфьоров, В. Бевзенко, М. Бездольний, І. Дьомін, Д. Йосифович, Д. Заброда, В. Завгородній, Т. Коломоєць, В. Колпаков, А. Комзюк, О. Кузьменко, П. Лютіков, А. Манжула, М. Мельник, Р. Мельник, I. Нуруллаєв, С. Рогульський, С. Стеценко, В. Тильчик, О. Ткаченко, Р. Тучак, І. Яцків та ін.

Водночас в Україні відсутні праці вчених-юристів, присвячені комплексному дослідженню поняття та характерних рис конфлікту інтересів під час проходження державної служби в Україні. 
Мета статті полягає в тому, щоб на основі аналізу наукових джерел, вітчизняного та зарубіжного законодавства, узагальнення практики їх застосування охарактеризувати поняття та характерні риси конфлікту інтересів під час проходження державної служби в Україні, поглибити наукові знання та виявити проблеми правового регулювання й запропонувати науково обгрунтовані пропозиції щодо вдосконалення поняття конфлікту інтересів.

Виклад основного матеріалу. Державна служба є особливим владно-правовим інститутом, що здійснює функції державного управління щодо підготовки та виконання управлінських рішень, саме за допомогою яких і відбувається реалізація державної політики.

Як складний та специфічний вид управлінської діяльності державна служба висуває специфічні вимоги до майбутніх державних службовців залежно від їх посад, на яку вони претендують, та характеру і змісту роботи, яку вони будуть виконувати. Законодавство передбачає досить широкий перелік професійних, організаційних, морально-етичних, культурних якостей, норм та принципів поведінки, саме 3 яких і має складатись образ державного службовця.

Конституція та закони України як для посадових, так і для службових осіб органів державної влади та органів місцевого самоврядування чітко закріпили правила етичної поведінки, в тому числі й низку обмежень щодо їх позаслужбової діяльності. Такі обмеження звичайно $є$ конституційно обгрунтованими, оскільки певні особливості діяльності цих осіб об'єктивно можуть, а іноді дійсно створюють ситуацію, яка несумісна 3 належним виконанням ними службових обов'язків через виникнення конфлікту інтересів [1, с. 57].

Слушно звернув увагу О. Токар-Остапенко в своїй аналітичний доповіді «Врегулювання конфлікту інтересів на державній службі: можливості застосування європейського досвіду в Україні» - «конфлікти інтересів як специфічний вид соціального процесу виникає і виявляється в різноманітних галузях суспільної діяльності, і звичайно також у галузі державного управління, оскільки в ході проходження публічної служби державний 
службовець зустрічається з великою кількістю різних конфліктних ситуацій» [1, с. 57].

Підстав зростаючої уваги до врегулювання конфлікту інтересів під час проходження державної служби в Україні багато, серед основних можна виділити такі: зростання рівня вимог суспільства до органів державної влади; актуалізація потреби в подальшому проєвропейському напряму щодо державних службовців (розроблення та втілення в життя результативної системи публічного управління, яке б не лише відповідало стандартам демократичної правової держави із соціально-орієнтованою ринковою економікою, а й нормам міжнародного права); втілення догм публічного служіння суспільству та державі (бути готовим та мати здатність ототожнювати себе на службі «не володарями», а слугами та виконавцями важливих суспільних та державних інтересів, а отже, вони зобов' язані підпорядкувати їм особисті приватні інтереси), використовувати лише етичні норми поведінки під час реалізації службових повноважень тощо [2, с. 967-971].

Перш за все необхідно дослідити загальне визначення поняття «конфлікт» та з'ясувати зміст терміна «конфлікт інтересів», оскільки без розуміння загального неможливо розкрити спеціальне.

У великому тлумачному словнику сьогочасної української мови термін «конфлікт» (лат. conflictus) згідно 3 перекладом має значення «зіткнення» - це протидія, боротьба, суперечність, зіткнення особистостей, сил, інтересів, поглядів через несумісність, позицій, протистояння, протилежність; певний процес та розвиток протидії; певна система відносин залежно від різних видів суб'єктів - учасників конфлікту та залежно від розбіжності інтересу, цінностей, різного виду діяльності [3, с. 312].

$\mathrm{У}$ «Методичних рекомендаціях з питань запобігання та врегулювання конфлікту інтересів», закріплених у рішенні Національного агентства з питань запобігання корупції від 29 вересня 2017 року № 839, надано інше визначення, де конфлікт інтересів розуміється як суперечність між публічно-правовим обов'язком і приватним інтересом державного службовця, в разі настання якого іiі приватний інтерес, що безпосередньо випливає 3 його положення як приватної особи, здатне протипра- 
вним чином вплинути на виконання ним її офіційного обов'язку або функції [4].

Таким чином, ми дійшли до логічного рішення, що конфлікт інтересів - це становище, в разі настання якого державний службовець під час виконання своїх обов'язків має приватні інтереси чи особисту зацікавленість, яка хоч і не обов'язково призведе до ухвалення протиправного рішення або здійснення неправомірних діянь, але гіпотетично здатне до цього призвести.

Ми вважаємо, що запропонована дефініція поняття «конфлікт інтересів» у зазначених «Методичних рекомендаціях» потребує доопрацювання.

Оскільки першим недоліком цього визначення варто вважати те, що під час розкриття поняття «конфлікт» воно прирівняне до самого етимологічного значення слова «конфлікт», що не дозволяє розкрити його сутність.

Також закріплені в Законі України «Про запобігання корупції» службові та представницькі повноваження державного службовця, як складова двох елементів конфлікту інтересів, обмежується тільки його публічно-правовими обов'язками.

Аргументуючи цей погляд, варто було б звернути увагу на думку Г. Ткач, яка у своїх наукових роботах та особливо в статті «Поняття владного повноваження» зазначала, що владні повноваження можуть бути розглянуті як забезпечена законодавством вимога уповноважених суб'єктів до їх належної поведінки та дій, направлених на реалізацію прав громадян та юридичних осіб [5].

Автор обгрунтовано стверджує, що владні повноваження це веління (наказ, вимога, команда), звернене до адресата публічного правовідношення [5]. Саме тому ми вважаємо є помилкою ототожнювати службові та представницькі повноваження осіб з їх публічно-правовими обов'язками.

I на завершення хотілося б звернути увагу, що автор «Методичної рекомендації» обмежує в зазначеному визначенні перелік суб'єктів, у яких можливо виникне конфлікт інтересів та які закріплені в ст. 3 Закону України «Про запобігання корупціï» [6], тільки державними службовцями, залишивши без уваги: а) членів громадських рад, що утворені при державних органах та беруть участь у підготовці рішень із кадрових питань, 
підготовці, моніторингу, оцінці виконання антикорупційних програм; б) посадових осіб органів місцевого самоврядування; в) осіб, які не є державними службовцями, посадовими особами місцевого самоврядування, але надають публічні послуги; г) посадових осіб інших юридичних осіб публічного права, створених органами місцевого самоврядування.

Також під час розгляду цього питання необхідно звернути увагу і на розвиток поняття конфлікту інтересів під час проходження державної служби. На території нашої держави сам термін «конфлікт інтересів» вперше закріпили Загальні правила поведінки державного службовця від 04.08.2010 № 214. (Наказ втратив чинність на підставі Наказу Національного агентства України з питань державної служби № 158 від 05.08.2016 ). Згідно із положенням цього документа державний службовець повинен був заявити про наявний чи відсутній у нього конфлікт інтересів [1, с. 57].

Що саме цікаво вже тоді в «Загальних правилах» йшлося не лише про реальний, уже наявний конфлікт інтересів, але й про уявний (потенційний) конфлікт інтересів, іншими словами про випадок, який створював обгрунтовану підозру про можливість упереджених дій державної посадової особи.

Необхідно звернути увагу, що на відміну від старого Закону України «Про засади запобігання та протидії корупції» (втратив чинність на підставі Закону № 1700-VII від 14.10.2014), який закріпив єдине визначення - конфлікт інтересів, чинний Закон України «Про запобігання корупції» виділив два його види: потенційний конфлікт інтересів, а саме - наявність в особи приватного інтересу у сфері, в якій вона виконує свої службові чи представницькі повноваження, що може вплинути на об'єктивність чи неупередженість ухвалення нею рішень, або на вчинення чи невчинення дій під час виконання зазначених повноважень (абз. 9 ч. 1 ст. 1); реальний конфлікт інтересів, а саме суперечність між приватним інтересом особи та ії службовими чи представницькими повноваженнями, що впливає на об'єктивність або неупередженість ухвалення рішень, або на вчинення чи невчинення дій під час виконання зазначених повноважень (абз. 13 ч.1 ст. 1) [6]. 
Хотілося $б$ акцентувати увагу на те, що конфлікт інтересів під час проходження державної служби в Україні існує навіть тоді, коли він не має яких-небудь неетичних чи неправомірних дій. Сам конфлікт інтересів, який виник під час виконання державним службовцем своїх обов'язків, може виробити розуміння «бруду», що звичайно обов'язково призведе до недовіри громадян державним службовцям.

Проаналізувавши нормативні акти, ми хотіли б виділити основні характеристики конфлікту інтересів, а саме: суперечність між особистим інтересом державного службовця та інтересами держави; загроза об'єктивності державного службовця під час реалізації ним посадових обов'язків; можливість завдання шкоди законним інтересам держави.

Незважаючи на те, що теорія права термін «конфлікт інтересів» чітко визначає, під час практичної діяльності його досить тяжко охарактеризувати, оскільки не завжди чітко визначені межі між державними та особистими інтересами.

Тому прослідкувати ці межі досить важко, і отже, як наслідок, у нормативних актах різних країн стосовно природи та змісту конфліктів інтересів існує суттєва різниця.

Ситуація «конфлікту інтересів» містить також і моральну складову, оскільки на неї істотно впливає рівень морального розвитку державного службовця, від їх здатності самостійно вирішувати певні моральні дилеми. Проблемні моральні рішення державних службовців мусять бути чітко закріплені в нормативно-правових актах їх діяльності, комплексом заходів щодо запобігання подібних ситуацій, їх виконання, недопущення та обов'язково мінімізації шкідливих для особистості, суспільства і держави наслідків.

На жаль, ми повинні констатувати факт, що на сьогодні конфлікт інтересів знаходить свій вияв через такі нові вирази, як фаворитизм, кронізм та непотизм, які в свою чергу створюють безмежне коло варіантів отримання неправомірної вигоди, ці терміни допомагають нам більше збагнути, як на сьогодні $є$ корумповане наше суспільство, в якому вже давно знищені такі поняття, як професіоналізм, компетентність та відповідальність [7, c. 103-106]. 
Ми вважаємо, що поширення цих явищ зумовлює виникнення негативних тенденцій, таких як: поширення політики непрофесіоналізму, спадкової аристократії замість принципів меритократії; звільнення професійних співробітників 3 одночасним заміщенням особами близького оточення; широке розповсюдження та розквіт поняття «кумівство», що призводить до ухвалення негативного, неправильного управлінського рішення та створює нестабільні організаційні структури; втрата професійної компетенції, здібностей кадрового резерву; руйнування внутрішньої кон'юктури командної роботи; соціальне відчуження, відчуття безглуздості в організації; істотно зменшиться ефективність діяльності підприємств, установ та організацій, що негативно вплине на економічні показники; відсутня чи обмежена конкуренція серед персоналу, що знищує принцип компетентності та неупередженої кадрової роботи; укорінення династичних родинних стосунків як в урядовому, так і в приватному секторі, що призведе до ухвалення необ'єктивних рішень і, як результат, розвиток кланових-олігархічних стосунків.

Конфлікт інтересів є повсякчасно небезпечним, про що і говорить антикорупційне законодавство, оскільки в державного службовця можливо з'явиться бажання використати свої службові повноваження під час вирішення питання, а отже, виникає можливість отримати за це матеріальну чи іншу винагороду.

Також саме поняття «конфлікту інтересів» є оціночне, оскільки майже неможливо точно сформулювати перелік усіх приватних інтересів державного службовця та закріпити всі життєві ситуації, в разі настання яких виникне конфлікт з інтересом служби.

Щодо основних каталізаторів появи конфлікту інтересів державних службовців, то до основних можна віднести такі: невисокий моральний рівень конкретного державного службовця; недосконалість системи звітності, контролю та аудиту діяльності; відсутність норм і правил вирішення виниклого конфлікту інтересів; наявність у службовій діяльності (посадових функціях) галузей, що передбачають ухвалення рішень на підставі суб' єктивних оцінок [8, с. 237].

Отже, однією з головних передумов у разі появи конфлікту інтересів під час проходження державної служби вчені- 
адміністративісти наводять недосконале (або й взагалі відсутне) відповідне законодавство щодо системи контролю за його виконанням через специфічні контролюючі органи.

На сьогодні ні в кого не виникає сумнівів, що брак уваги i невирішення питань конфлікту інтересів призводить до корупційної складової. Беручи до уваги гігантський обсяг правовідносин, які виникають між громадянами та державними службовцями, та наявний у них фінансовий інтерес, який, власне і перебуває в центральній увазі, неврегульований конфлікт інтересів може бути великим вантажем для економіки держави. Так це може підірвати конкуренцію, зумовити розкрадання під час розподілу державних ресурсів або їх зайве витрачання та спричинити лиху славу, що неминуче дасть привід до зневіри громадян стосовно державних службовців.

Ми вважаємо, що з метою уникнення конфлікту інтересів під час проходження державної служби в Україні слід змінити підхід до певних обставин, здійснювати пошук найбільш оптимального варіанта під час регулювання роботи певного державного службовця 3 метою не дозволити вплинути на приватний інтерес державного службовця щодо обгрунтованого і добросовісного вчинення дій та ухвалення ним рішень.

Висновки. Провівши дослідження змісту та соціальноправової природи поняття й характерних рис конфлікту інтересів на державній службі в Україні, ми дійшли висновку, що в теорії права термін «конфлікт інтересів» не має чіткого визначення. На законодавчому рівні закріплені два його види: потенційний та реальний конфлікт інтересів, саме тому ми пропонуємо авторське визначення цього поняття. Конфлікт інтересів це становище, в разі настання якого державний службовець під час виконання своїх обов'язків має приватні інтереси чи особисту зацікавленість, яка хоч і не обов'язково призведе до ухвалення протиправного рішення або здійснення неправомірних діянь, але гіпотетично здатне до цього призвести.

Важливим етапом може стати створення ефективного механізму запобігання виникненню конфлікту інтересів у контексті формування нової Антикорупційної стратегії та розроблення 
відповідних методичних рекомендацій щодо питань розмежування понять «непотизм», «кронізм» та «фаворитизм».

Ми вважаємо, що запобігання та врегулювання конфлікту інтересів під час проходження державної служби в Україні повинно також регулюватися «Кодексом честі» та «Правилами етичної поведінки державного службовця», яких на сьогодні просто не існує. Вони мали б об'єднати фундаментальні засади, закріпили б обов'язок виконувати певні заборони та обмеження, що стосуються державних службовців, які обіймають відповідальні посади та мають особливо відповідальне становище.

\section{Список використаних джерел}

1. Токар-Остапенко О. В. Врегулювання конфлікту інтересів на державній службі: можливості застосування європейського досвіду в Україні. Київ: НІСД, 2018. 57 с. URL: http://www.niss.gov.ua/content/ articles/files/derhs_sluhs-06511.pdf (дата звернення: 10.06.2020).

2. Борко Т. М. Засоби врегулювання конфлікту інтересів державних службовців. Молодий вчений. 2018. № 11 (2). С. 967-971. URL: http://nbuv.gov.ua/UJRN/ (дата звернення: 10.06.2020).

3. Великий тлумачний словник сучасної української мови / укл. і гол. ред. В.Т. Бусел. Київ; Ірпінь: Перун, 2015. 312 с.

4. Про затвердження Методичних рекомендацій щодо запобігання та врегулювання конфлікту інтересів: рішення Національного агентства 3 питань запобігання корупції від 29 вересня 2017 року № 839. URL: https://zakon.rada.gov.ua/rada/show/v0839884-17 (дата звернення: 10.06.2020).

5. Ткач Г. Поняття владного повноваження. URL: http://radnuk.info/pidrychnuku/admin-pravo/495-butyak/21371-2012-0618-20-58-49.html (дата звернення: 10.06.2020).

6. Про запобігання корупції: Закон України від 14 жовтня 2014 року № 1700-VII. URL: http://zakon2.rada.gov.ua/laws/show/1700-18 (дата звернення: 10.06.2020).

7. Діденко І. Неопотизм, фаворитизм та кронізм як причини виникнення конфлікту інтересів. Підприємництво, господарство і право. 2017. № 8. C. 103-106. URL: http://nbuv.gov.ua (дата звернення: 10.06.2020).

8. Запобігання й протидія проявам корупції як елемент модернізації системи державної служби / Івано-Франківський центр науки, інновацій та інформатизації. Івано-Франківськ, 2017. 237 с. 


\section{Tkachenko O., Razumeiko N. CONCEPTS AND CHARACTERISTICS OF CONFLICT OF INTEREST DURING CIVIL SERVICE IN UKRAINE}

Today no one doubts that the special responsibility in the development and functioning of Ukraine is given to civil servants, who, based on the constitutional enshrinement of their rights and responsibilities, are obliged to represent the state and perform its tasks and functions.

Among the large number of corruption grounds, the conflict of interests takes an important place, which is reasonably due to the problematic historical past that took place in Ukraine, when citizens subconsciously established the rule of solving problems with the help of so-called "their" people, when the distribution of positions was carried out on the principle of "family ties", and important decisions were made in favor of the interests of individuals. All this had a very negative impact on the effective activities of civil servants, undermined the authority of public administration, destroyed the trust of citizens in the state as a whole, and therefore is an extremely important issue in the current implementation of anticorruption policy, building civil society and bringing Ukraine closer to European norms and standards.

The civil service is a special institution of power and law, which performs the functions of public administration in the preparation and implementation of management decisions through which the implementation of public policy.

As a complex and specific type of managerial activity, the civil service makes specific requirements for future civil servants depending on their positions for which they apply and the nature and content of the work they will perform. The legislation provides a fairly wide list of professional, organizational, moral and ethical, cultural qualities, norms and principles of conduct, which should be the image of a civil servant.

Key words: civil service, conflict of interest, regulation, corruption, anticorruption mechanism, official.

\section{References}

1. Tokar-Ostapenko, O. V. (2018), Settlement of conflict of interest in the civil service: the possibility of applying the European experience in Ukraine, NISS, Kyiv, available at: http:/www.niss.gov.ua/content/articles/ files/derhs_sluhs-06511.pdf (accessed 10 June 2020).

2. Borko, T. (2018), "Means of resolving conflicts of interest of civil servants", A young scientist, Vol. 11 (2), pp. 967-971, available at: http://nbuv.gov.ua/UJRN/ (accessed 10 June 2020).

3. Large explanatory dictionary of the modern Ukrainian language (2015), Perun, Kiev; Irpen.

4. On approval of the Guidelines for the prevention and settlement of conflicts of interest: Decision of the National Agency for the Prevention of 
Corruption dated September 29, 2017 № 839, available at: https://zakon.rada.gov.ua/rada/show/v0839884-17 (accessed 10 June 2020).

5. Weaver, G. (2018), The concept of power, available at: http://radnuk.info/pidrychnuku/admin-pravo/495-butyak/21371-2012-0618-20-58-49.html (accessed 10 June 2020).

6. Ukraine (2014), On Prevention of Corruption: Law of Ukraine, № 1700-VII, available at: http://zakon2.rada.gov.ua/laws/show/1700-18 (accessed 10 June 2020).

7. Didenko, I. (2017), "Neopotism, favoritism and cronism as causes of conflict of interest": Entrepreneurship, Economy and Law, Vol. 8, pp. 103-106, available at: http://nbuv.gov.ua (accessed 10 June 2020).

8. Prevention and counteraction to corruption as an element of modernization of the civil service system (2017), Innovation and Informatization, Ivano-Frankivsk. 


\section{КРИМІНАЛЬНЕ ПРАВО, КРИМІНОЛОГІЯ, КРИМІНАЛЬНО- ВИКОНАВЧЕ ПРАВО}

УДК 343.851

DOI 10.32755/sjlaw.2020.02.075

Афанасенко А. С.,

слухач II курсу 461навчальної групи, Академія Державної пенітенціарної служби, м. Чернігів, Україна;

Кондратов Д. Ю., кандидат юридичних наук, доцент, доцент кафедри кримінального права і кримінології, Харківський національний університет внутрішніх справ,

м. Харків, Україна ORCID: 0000-0001-5426-4878;

Боднар I. B., кандидат юридичних наук, начальник кафедри тактико-спеціальної підготовки, Академія Державної пенітенціарної служби, м. Чернігів, Україна ORCID: 0000-0002-7814-9476

\section{ПЕРЕКРИТТЯ КАНАЛІВ НАДХОДЖЕННЯ ДО ЗАСУ ДЖЕНИХ ЗАБОРОНЕНИХ ПРЕДМЕТІВ ЯК ПРОТИДІЯ ПЕНІТЕНЦІАРНІЙ ЗЛОЧИННОСТІ}

У статті розглянуто процес перекриття каналів надходження до засуджених заборонених предметів як основної протидії злочинності, наведено заходи, які проводяться з метою запобігання вчиненню злочинам в установах виконання покарань. Визначено роль окремих служб установ виконання покарань у забезпеченні правопорядку на територіях установ виконання покарань. Встановлено, щзо законодавство України потребує новітніх змін иляхом доповнення новими нормами, які були б орієнтовані саме на безпеку персоналу в УВП з урахуванням тенденцій розвитку нашої держави та кримінально-виконавчого законодавства.

Ключові слова: заборонені предмети, перекриття, канали надходження, установи виконання покарань, виявлення.

Постановка проблеми. Аналіз криміногенної ситуації в установах виконання покарань (УВП) Державної кримінальновиконавчої служби України (ДКВС України) останніми роками характеризується неоднозначними тенденціями. Незважаючи на 
загальне зниження кількості засуджених, якісний склад осіб, які відбувають покарання, постійно погіршується.

В Україні станом на 1 січня 2019 року згідно $з$ даними Мiністерства юстиції України перебувало 55078 осіб в 148 установах кримінально-виконавчої системи України, які контролюються українською владою, тобто без установ Криму та окупованої частини Донецької та Луганської областей. Рік тому їх кількість становила 57100 осіб, що на 2022 особи більше.

Криміногенний склад засуджених до позбавлення волі на 1 січня 2019 року: 5514 осіб засуджені на строк понад 10 років; 6967 осіб - за умисне вбивство; 2939 осіб - за нанесення умисного тяжкого тілесного ушкодження; 7719 осіб - за розбій, грабіж та вимагання; 12140 осіб - за крадіжку; 693 особи - за згвалтування; 14 осіб - злочини проти основ національної безпеки [1].

Проникнення заборонених предметів до УВП справляє негативний вплив на оперативну обстановку, а рівень організації боротьби з ними не адекватний поставленим вимогам. Вивчення проблем, пов'язаних із запобіганням проникненню заборонених предметів до УВП, визначення закономірностей вчинення цього виду правопорушень співробітниками та іншими особами, виявлення причин і умов, які сприяють вчиненню діянь кримінального характеру з їх боку, розроблення і здійснення ефективних заходів щодо їх запобігання потребують проведення комплексних наукових досліджень.

Аналіз останніх досліджень і публікацій. Теоретичною базою дослідження проблем проникнення заборонених предметів на території установ виконання покарань стали праці фахівців 3 кримінально-виконавчого права, кримінології, кримінального права, зокрема: І. Г. Богатирьова, Є. М. Бодюла, І.В. Боднара, В. В. Василевича, А. Д. Глоточкіна, О. М. Гуміна, О. І. Гурова, С. І. Дементьєва, Т. А. Денисової, Р. А. Джансараєвої, О. М. Джужи, В. М. Дрьоміна, А. П. Закалюка, А. Ф. Зелинського, О. Г. Колба, О. М. Литвака, О. М. Литвинова, В. В. Лунєєва, О. А. Мартиненка, Г. О. Радова, О. П. Северова, В. П. Севастьянова, I. С. Сергеєва, О. О. Титаренка, О.Г. Ткаченко, В. М. Трубникова, С. В. Царюка, С. Я. Фаренюка, Ю. В. Шинкарьова та ін. 
Метою статті $є$ комплексний аналіз каналів надходження до засуджених заборонених предметів, визначення шляхів недопущення надходження заборонених предметів на території установ виконання покарань.

Виклад основного матеріалу. Забезпечення режиму, ізоляції і безпеки осіб під час відбування покарань $є$ основою діяльності установ виконання покарань Державної кримінальновиконавчої служби України, які здійснюють свою діяльність у складній соціально-політичній та економічній обстановці, що складається останніми десятиліттями в Україні. Як наслідок, спроби з боку окремих осіб поліпшити своє матеріальне становище за рахунок купівлі-продажу заборонених предметів у місцях відбування покарання засудженими - не рідкість.

Тенденції проникнення заборонених предметів на територію УВП є суспільно небезпечними в силу того, що заборонені предмети сприяють вчиненню такого злочинного діяння засудженими, як втеча, i сприяють іншим протиправним діям з боку засуджених у місцях відбування покарання (масові заворушення, захоплення заручників, групова непокора, напад на співробітників та ін.).

УВП є об'єктами підвищеного кримінального ризику. Концентрація злочинців в одній установі сама по собі не створює сприятливих умов для їх декриміналізації та ресоціалізації. Наявність у засуджених заборонених предметів ускладнює криміногенну та оперативну обстановку в УВП, прискорює реалізацію ними злочинних задумів, у тому числі і втеч. Усе це виявляе суспільну небезпеку проникнення заборонених предметів на території УВП.

3 метою забезпечення правопорядку в органах, установах виконання покарань та слідчих ізоляторах ДКВС України, надійного перекриття шляхів надходження до зон, що охороняються, заборонених предметів, виробів і речовин, зберігання і використання яких засудженими заборонено, а також запобігання їх виготовлення засудженими та ув'язненими проводяться спеціальні операції «Заслон» та «Щит».

Під час здійснення заходів 3 перекриття шляхів надходження до зон, що охороняються, заборонених предметів, виробів і 
речовин, зберігання і використання яких засудженими заборонено, при спробі доставки до зон, що охороняються, найбільшу кількість заборонених предметів вилучено в установах: Південно-Східного міжрегіонального управління 3 питань виконання кримінальних покарань та пробації Міністерства юстиції (далі МРУ) (311 г наркотичних засобів, 30 л спиртовмісної речовини, гроші у сумі 2469 грн та 25 євро, 57 мобільних телефонів) та Західного МРУ (36 л спиртовмісної речовини, гроші у сумі 1006 грн, 207 мобільних телефонів). Найменшу кількість заборонених предметів вилучено в установах Центрально-Західного МРУ (13 л спиртовмісної речовини, гроші у сумі 280 грн та 11 мобільних телефонів).

Основними каналами доставки заборонених предметів є посилки та передачі [2].

Можна стверджувати, що наявність у засуджених заборонених предметів $є$ причиною вчинення більшості злочинів у місцях позбавлення волі.

Згідно з інформацією, що надійшла 3 міжрегіональних управлінь 3 питань виконання кримінальних покарань та пробації Міністерства юстиції України до Адміністрації ДКВС України, протягом проведення спеціальної операції засудженими (ув'язненими) допущено 672 порушення встановленого режиму тримання, в тому числі: вживання спиртних напоїв - 11; невиконання законних вимог адміністрації - 75; порушення локалізації - 46; виготовлення та зберігання заборонених предметів - 274 .

Відкрито 4 кримінальні провадження проти засуджених за ст.ст. 309 ч. 1, 391 Кримінального кодексу України [3].

Аналізуючи відомі випадки спроб доставки заборонених предметів в УВП, можна виділити декілька категорій осіб, які причетні до цього процесу, а саме:

1. Близькі родичі засуджених, яким кримінально-виконавчим законодавством надано право на тривалі побачення. Часто родичі, які прибувають на тривалі побачення, намагаються пронести заборонені предмети, приховуючи їх різними способами.

2. Родичі засуджених та інші особи, які намагаються передати заборонені предмети та речовини в передачах, посилках та бандеролях. 3 цією метою використовують різноманітні спосо- 
би приховування: від примітивних - до таких, що потребують ретельної підготовки. Наприклад, виготовлення фабричної упаковки та маркування, застосування особливих хитрощів маскування тощо.

3. Персонал УВП. Засуджені різними способами намагаються втягти у недозволені зв'язки працівників УВП. Водночас непоодинокими є випадки, коли працівники добровільно 3 корисливих мотивів доставляють засудженим заборонені предмети.

4. Особи, що перекидають заборонені предмети через огорожі УВП. Як правило, найбільша кількість таких осіб складається з родичів, друзів або осіб, які раніше відбували покарання.

5. Особи, які використовують транспортні засоби для доставки заборонених предметів на територію УВП. У таких випадках цими особами $\epsilon$ водії, які постачають сировину для виробництва, сховавши заборонені предмети у вузлах, або серед самої сировини (деревини, металу тощо).

6. Інші особи, що мають доступ на територію установ, інколи представники релігійних громад, соціальні працівники, що відвідують установу [4, с. 569].

Потрапляння на територію УВП навіть одного із заборонених предметів викликає неабияку небезпеку. Адже, наприклад, колючо-ріжучі предмети, такі як: ножі та шила - можуть стати знаряддям нападу як на інших засуджених, так і на персонал установи. Спортивний інвентар може 3 легкістю перетворитися в знаряддя нападу.

Не варто забувати, що неабияку суспільну небезпеку в собі несуть алкогольні напої, наркотичні, психотропні речовини та дріжджі, адже більшість насильницьких злочинів вчиняється саме в стані алкогольного чи наркотичного сп'яніння.

За допомогою мобільних телефонів засуджені можуть здійснювати різні шахрайства, організовувати скоєння втеч та порушувати ізоляцію засуджених як принцип виправлення.

Гроші та вироби з дорогоцінних металів можуть прискорювати реалізацію злочинних задумів. Наприклад, як засіб підкупу співробітників та інших осіб з метою вчинення ними незаконних дій. 
Гральні карти в установах виконання покарань можуть призвести до серйозних наслідків, адже вони стають підставою для конфліктів між засудженими, що може призвести до правопорушень [5, с. 75$]$.

Проникнення до засуджених заборонених предметів, виробів і речовин є можливим лише за наявності серед засуджених осіб, що виношують наміри отримання спиртних напоїв, наркотичних речовин, засобів мобільного зв'язку та при існуванні створених засудженими неконтрольованих персоналом каналів і зв'язків з родичами, друзями та іншими особами, які перебувають поза місцями позбавлення волі. За наявності співробітників, які вступили у незаконні стосунки із засудженими, їхніми родичами або іншими особами 3 метою отримання неправомірної вигоди або досягненні інших корисливих цілей.

Низький рівень організації роботи щодо запобігання проникнення заборонених предметів, виробів і речовин на територію установи виконання покарань, виявлення осіб, що мають наміри налагодити канал надходження заборонених предметів, а також несвоєчасне виявлення таких каналів спричиняє появу у засуджених заборонених предметів.

Як свідчить практика, інколи ефективну та успішну роботу УВП можуть зводити нанівець вчинені правопорушення та злочини, серед яких є ті, що пов'язані з проникненням заборонених предметів і їх обігом. Тому з метою підтримання належного правопорядку та законності в місцях позбавлення волі у практичній діяльності УВП уживаються заходи, спрямовані на перекриття каналів надходження заборонених предметів, їх своєчасне виявлення та вилучення. Основними напрямками такої діяльності є: оперативно-розшукова робота; виховна та соціально-психологічна робота 3 персоналом ДКВС України; проведення спеціальних операцій, режимних заходів, оглядів та обшуків, особистих обшуків засуджених; забезпечення надійної охорони об'єктів, територій та приміщень УВП, здійснення модернізації інженерно-технічних засобів.

Вищенаведений комплекс заходів необхідно постійно проводити, вдосконалювати та запроваджувати здобутки інших держав у становленні ДКВС України. 
Важливу роль у перекритті каналів надходження до засуджених заборонених предметів відіграє належне проведення доглядів передач, посилок і бандеролей, що надходять на ім'я засуджених. Також проведення особистих оглядів засуджених, що прибувають в УВП, та осіб, які прибувають на тривалі побачення із засудженими.

Слід звернути увагу на проведення спеціальної операції в УВП, а саме на спеціальну операцію під умовною назвою «Заслон».

Спеціальна операція «Заслон» проводиться 3 метою надійного перекриття каналів надходження в зони, що охороняються, заборонених до використання речей і предметів, а також запобіганню їх виготовленню засудженими. Спеціальна операція передбачає здійснення заходів щодо ліквідації каналів надходження заборонених предметів, виробів та речовин, їх виявлення та вилучення, проведення оглядів об'єктів та обшуків засуджених на території УВП, особистих оглядів осіб, що заходять на територію установи виконання покарань.

Отже, якісне та своєчасне перекриття каналів надходження заборонених предметів на територію установи виконання покарань $\epsilon$ необхідною умовою для забезпечення належного порядку виконання та відбування кримінальних покарань. Адже від рівня обігу установі заборонених предметів безпосередньо залежить стан криміногенної обстановки.

Висновки. Висвітлений у статті матеріал свідчить про те, що проблема проникнення на території установ виконання покарань заборонених предметів є актуальною та потребує подальшого розгляду з покращенням методів і заходів з недопущення здійснення ймовірних злочинних намірів як з боку засуджених, так і 3 боку інших осіб.

Для покращення протидії 3 перекриття каналів надходження до засуджених заборонених предметів потрібно:

1) використовувати новітні технології в галузі забезпечення охорони периметрів установ виконання покарань;

2) внести зміни до чинного законодавства щодо збільшення відповідальності за передачу заборонених предметів на території установ виконання покарань; 


\section{3) проводити 3 персоналом Державної кримінально-} виконавчої служби профілактичну роботу з метою наголошення на недопущення налагодження неслужбових зв'язків із засудженими та іншими особами.

\section{Список використаних джерел}

1. Кримінально-виконавча система України в 2018 році. Статистичний огляд. URL: http://ukrprison.org.ua/news/1548745687 (дата звернення: 30.06.2020).

2. Результати проведення спеціальних операцій «Заслон» та «Щит». URL: https://www.kvs.gov.ua/peniten/control/chv/uk/publish/article/896476; jsessionid=8CEC991EDB525B5B434692E8DE51ED79 (дата звернення: 30.06.2020).

3. Результати проведення спеціальної операції «Щит». URL: https://www.kvs.gov.ua/peniten/control/cry/uk/publish/article/900716;jsess ionid=DC60D6E8977FCC10150A4740A1F09774 (дата звернення: 20.09.2020).

4. Кримінологічні засади запобігання злочинам в установах виконання покарань України (пенітенціарна кримінологія): посібник / за ред. О.М. Джужі. Київ: НАВС, 2013. 620 с.

5. Хохрин С. А. Правовые и организационные проблемы перекрытия каналов проникновения в пенитенциарные учреждения запрещенных предметов. Вестник Воронежского института МВД России. 2012. Вып. 3. С. 75-78.

\section{Afanasenko A., Kondratov D., Bodnar I. BLOCKING CHANNELS OF INCOMING PROHIBITED ITEMS TO CONVICTS, AS A COUNTERACTION OF PENITENTIONARY CRIME}

The process of blocking channels of incoming prohibited items to convicts, as the main counteraction to crime are considered in the article. Measures taken to prevent the commission of crimes in penal institutions are provided. The role of specific services of penal institutions in ensuring law and order on the territories of penal institutions is determined. It is established that the legislation of Ukraine needs the latest changes, by supplementing it with new norms, which would be focused on the safety of the personnel in the penitentiary system, taking into account the development trends of our state and criminal-executive legislation.

It is emphasized in the article that in order to ensure law and order in penal bodies, institutions and pre-trial detention centers of the State Criminal and Executive Service of Ukraine, reliable blocking of incoming to protected areas, prohibited items, products and substances, storage and use of which is prohibited, as well as preventing their manufacturing, convicts and prisoners undergo special operations "Barrier" and "Shield". 
The authors singled out the categories of persons who are most inclined to hand over prohibited items to convicts, namely: convicts' close relatives who have been granted the right to long-term visits by criminal-executive legislation; convicts' relatives and other persons who try to transfer prohibited items and substances in transmissions, parcels and packages; PI staff; relatives, friends or former servicemen who throw prohibited items over the fences of the penal institution; persons who use vehicles to deliver prohibited items to the territory of the penal institution; other persons who have access to the territory of such institutions.

The authors came to the conclusion that in order to improve the counteraction to the blocking of the channels of incoming prohibited items to convicts, it is necessary to: use the latest technologies in the field of protection of the perimeters of the penal institutions; amend existing legislation and improve preventive work in this area.

Key words: prohibited items, blocking, channels of incoming, penal institutions, detection.

\section{References}

1. The criminal justice system of Ukraine in 2018, Statistical review, available at: http://ukrprison.org.ua/news/1548745687.

2. Results of Special "Barrier" and "Shield" Operations, available at: https://www.kvs.gov.ua/peniten/control/chv/en/publish/article/896476; jsessionid = 8CEC991EDB525B5B434692E8DE51ED79.

3. The results of the special operation "Shield", available at: https://www.kvs.gov.ua/peniten/control/cry/en/publish/article/900716; jsessionid = DC60D6E8977FCC10150A4740A1F09774.

4. Criminological principles of crime prevention in penitentiary institutions in Ukraine (penitentiary criminology) (2013): manual / in Dzuzhi, O. M. (Ed.), NAVS, Kiev.

5. Khokhrin, S. A. (2012), "Legal and organizational problems of overlapping of channels of penetration into the penitentiary institutions of prohibited objects", Bulletin of the Voronezh Institute of the Ministry of Internal Affairs of Russia, Issue 3, pp. 75-78. 
УДК 343.9

DOI 10.32755/sjlaw.2020.02.084

Самофалов Л. П., кандидат юридичних наук, доцент, доцент кафедри теорії та історії держави і права, конституційного права, Академія Державної пенітенціарної служби, м. Чернігів, Україна ORCID: 0000-0001-7626-4270;

Самофалов О. Л., кандидат юридичних наук, доцент кафедри адміністративного, цивільного та господарського права і процесу, Академія Державної пенітенціарної служби, м. Чернігів, Україна

ORCID 0000-0001-9157-7435

\section{ПРОБЛЕМИ ПРАВОВОГО РЕГУЛЮВАННЯ БОРОТЬБИ 3 ТЕРОРИЗМОМ ТА ЗАПОБІГАННЯ ТЕРОРИСТИЧНИМ АКТАМ}

Стаття присвячена дослідженню проблемних питань правового регулювання боротьби з тероризмом та запобігання терористичним актам. Усебічно проаналізовано сучасний стан запобігання вчинення злочинів терористичними угрупованнями. Встановлено, коло суб' сктів антитерористичної діяльності, не передбачених чинним законодавством, та відповідні недоліки, які виникають під час боротьби з тероризмом.

Ключові слова: тероризм, терористичний акт, терористична операчія, злочини, суб'єкти, кримінальна відповідальність.

Постановка проблеми. На сучасному етапі основною, реальною та потенційною загрозою національній безпеці України, стабільності в суспільстві у сфері державної безпеки є тероризм. Протидія такого роду протиправній діяльності потребує вдосконалення наявного антитерористичного законодавства 3 метою його узгодження 3 міжнародними та внутрішньодержавними законодавчими актами

Аналіз останніх досліджень і публікацій. Питання правового регулювання діяльності збройних формувань у зоні проведення антитерористичних операцій були об'єктами досліджень таких науковців, як Ю. Абаджиєв, А. Данилевський, В. Смельянов, В. Ляшенко, С. Мохончук, М. Семикін, М. Сукмановська, А. Форос, В. Шамара, Л. Шестопалова та інші.

Метою статті $\epsilon$ висвітлення загальних проблем правового регулювання боротьби з тероризмом та запобігання терористичним актам. 
Виклад основного матеріалу. Одним із пріоритетних напрямів діяльності держави 3 організації ефективної боротьби 3 тероризмом $є$ створення та подальше вдосконалення законодавства у сфері протидії тероризму, яке б повною мірою враховувало сучасні загрози та створювало надійне підгрунтя для забезпеченням безпеки всіх осіб, які перебувають на території України [1].

Тероризм - суспільно небезпечна діяльність, яка полягає у свідомому, цілеспрямованому застосуванні насильства шляхом захоплення заручників, підпалів, убивств, тортур, залякування населення та органів влади або вчинення інших посягань на життя чи здоров'я ні в чому не винних людей або погрози вчинення злочинних дій з метою досягнення злочинних цілей [2].

Терористичний акт - це застосування зброї, вчинення вибуху, підпалу чи інших дій, які створювали небезпеку для життя чи здоров’я людини, або заподіяння значної майнової шкоди чи настання інших тяжких наслідків, якщо такі дії були вчинені 3 метою порушення громадської безпеки, залякування населення, провокації воєнного конфлікту, міжнародного ускладнення, або 3 метою впливу на ухвалення рішень чи вчинення або невчинення дій органами державної влади чи органами місцевого самоврядування, службовими особами цих органів, об’єднаннями громадян, юридичними особами, або привернення уваги громадськості до певних політичних, релігійних чи інших поглядів винного (терориста), а також погроза вчинення зазначених дій 3 тією самою метою [3].

Правову основу боротьби з тероризмом становлять Конституція України, Кримінальний кодекс України, закон України «Про боротьбу з тероризмом», інші закони України, Свропейська конвенція про боротьбу з тероризмом 1977 р., Міжнародна конвенція про боротьбу з бомбовим тероризмом 1997 р., Міжнародна конвенція про боротьбу з фінансуванням тероризму 1999 р., інші міжнародні договори України, згода на обов'язковість яких надана Верховною Радою України, укази Президента України, постанови та розпорядження Кабінету Міністрів України, а також інші нормативно-правові акти, що ухвалюються на виконання законів України. 
Законом України «Про боротьбу з тероризмом» встановлено, що головним суб'єктом у загальнодержавній системі протидії тероризму є Служба безпеки України.

Необхідно зауважити, що вказаний Закон не відносить до суб'єктів боротьби з терористичними виявами Національну гвардію України, хоча в Законі України «Про Національну гвардію України» визначена функція участі у заходах, пов'язаних із припиненням терористичної діяльності [4]. На сьогодні Національна гвардія України відіграє важливу роль у проведенні антитерористичних операцій, а також забезпечує захист більшості важливих державних об'єктів, у т. ч. від терористичних посягань. Очевидно, що норми зазначених законів мають бути приведені у відповідність, а Національна гвардія України включена до переліку суб'єктів боротьби з тероризмом.

Серед нормативно-правових актів, що регулюють відносини у сфері протидії тероризму, одне з чільних місць посідає Закон України «Про запобігання та протидію легалізації (відмиванню) доходів, одержаних злочинним шляхом, фінансуванню тероризму та фінансуванню розповсюдження зброї масового знищення» від 14 жовтня 2014 р. Цей Закон ухвалено з метою забезпечення захисту прав та законних інтересів громадян, суспільства i держави, забезпечення національної безпеки шляхом визначення правового механізму протидії легалізації (відмиванню) доходів, одержаних злочинним шляхом, фінансуванню тероризму та фінансуванню розповсюдження зброї масового знищення, а також формування загальнодержавної багатоджерельної аналітичної бази даних для надання правоохоронним органам України та іноземних держав можливості виявляти, перевіряти і розслідувати злочини, пов'язані з відмиванням коштів та іншими незаконними фінансовими операціями [5]. Законом передбачено умови та порядок «заморожування» активів міжнародних терористичних угруповань і осіб, пов'язаних із провадженням терористичної діяльності, а також конфіскації таких активів, що, на наш погляд, дозволяє віднести ці заходи до переліку найбільш ефективних засобів боротьби з міжнародним тероризмом.

Водночас положення зазначеного Закону потребують уточнення щодо можливості зупинення фінансових операцій органі- 
зацій, визнаних терористичними в Україні. Ця проблема виникла з огляду на трансформацію характеру терористичної загрози в Україні, а також у зв'язку із неврегульованістю відповідної процедури.

Разом 3 тим необхідно погодитись 3 думкою С. А. Трофимова, що закріплених у Законі заходів запобігання та припинення терористичних актів гіпотетично може бути недостатньо. Необхідно навести низку заходів запобігання та припинення терористичних актів, що обов'язково мають отримати своє закріплення у вітчизняному законодавстві.

По-перше, під час проведення антитерористичної операції, як правило, виникає необхідність у посиленні охорони громадського порядку, а також об'єктів, що підлягають державній охороні, забезпечують життєдіяльність населення й функціонування транспорту або ж мають особливу матеріальну, історичну, наукову, культурну чи іншу цінність.

По-друге, вбачається необхідним під час проведення антитерористичної операції ведення контролю телефонних переговорів та іншої інформації, що передається по різних каналах зв'язку з метою виявлення відомостей про обставини здійснення терористичного акту та осіб, що його підготували й вчинили, а також попередження здійснення інших терористичних актів. Такі заходи є доречними, оскільки терористи, які були оточені, можуть передавати інформацію своїм прибічникам, координувати діяльність або отримувати відповідні рекомендації щодо своєї поведінки.

По-третє, у районі проведення антитерористичної операції слід тимчасово призупиняти діяльність небезпечних виробництв, а також організацій, діяльність яких пов'язана із використанням вибухових, радіоактивних, хімічно й біологічно небезпечних речовин, оскільки існує вірогідність можливого захоплення таких об’єктів терористами або ж їх використання для спричинення максимально тяжкої шкоди.

По-четверте, з урахуванням розвитку телекомунікаційної сфери під час усунення терористичної загрози з'являється потреба в призупиненні надання послуг зв'язку юридичним і фізичним особам або обмеженні використання мереж зв'язку й за- 
собів зв’язку. Така необхідність пояснюється розповсюдженим використанням як одного з елементів детонатора для вибухового пристрою мобільних телефонів, а також можливість використання телекомунікаційних засобів для узгодження злочинної поведінки.

По-п'яте, в окремих випадках постає необхідність тимчасового відселення фізичних осіб, що мешкають у межах території, на якій введений правовий режим району проведення антитерористичної операції, у безпечні райони. Такі заходи дозволяють суттєво знизити кількість можливих людських жертв, особливо під час вчинення актів технологічного тероризму.

По-шосте, в окремих випадках після вчинення терористичного акту виникає потреба у введенні карантину, проведенні санітарно-протиепідемічних, ветеринарних та інших карантинних заходів. Такі заходи дозволяють запобігти розповсюдженню за межі району проведення антитерористичної операції різних захворювань.

По-сьоме, в районі проведення антитерористичної операції слід передбачити можливість введення обмежень або заборони продажу зброї, боєприпасів, спеціальних засобів, вибухових та отруйних речовин, встановлення особливого режиму обігу лікарських засобів і препаратів, що містять наркотичні засоби, психотропні або сильнодієві речовини, етиловий спирт, алкогольної та спиртовмісної продукції. Це пояснюється можливістю їх використання суб'єктами терористичної діяльності для поповнення свого арсеналу, а також підтримання відповідного психічного стану. Крім цього, такі заходи до того ж дозволяють обмежити випадки неадекватної поведінки 3 боку пересічних громадян [6, с. 154].

Заходи запобігання та припинення терористичної діяльності закріплені безпосередньо в Законі «Про боротьбу з тероризмом», а саме у ст. 15, як права осіб у районі проведення антитерористичної операції. Зокрема, до заходів запобігання порушенням антитерористичного законодавства можна навести:

- перевірка в громадян і посадових осіб документів, що посвідчують особу, а в разі відсутності документів - затримання їх для встановлення особи; 
- здійснення в районі проведення антитерористичної операції особистого огляду громадян, огляду речей, що при них знаходяться, транспортних засобів та речей, які ними перевозяться;

- тимчасове обмеження або заборона руху транспортних засобів і пішоходів на вулицях та дорогах, не допущення транспортних засобів, у тому числі транспортних засобів дипломатичних представництв і консульських установ, та громадян на окремі ділянки місцевості та об'єкти, виведення громадян з окремих ділянок місцевості та об'єктів, відбуксирування транспортних засобів.

Однією із основних проблем правового регулювання боротьби з терористичними виявами $є$ відсутність чіткої та налагодженої співпраці і взаємодії між спеціальними правоохоронними підрозділами щодо виявлення та документування організованої терористичної діяльності злочинних угруповань. Насамперед, Служба безпеки України, як головний суб'єкт антитерористичної діяльності в процесі здійснення оперативно-розшукової діяльності, спрямованої на виявлення терористично налаштованих осіб, як правило, не залучає інші служби до спільного виконання завдань. Коли в свою чергу постає питання про проведення в конкретному місці або районі антитерористичної операції, залучаються майже всі підрозділи в межах дислокації.

Також необхідно зауважити, що зміна характеру терористичної загрози в Україні дуже негативно позначилась на криміногенній ситуації.

Так, за даними Генеральної прокуратури України, за останні роки в Україні зареєстровано більше 4 тисяч кримінальних правопорушень, пов'язаних з терористичними актами.

Така ситуація вчинення терористичних злочинів не може не турбувати українське суспільство. Однак не менше занепокоєння викликають статистичні дані, які свідчать про існування відчутної різниці між кількістю зареєстрованих терористичних злочинів та кількістю проваджень за цими правопорушеннями, які були передані до суду. Так, протягом 2019 року за ст. 258 КК України було відкрито 426 проваджень, а надіслано до суду лише 40 проваджень [7]. 
Можна впевнено констатувати, що зусилля правоохоронних органів, спрямовані на розслідування терористичних актів, а також пов'язані з цим фінансові витрати, поки що не дають очікуваних результатів.

Практика застосування національного антитерористичного законодавства свідчить про недостатню ефективність діяльності органів досудового розслідування в кримінальних провадженнях щодо злочинів, передбачених статтями 258, 258-1, 258-2, 258-3, 258-4, 258-5 КК України. Причинами цього є:

1) незначна кількість фактів вияву терористичної діяльності в Україні до 2014 року. Тож за відсутності практики застосування відповідних положень Кримінального та Кримінального процесуального кодексів України співробітники правоохоронних органів нині лише набувають необхідних практичних навичок розслідування терористичних злочинів;

2) більшість кримінальних правопорушень вчинені на тимчасово непідконтрольній державній владі території України;

3) особи, які вчинили терористичні злочини, переховуються на окупованих територіях та за межами України, уникаючи таким чином кримінальної відповідальності;

4) відсутність у законодавстві України чіткого механізму визнання організації терористичною, що значно ускладнює процедуру притягнення осіб до кримінальної відповідальності за вчинення злочину, передбаченого статтею 258-3 КК України, а також негативно позначається на практиці застосування санкцій до осіб, які сприяють злочинній діяльності терористичних груп та терористичних організацій.

Серед чинників, які негативно позначаються на ефективності розслідування терористичних злочинів, чільне місце посідає недостатньо зважена та необгрунтована державна кримінальноправова політика, що протягом останніх кількох років почала поступово втрачати державницький характер, стаючи заручницею перманентних політичних протистоянь. Непоодинокими $є$ випадки безсистемних та науково не обгрунтованих змін окремих положень КК України.

Висновки. Підбиваючи підсумок, можна констатувати, що Україна в цілому створила необхідні законодавчі умови для за- 
безпечення успішної протидії тероризму, в тому числі в розрізі правового регулювання діяльності збройних формувань у зоні проведення антитерористичних операцій. Однак наведене вище певним чином знижує ефективність застосування положень антитерористичного законодавства та результативність діяльності правоохоронних органів у цій сфері. Це обумовлює необхідність пошуку рішень щодо вдосконалення вітчизняного антитерористичного законодавства.

\section{Список використаних джерел}

1. Актуальні питання протидії тероризму у світі та в Україні: аналіт. доповідь / О. О. Резнікова, А. О. Місюра, С. В. Дрьомов, К. С. Войтовський; за заг. ред. О. О. Резнікової. Київ: НІСД, 2017. 60 с.

2. Про боротьбу з тероризмом: Закон України від 20.03.2003 № 638-IV. URL: http://zakon4.rada.gov.ua/laws/show/638-15 (дата звернення: 25.04.2020).

3. Кримінальний кодекс України від 05.04.2011 № 2341-III. Вiдомості Верховної Ради України. 2001. № 25-26. Ст. 131.

4. Про Національну гвардію України: Закон України від 13.03.2014 № 876-VII. URL: http://zakon5.rada.gov.ua/laws/show/87618/print1443681029133806 (дата звернення: 25.04.2020).

5. Про запобігання та протидію легалізації (відмиванню) доходів, одержаних злочинним шляхом, фінансуванню тероризму та фінансуванню розповсюдження зброї масового знищення: Закон України від 14.10.2014 № 1702-IV. Відомості Верховної Ради Украӥни. 2014. № 50-51. Ст. 2057.

6. Трофімов С. А. Теоретико-правові засади антитерористичної діяльності. Вісник Харківського національного університету внутрішніх справ. 2012. № 1. С. 154-160.

7. Звіт Генеральної прокуратури України за 2019 рік. URL: https://old.gp.gov.ua/ua/statinfo.html (дата звернення: 25.04.2020).

Samofalov L., Samofalov O.

\section{PROBLEMS OF LEGAL REGULATION OF COMBATINIG TERRORISM AND PREVENTION OF TERRORIST ACTS}

The article addresses to the study of problematic issues of legal regulation of combating terrorism and the prevention of terrorist acts. The current state of crime prevention by terrorist groups is comprehensively analyzed. It is established that the range of subjects of anti-terrorist activity is not provided by the current legislation and the corresponding shortcomings that arise during the combating terrorism.

It is established that the legal basis for the fight against terrorism is the Constitution of Ukraine, the Criminal Code of Ukraine, the Law of Ukraine "On 
Combating Terrorism", other laws of Ukraine, the European Convention on the Suppression of Terrorism of 1977 year, the International Convention for the Suppression of Terrorist Bombings of 1997 year, the International Convention on the Fight against Terrorist Financing in 1999 year, other international treaties of Ukraine approved by the Verkhovna Rada of Ukraine, decrees of the President of Ukraine, resolutions and orders of the Cabinet of Ministers of Ukraine, as well as other regulations adopted to implement the laws of Ukraine.

Among the normative legal acts regulating relations in the field of counterterrorism, one of the prominent places has the Law of Ukraine "On Prevention and Counteraction to Legalization (Laundering) of the Proceeds of Crime, Terrorist Financing and Financial Proliferation of Weapons of Mass Destruction" dated 14 October, 2014.

It is proved that among the factors that negatively affect the effectiveness of the investigation of terrorist crimes, the leading place is taken by insufficiently balanced and unfounded state criminal law policy, which over the past few years has gradually lost its state character, becoming hostage to permanent political confrontation. There are many cases of unsystematic and scientifically unsubstantiated changes in certain provisions of the Criminal Code of Ukraine.

Key words: terrorism, terrorist act, terrorist operation, crimes, subjects, criminal liability.

\section{References}

1. Reznikova, O. O., Misiura, A. O., Driomov S. V., Voitovskyi, K. Ye. (2017), Current issues of counter-terrorism in the world and in Ukraine (Reznikova O.O. Ed.), NISD, Kyiv.

2. Ukraine (2003), On combating terrorism: Law of Ukraine, available at: (last accessed 25.04.2020).

3. Ukraine (2001), Criminal Code of Ukraine: Law of Ukraine, Verkhovna Rada of Ukraine, Kyiv.

4. Ukraine (2014), On the National Guard of Ukraine: Law of Ukraine, available at: http://zakon5.rada.gov.ua/laws/show/876-18/print 1443681029133806 (last accessed 25.04.2020).

5. Ukraine (2014), On Prevention and Counteraction to Legalization (Laundering) of the Proceeds of Crime, Terrorist Financing and Financial Proliferation of Weapons of Mass Destruction: Law of Ukraine, Verkhovna Rada of Ukraine, Kyiv.

6. Trofimov, S. A. (2012), "Theoretical and legal bases of anti-terrorist activity", Bulletin of Kharkiv National University of Internal Affairs, № 1, pp. 154-160.

7. Report of the Prosecutor General's Office of Ukraine for 2019, available at: https://old.gp.gov.ua/ua/statinfo.html (last accessed 25.04.2020). 


\section{ТЕОРІЯ I ПРАКТИКА \\ КРИМІНАЛЬНО-ПРОЦЕСУАЛЬНОЇ ДІЯЛЬНОСТІ ТА КРИМІНАЛІСТИКИ. ОПЕРАТИВНО-РОЗШУКОВА ДІЯЛЬНІСТЬ}

УДК 343.9

DOI 10.32755/sjlaw.2020.02.093

Леоненко О. А.,

старший викладач кафедри тактико-спеціальної підготовки, Академія Державної пенітенціарної служби, м. Чернігів, Україна ORCID: 0000-0002-9748-2469;

Ссипенко О. Г.,

старший викладач кафедри тактико-спеціальної підготовки, Академія Державної пенітенціарної служби, м. Чернігів, Україна ORCID: 0000-0002-3895-9079;

Рахільчук I. В., слухач магістратури, Академія Державної пенітенціарної служби, м. Чернігів, Україна

\section{СУЧАСНІ ПРАВОВІ ТА ОРГАНІЗАЦІЙНІ ЗАСАДИ РОЗВИТКУ СУДОВОЇ ЕКСПЕРТИЗИ ПІД ЧАС РОЗСЛІДУВАННЯ ЗЛОЧИНІВ}

Стаття присвячена проблемам використання судових експертиз та їх результатів на досудовому слідстві. Визначено перспективні напрямки розвитку криміналістики відповідно до ї̈ складових. Досліджено методи проведення судової експертизи в кримінальному судочинстві та вдосконалення їх за допомогою новітніх технологій, які використовують комп 'ютерні програми, такі як «Фоторобот», використання звуку та відео, поліграф, спектрограф тощьо для відтворення пам'яті людини та розвиток криміналістичних технологій, щу передбачає розроблення інформачійно-розшукових програм.

Ключові слова: криміналістика, теорія криміналістики, розслідування злочинів, криміналістичні засоби дослідження.

Постановка проблеми. На сучасному етапі наукові дослідження 3 криміналістики проводяться на кафедрах криміналістики вищих юридичних навчальних закладів, в науководослідних установах України, в тому числі: Науководослідному інституті проблем злочинності імені академіка B.В. Сташиса Національної академії правових наук; Державно- 
му науково-дослідному інституті Міністерства внутрішніх справ; Міжвідомчому науково-дослідному центрі боротьби 3 організованою злочинністю при Раді національної безпеки та оборони, Харківському центрі вивчення організованої злочинності, науково-дослідних експертних установах (Інститути судових експертиз Міністерства юстиції; Експертна служба Міністерства внутрішніх справ) та ін.

Відомо, що наукові рекомендації, спрямовані на протидію основних тенденцій сучасної злочинності, є ефективними. Такі галузі наукових знань, як криміналістика, кримінальний процес, слідча діяльність, кримінальне право, кримінологія повинні працювати, перш за все, на запобігання злочинності, розробляти сучасні рекомендації щодо розкриття вже вчинених, а також готувати пропозиції щодо передбачення злочинів як в близькому, так і в далекому майбутньому. Шепітько В. обгрунтовано пропонує розмежувати завдання криміналістики на два основні рівні: 1) завдання, спрямовані на вдосконалення теорії криміналістики; 2) завдання, спрямовані на вдосконалення правоохоронної практики [1, с. 25].

Аналіз останніх досліджень і публікацій. На основі досліджень визначено перспективні напрямки розвитку криміналістики відповідно до іiї складових. Щодо першого компонента, то перспективним є розроблення стратегічних напрямків його розвитку 3 урахуванням змін кримінального та кримінальнопроцесуального законодавства, досягнень науково-технічного прогресу і тенденцій розвитку світової криміналістики. Це стосується розроблення криміналістичної стратегії. А також потребує подальшого опрацювання та поглибленого вивчення питання визначення змісту та структури закономірностей злочинної діяльності, що входить до теми сучасної криміналістики та вдосконалення іï системи. Другий компонент криміналістики розвивається в напрямку впровадження інновацій в інформаційних, цифрових, телекомунікаційних технологій у правоохоронну діяльність; удосконалення та створення криміналістичних засобів дослідження звуку, електронних слідів, ДНК людини; адаптації новітнього обладнання для технічного та криміналістичного забезпечення слідчих дій. 
Мета статті полягає в дослідженні системи криміналістичних прийомів виявлення запису, вилучення, розслідування, оцінки та використання електронних доказів у кримінальному провадженні.

Виклад основного матеріалу. Сучасні дослідження в галузі криміналістичних технологій використовують комп'ютерні програми, такі як «Фоторобот», використання звуку та відео, поліграф, спектрограф тощо для відтворення пам'яті людини. Розвиток криміналістичних технологій передбачає розроблення інформаційно-розшукових програм, таких як Автоматизовані робочі місця (АРМ) для підрозділів досудового розслідування України, а також інших уповноважених на розслідування осіб, довідкових інформаційних програм. Автоматизовані робочі місця - це комплекси програмного та апаратного забезпечення, призначені для автоматизації завдань певного виду. Прикладами таких робочих станцій є: Робоче місце слідчого «Інсайт», робоче місце криміналістів різних експертних спеціальностей (трасолог, баліст, економіст, фоноскопіст, дослідження інтелектуальної власності тощо). Деякі 3 цих АРМ були розроблені в Національній академії внутрішніх справ - АРМ слідчого, АРМ експерта 3 тракологічних експертиз, АРМ працівника відділу боротьби 3 незаконним обігом наркотиків, а також авторської команди Національний юридичний університет імені Ярослава Мудрого та Інститут злочинності В. Сташиса - рука слідчого Інсайта. Актуальним $є$ поповнення криміналістичних записів такими новими видами, як фіксація райдужної оболонки, відеокомп'ютерне розпізнавання людини за зображенням, рентгенограма тулуба, геномні портрети [2, с. 37].

Ефективним у розслідуванні злочинів $є$ використання глобальних систем супутникового позиціонування (пристрої JPS), лазерних сканерів ZD під час проведення огляду місця події. Наприклад, пристрої JPS тепер можна використовувати під час огляду місця на відкритому повітрі, коли немає надійних орієнтирів. Невеликі електронні пристрої дозволяють швидко фіксувати географічні координати будь-якої точки, розташування предметів на місці події, відстань між ними. Крім того, науково-технічні засоби, що забезпечують всебічну фіксацію обста- 
новки на місці події з точним відображенням зовнішнього вигляду, форми, вимірювання відстані між предметами, кутів їх відносного розташування та розмірів 3 можливістю його вивчення безліч разів, це лазерні сканери ZD із відповідним програмним забезпеченням. Зокрема, це лазерний сканер DeltaSphere3D або Leica ScanStation, Z + F Imager із спеціально розробленим програмним забезпеченням для проведення дій.

Найголовнішим у розробленні криміналістичної тактики $є$ впровадження сучасних криміналістичних знань у слідчу та судову практику.

Сучасні реалії України вимагають від криміналістики вдосконалювати, розробляти та впроваджувати у правоохоронні практики слідчі прийоми: злочини, вчинені в надзвичайних ситуаціях; злочини проти основ національної безпеки України та військові злочини; організована злочинна діяльність; торгівля людьми; наркоманія; кіберзлочинність; незаконний обіг зброї та вибухових матеріалів; транснаціональна злочинна діяльність. Кримінально-інтеграційні аспекти євроінтеграції України найбільш яскраво відображаються в міжнародному співробітництві експертних установ України з європейською мережею судових та експертних установ (ENFSI). Ми розраховуємо на співпрацю в напрямку подальшої уніфікації, сертифікації та стандартизації як експертних методик, так і лабораторного обладнання. Крім того, наукові перспективи та можливості криміналістики розкриваються під час утворення та діяльності різних криміналістичних організацій, установ та наукових товариств, таких як: Товариство відбитків пальців (FPS), Міжнародна асоціація ідентифікації (IAI), Литовське товариство кримінологів, Польське товариство криміналістики, Міжнародний Конгрес кримінологів, що проводять світові та міжнародні наукові заходи (конференції, конгреси, симпозіуми) [1, с. 26].

Завдання криміналістики пов'язані 3 практичною криміналістичною діяльністю та зумовлені потребами правоохоронних органів для протидії сучасній злочинності, що, зокрема, пов'язане з реформою відомчої підготовки поліції в Україні. Таким чином, вирішення завдань реформування відомчої освіти, Міністерства внутрішніх справ, вимагає врахування досвіду, 
організації та функціонування національних систем поліції в інших європейських країнах та США. Американська модель характеризується впровадженням через навчальні заклади лише спеціальної поліцейської підготовки. Така освіта не визнається на рівні післядипломної освіти, що забезпечується винятково цивільними школами США. Натомість європейська модель орієнтована на створення власної відомчої системи освіти, що поєднує як поліцейську, так і загальну юридичну освіту. Іноді зустрічається поєднання особливостей як європейської, так і американської моделей (Хорватія, Угорщина та ін.) [3, с. 28]. Реалізація цих завдань на сучасному етапі також передбачає оптимізацію викладання криміналістики як дисципліни.

Ще одна тенденція розвитку криміналістики на сучасному етапі - консолідація наукових зусиль і співпраця вчених. Нині для проведення досліджень необхідні складні програми та залучення численних команд дослідників. Перспективним у цьому напрямку $є$ підготовка колективних монографій, посібників, підручників тощо. Почастішають комплексні дослідження, проведені колективами, до яких, крім криміналістики, входять фахівці різних галузей знань: фізіології та біоніки, кібернетики та математики, біології, хімії, антропології тощо. Звертаючись до Г. Малевського, В. Шепітько, вказує, що міжнародна співпраця кримінологів повинна базуватися не лише на «механічному» обміні інформацією, а й на спільних дослідженнях, «міжнародному розподілі праці» в криміналістичних дослідженнях, процесах конвергенції та інтеграції наукових теорій, концепцій, понять [1, с. 27].

Дактилоскопічний метод реєстрації злочинців успішно застосовується в правоохоронних органах усього світу понад 90 років i, ймовірно, буде використовуватися в майбутньому, оскільки сліди зразків папілярних візерунків рук людини завжди можна знайти на місці злочину та за їх допомогою встановити особу злочинця. Водночас злочинці за допомогою трансплантації, опіків, нанесення різних травм на долоні чи пальці або навіть їх ампутації намагаються уникнути кримінальної відповідальності. 
Крім дактилоскопічного методу реєстрації злочинців, завдяки розвитку кібернетики, сьогодні можна використовувати інші методи, такі як метод реєстрації за сітківкою ока та ДНК.

Метод реєстрації злочинців за схемою сітківки вперше було використано у 1924 році віденським судово-медичним лікарем Тюркелем. Після його знайомства з роботою офтальмологів, які в результаті багаторічних спостережень помітили різноманітні схеми сітківки і те, що вони не змінюються протягом усього життя людини [4, с. 914]. Окулісти змогли ідентифікувати людину, яка раніше була в них на прийомі, не за ознаками зовнішніх рис обличчя, а за відповідним очним захворюванням та малюнком сітківки. Але складністю на той час була відсутність належних засобів фіксації візерунків сітківки i, отже, неможливість впровадження цього методу ідентифікації. Сучасний стан розвитку криміналістичної техніки, інструментів та кібернетики в цілому, який успішно застосовується в криміналістиці, дає можливість використовувати схеми сітківки для реєстрації злочинців. Сучасні сканери дозволяють отримати високоякісні візерунки сітківки в кольорі, а комп'ютерні мережі швидко, локально та національно створювати подібні бази даних за умови під'єднання всіх абонентів (наприклад, обласних та районних міст) до єдиної комп'ютерної системи бази даних. Доступом до таких баз даних можуть користуватися всі суб'єкти системи i, якщо необхідно, оперативно використовувати базу даних комп'ютерної системи як для поповнення, так і для ідентифікації осіб на місцях.

Іншим напрямком криміналістичного обліку є створення баз даних ДНК. Перевага методу ідентифікації на основі ДНК перед усіма іншими методами полягає в тому, що не потрібно мати чіткі, наприклад, відбитки пальців або зразки крові для його використання. Оскільки ДНК присутня в кожній живій клітині людського організму, ії можна витягти з будь-якого зразка людської тканини або рідини. Західні експерти вважають, що навіть якщо підозрюваний не залишив слідів власної крові чи відбитків пальців, то його все одно можна визначити, знайшовши, наприклад, найменші сліди шкіри або волосся на місці злочину. Основним напрямком використання баз даних 
ДНК $є$ випадки розслідування тяжких злочинів проти людини, зокрема згвалтування. Наприклад, в Свропі є програма, що фінансується Європейським Союзом, боротьби із сексуальними злочинами. Однією з головних ліній цієї програми є створення в Європі інформаційної системи генетичних баз даних, в якій бере участь більшість європейських країн. Створення баз даних ДНК в Україні також можливе, наприклад, на базі Одеського обласного бюро судово-медичних експертиз - одного 3 провідних центрів судово-молекулярної генетичної експертизи, що проводиться в Україні з 1992 року. Для цього потрібна законодавча та фінансова підтримка галузі.

Новим кроком у криміналістиці найближчим часом стане використання технології «латентних відбитків пальців» (LTF), що значно спростить ідентифікацію злочинців. Це часткові відбитки пальців з поверхонь, які надзвичайно важко чи неможливо обробити (використані боєприпаси, зброя, ножі тощо). Для їх отримання використовують найновіші процеси хімічної, фізичної чи електронної обробки поверхонь.

Висновки. На сьогодні в розслідуванні кримінальних злочинів надзвичайно важливим $\epsilon$ ефективний огляд місця події, вилучення речових доказів та проведення судових експертиз. Необхідною умовою швидкого розкриття злочину під час досудового слідства $€$ виявлення і вилучення речових доказів для їх подальшого експертного вивчення. Використання новітніх досягнень криміналістичної технології у виявленні прихованих відбитків пальців та біологічних слідів людини є запорукою формування якісної доказової бази та ідентифікації конкретної особи під час досудового слідства.

\section{Список використаних джерел}

1. Сокуренко В. В. Сучасні тенденції розвитку кримінального процесу та криміналістики. Актуальні питання кримінального процесу, криміналістики та судової експертизи: матеріали міжвідом. наук.практ. конф. (м. Київ, 24 листоп. 2017 р.): у 2-х ч. Ч. 1. Київ, 2017. C. $25-27$.

2. Чернявський С. С. Основні концепти реформи системи освіти МВС України. Світовий досвід підготовки кадрів поліиії та його впровадження в Украӥні: матеріали міжнар. наук.-практ. конф. (м. Дніпропетровськ, 17 берез. 2016 р.). 2016. С. 37-40. 
3. Перепечина И. О. ДНК в вопросах и ответах: Об исследовании ДНК в судебной медицине и криминалистике. Москва, 1999. 58 с.

4. Маланчук П. М. Перспективи розвитку криміналістичної техніки в розслідуванні, розкритті і попередженні злочинів. Молодий вчений. 2017. № 11. С. 914-918.

\section{Leonenko O., Yesypenko O., Rakhilchuk I. MODERN LEGAL AND ORGANIZATIONAL PRINCIPLES FOR THE DEVELOPMENT OF JUDICIAL EXAMINATION IN CRIME INVESTIGATION}

The scientific article is devoted to the problems of using forensic examinations and their results in the pre-trial investigation. Perspective directions of development of criminology according to its components are defined. The current state of development of forensic technology, tools and cybernetics in general, which is successfully used in forensics makes it possible to use retinal schemes to register criminals.

It is noted that the development of forensic technologies involves the development of information retrieval programs, such as Automated Workplaces (AWP) for pre-trial investigation units of Ukraine, as well as other persons authorized to investigate, reference information programs.

It is effective to use global satellite positioning systems (JPS devices) while investigating crimes, ZD laser scanners when inspecting the scene, as small electronic devices allow you to capture the geographical coordinates of any point, location of objects at the scene, the distance between them rather quickly.

A new step in forensics in the near future will be the use of "latent fingerprint" (LTF) technology, which will greatly simplify the identification of criminals.

Methods of forensic examination in criminal proceedings and their improvement using the latest technologies that use computer programs such as "Photorobot", the use of audio and video, polygraph, spectrograph, etc. to reproduce human memory and the development of forensic technology, which involves development of information retrieval programs.

These new approaches and knowledge used by forensics are a necessary condition for the rapid detection of the crime, detection and seizure of physical evidence for their further expert studying.

The use of the latest achievements of forensic technology in the detection of hidden traces is the key to the formation of a quality evidence base and identification of a particular person during the pre-trial investigation.

Key words: forensics, forensics theory, crime investigation, criminological means of research.

\section{References}

1. Sokurenko, V. V. (2017), Current trends in the development of the criminal process and criminalistics. Relevant nutrition of the criminal process, criminalistics and ship expertise: materials of the scientific and practical conference (November 24, 2017), Vol. 2, Part. 1, Kyiv, pp. 25-27. 
2. Cherniavskyi, S. S. (2016), Basic concepts of reforming the education system of the Ministry of Foreign Affairs of Ukraine, Holy news of the preparation of personnel in the police and in Ukraine: materials of the interdepartmental scientific and practical conference (March 17, 2016), Dnipro, pp. 37-40.

3. Perepechina, I. O. (1999), DNA in questions and answers: On the study of DNA in forensic medicine and forensic science. Moscow.

4. Malanchuk, P. M. (2017), "Prospects for the development of forensic technology in crime investigating, crime solving and crime preventing", Young scholar, No. 11, pp. 914-918. 


\section{ВITACMO 3 70-річчям!}

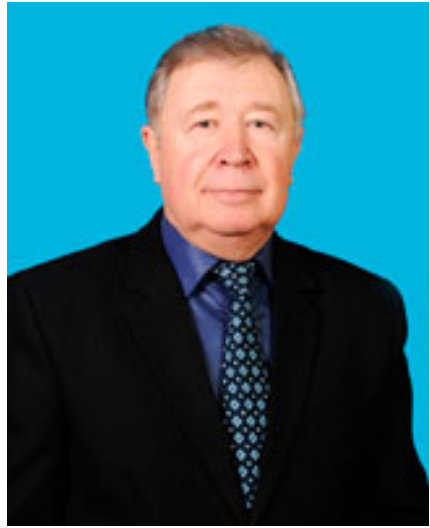

Шановний Леоніде Прохоровичу! Прийміть найщиріші вітання та найкращі побажання з нагоди Вашого славного 70-річного ювілею! У різні часи на різних посадах Ви неодноразово доводили свій високий професіоналізм, а Ваш внесок у юридичну науку $\epsilon$ тим добром, яке слугуватиме орієнтиром для нових поколінь правоохоронців. Академії пощастило, що в іiї колективі працює такий досвідчений учений, душевна і щира людина, мудрий наставник і справжній лідер. Ви $є$ прикладом сумлінного ставлення до своїх обов'язків. Ваша нелегка служба в органах внутрішніх справ дала можливість набути досвід, який у поєднанні з науковою діяльністю зробив Вас одним із унікальних викладачів, здатним зацікавити молодь своїми знаннями та життєвою мудрістю. Хай кожен день стане успішним, доля прихильною до Вас і Ваших рідних. Бажаю Вам здоров'я, життєвої сили та енергії!

3 повагою Олексій Михайлович Тогочинський, ректор Академії ДПтС

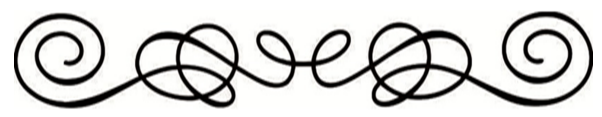

Шановний Леоніде Прохоровичу! У день Вашого народження мені дуже приємно привітати Вас з ювілеєм як прекрасного колегу, хорошого наставника та справжнього фахівця своєї справи. Ваша освіченість, компетентність і небайдужість $є$ складовими Вашого успіху та авторитету. Уже багато років Ви щоденно докладаєте зусилля, щоб Академія розвивалася, продовжуєте традиції, що формують славетну історію нашого закладу вищої освіти. Ваша постійна наполеглива праця, творчий пошук дають можливість готувати конкурентоспроможних фахівців - наших випускників. Тож нехай любов і повага Ваших рідних, людей, які Вас оточують, Ваша висока відданість справі стануть запорукою нових здобутків, здійснення всіх світлих мрій та сподівань. Бажаю, щоб Вам повсякчас таланило на однодумців, щирих і порядних людей, які додаватимуть наснаги, а накопичений Вами життєвий досвід і мудрість допомагали досягати нових ви- 
сот. Земних Вам щедрот та міцного здоров’я, гарного настрою, миру та ладу у Вашій родині і домі!

3 повагою Олександр Іванович Олійник, периий проректор Академї ДПтС

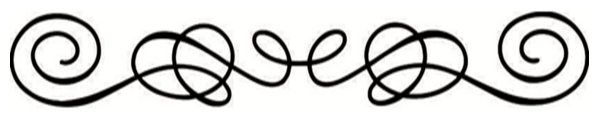

Шановний Леоніде Прохоровичу! Від щирого серця вітаю Вас із 70-річчям, з ювілеєм, який дозволяє озирнутися й подивитися на здобутки, чимало пригадати й визнати, що прожиті роки дали мудрість, любов і повагу людей, з якими Ви зустрічалися в житті, 3 якими довелось служити та працювати, в кого вчились і кого навчали та виховували. Ваше життя є яскравим прикладом чесного та сумлінного служіння Батьківщині, високої відповідальності за справу, енергійності та наполегливості. Знаю Вас як оптиміста, людину творчу та енергійну, справедливу і небайдужу, наділену гострим розумом та багатьма визначними талантами, як знаного науковця, вченого-юриста, який передає молоді неоціненний скарб знань та духовності. Бажаю Вам здоров'я, успіхів у всіх життєвих справах, довголіття, сімейного добробуту і сімейного затишку, наснаги. Нехай Вам таланить на вірних друзів, i Ваше життя буде наповнене новими звершеннями, а життєвих сил вистачить для реалізації найсміливіших планів і задумів!

3 повагою Станіслав Олегович Чебоненко, проректор Академії ДПтС

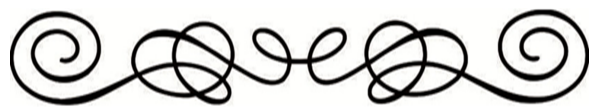

Шановний Леоніде Прохоровичу! Ви - мудрий педагог і наставник, величний у творчому науковому горінні, гідний взірець майстерності. Ваша сумлінна праця, бездоганний авторитет і активна життєва позиція привнесли вагому частку в розвиток і процвітання нашої Академіі. Нехай неодмінно збуваються всі Ваші задуми, а творча енергія і професіоналізм будуть винагороджені вдячністю та повагою людей! Щоб добробут та злагода, пошана й турбота близьких, друзів, колег супроводжували і підтримували в житті. Здоров'я на довгі роки, оптимізму та здійснення найсміливіших бажань.

У день Вашого славетного ювілею з найщчирішими вітаннями Лариса Петрівна Шумна, завідувач кафедри теорії та історії держави і права, конституційного права Академї ДПтС та колектив кафедри 


\section{НАУКОВИЙ ВІСНИК СІВЕРЩИНИ. СЕРІЯ: ПРАВО}

\section{НАУКОВИЙ ЖУРНАЛ}

№ 2 (10)

Відповідальний за випуск

Коректор

Комп'ютерна верстка і макетування
Сикал М. М.

Сила Л. М.

Олефіренко В. М.

За достовірність інформації в статтях відповідальність несуть автори публікацій.

Підписано до друку 02.12.2020 р. Формат 60×84/16.

Друк різографія. Гарнітура Times New Roman. Ум. друк. арк. 6.05. Тираж 100 пр. Зам. № 51/20.

Редакційно-видавнича група Академії Державної пенітенціарної служби 14000, м. Чернігів, вул. Гонча, 34.

Свідоцтво про внесення суб'єкта видавничої справи до Державного реєстру видавців, виготовлювачів і розповсюджувачів видавничої продукції серія ДК № 5378 від 06.07.2017 р. 